\title{
On the pathogenesis of endometriosis
}

Citation for published version (APA):

van der Linden, P. J. Q. (1995). On the pathogenesis of endometriosis. [Doctoral Thesis, Maastricht University]. Datawyse / Universitaire Pers Maastricht. https://doi.org/10.26481/dis.19951130pl

Document status and date:

Published: 01/01/1995

DOI:

10.26481/dis.19951130pl

Document Version:

Publisher's PDF, also known as Version of record

\section{Please check the document version of this publication:}

- A submitted manuscript is the version of the article upon submission and before peer-review. There can be important differences between the submitted version and the official published version of record.

People interested in the research are advised to contact the author for the final version of the publication, or visit the DOI to the publisher's website.

- The final author version and the galley proof are versions of the publication after peer review.

- The final published version features the final layout of the paper including the volume, issue and page numbers.

Link to publication

\footnotetext{
General rights rights.

- You may freely distribute the URL identifying the publication in the public portal. please follow below link for the End User Agreement:

www.umlib.nl/taverne-license

Take down policy

If you believe that this document breaches copyright please contact us at:

repository@maastrichtuniversity.nl

providing details and we will investigate your claim.
}

Copyright and moral rights for the publications made accessible in the public portal are retained by the authors and/or other copyright owners and it is a condition of accessing publications that users recognise and abide by the legal requirements associated with these

- Users may download and print one copy of any publication from the public portal for the purpose of private study or research.

- You may not further distribute the material or use it for any profit-making activity or commercial gain

If the publication is distributed under the terms of Article $25 \mathrm{fa}$ of the Dutch Copyright Act, indicated by the "Taverne" license above, 
On the Pathogenesis of Endometriosis 


\section{CIP-GEGEVENS KONINKLIJKE BIBLIOTHEEK, DEN HAAG}

Lifnden, Paul Jan Quirien van der

On the pathogenesis of endometriosis / Paul Jan Quirien van der Linden. - Maastricht : Universitaire Pers

Maastricht. - Ill.

Proefschrift Rijksuniversiteit Limburg Maasticht. - Met lit. opg. - Met samenvatting in het Nederlands.

ISBN 90-5278-199-0

Trefw.: endometriose / pathogenese / celadhesie. 


\title{
On the Pathogenesis of Endometriosis
}

\author{
Proefschrift
}

ter verkrijging van de graad van doctor aan de Rijksuniversiteit Limburg te Maastricht, op gezag van de Rector Magnificus, Prof. mr M.J. Cohen, volgens het besluit van het College van Dekanen, in het openbaar te verdedigen op donderdag 30 november 1995 om 14.00 uur

$$
\text { door }
$$

Paul Jan Quirien van der Linden

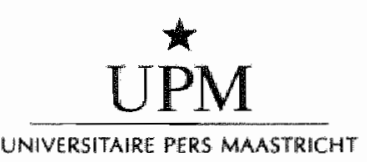




\section{Promotor:}

Prof. dr J.L.H. Evers

\section{Co-promotores:}

Dr A.F.P.M. de Goeij

Dr G.A.J. Dunselman

\section{Beoordelingscommissie:}

Prof. dr J.W. Arends (voorzitter)

Prof. dr I.A. Brosens (Universiteit van Leuven)

Prof. dr A.P.M. Heintz (Universiteit Utrecht)

Prof. dr H.F.P. Hillen

Prof, dr F.C.S. Ramaekers 
Aan Mirjam en Joep 



\section{Contents}

\section{Chapter 1}

General introduction

\section{Chapter 2}

Aims of the study

\section{Chapter 3}

Epithelial cells in peritoneal fluid: of endometrial origin?

\section{Chapter 4}

Expression of integrins and E-cadherin in cells from menstrual effluent, endometrium, peritoneal fluid, peritoneum and endometriosis . . . . . . . . . . . . . . . . . . . . . . . . 45

\section{Chapter 5}

P-cadherin expression in human endometrium and endometriosis

\section{Chapter 6}

Expression of cadherins and integrins in human endometrium throughout the menstrual cycle

\section{Chapter 7}

Amniotic membrane as an in vitro model for endometrium-extracellular matrix interactions

\section{Chapter 8}

Endometrial cell adhesion in an in vitro model using intact amniotic membranes 


\section{Chapter 9}

General discussion

Summary ................................. 107

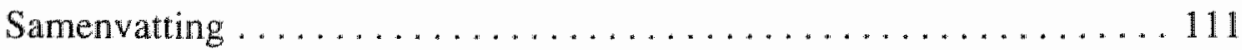

Curriculum vitae $\ldots \ldots \ldots \ldots \ldots \ldots \ldots \ldots \ldots \ldots \ldots \ldots \ldots \ldots$

List of publications $\ldots \ldots \ldots \ldots \ldots \ldots \ldots \ldots \ldots \ldots \ldots \ldots \ldots \ldots$

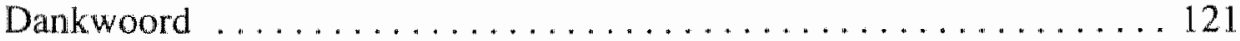




\section{Chapter 1}

\section{General introduction}

Part of this chapter will be published as Theories on the pathogenesis of endometriosis in Human Reproduction 
Endometriosis is the presence of functional endometrial glands and stroma in ectopic locations outside the uterine cavity. Although endometriosis is one of the most commonly encountered problems in gynecology, its pathogenesis is still poorly understood and remains controversial.

The first histological description of a lesion consistent with endometriosis was given by Von Rokitansky (1) in 1860. Already in 1896, Cullen $(2,3)$ suggested that endometriomas, or adenomyomas as he called these lesions, resembled the mucous membrane of the uterus. Among the theories concerning the pathogenesis of endometriosis three main concepts can be discerned (table 1). The oldest concept -in situ development- is that endometriosis has developed on the spot where it is identified. Development may occur from the remnants of the ducts of Wolff or the ducts of Müller, or alternatively from metaplasia of the peritoneal or ovarian tissue $(4,5)$.

A second concept the induction theory-is based on the assumption that endometriosis results from differentation of mesenchymal cells, activated (in-

\section{Table 1}

Theories on the pathogenesis of endometriosis (modified from Ridley (4) and Hingst (42)).

1. In situ development

a. Germinal epithelium of the ovary (Waldeyer, 1870)

b. Embryonic cell rests

- Mesonephric (Wolffian knob, Wolffian duct) (Von Recklinghausen, 1895 , Breus, 1894)

- Paramesonephric (Müllerian ducts) (Cullen, 1896, Russell, 1899)

c. Coelorinc metaplasia (Iwanoff, 1898, Meyer, 1903, Lauche, 1923)

d. Metaplasia by inflammation (Hueter, 1918, Meyer, 1919, Tobler, 1923)

c. Metaplasta by hormonal stimulation (Novak, 1931)

f. Metaplasia by induction (omnipotent blastema) (Levander, 1941, Merril, 1966)

g. Secondary Müllerian system (Lauchlan, 1972)

2. Transplantation

a. Implantation, retrograde menstruation (Sampson, 1921)

b. Implantation, mechanical transplantation (Greenhill, 1942)

c. Benign lymphogenous metastasis (hystero-adenosis metastatica)

(Halban, 1924/1925, Javert, 1949)

3. Combination of in situ development and endometrial transplantation and implantation 
duced) by substances released by degenerating endometrium that arrives in the abdominal cavity $(6,7)$.

A third concept -the transplantation or implantation theory- is based on the transplantation and subsequent implantation of endometrial tissue $(8,9)$. This would include transportation of viable endometrial cells during menstruation via the fallopian tubes into the abdominal cavity, implantation of these cells onto the peritoneum and the development of these cells into endometriosis.

\section{In-situ development}

Von Recklinghausen offered several arguments in support of endometriosis originating from the Wolffian duct, or better the Wolffian knob. He noted a great similarity in the structure of "adenomyomas" and the mesonephros and emphasized that the mesonephros develops close to the uterus, the tubes and the ovaries. Others did not consider the mesonephros itself but its duct (Wolffian duct) as the tissue of origin for endometriosis. In particular Meyer (10) disputed the theories of von Recklinghausen. He did not find these similarities between endometriomas and the mesonephros and did not see any "organ-ähnlichen $B a u^{\prime}$. Furthermore, a tumor originating from an organ that is segmentally present in the embryo, would not keep a similar shape during later developmental stages. Meyer also considered the location of the mesonephros not in accordance with the sites the tumors were found. Russell (11) surmised endometriosis to arise from Müllerian (paramesonephric) tissue. There are two major objections against Russells theory. Firstly endometriosis is found in a much wider area than that of the course of the Müllerian ducts, and secondly endometriosis is not present in embryonic remnants of the Müllerian ducts in males. The theory that endometriosis originated from an embryonic organ has not been met with much opposition, during the time that endometriosis was found only either in the uterine wall or in the fallopian tubes and direct surroundings. Subsequently, however, endometriosis was recognized in the colon, the small intestines, the appendix and in scars of the abdominal wall. These findings rendered a purely embryonic derivation too restrictive. Lauche (12) was one of the first to explain the development of endometriosis from a single origin, no matter where it developed. He deduced a common origin for different spots of endometriosis from the strict resemblance in histologic morphology of these lesions. Endometriosis was supposed only to develop where peritoneum was found. According to this theory, that was already suggested by Iwanoff (13) and later was followed by Meyer (14) and Lauche (12), the histogenesis of endometriosis is explained by metaplasia of the original coelomic membrane. These metaplastic changes could occur secondary to inflammatory processes or hormonal influences $(15,16)$. 
The theory of coelomic metaplasia has still some support, because it can explain the origin of endometriosis, regardless of the sites or the conditions of its occurrence (17). Indeed, there is some circumstantial evidence in case reports of endometriosis occurring in young girls, even before menstruation, and in reports of endometriosis at rare locallisations, such as pleura or diaphragm. The theory does not explain why endometriosis occurs exclusively in women, and preferably during the reproductive years, or why endometriosis mainly affects the pelvic organs, or why it only occurs in women with functioning endometrium. Therefore, proof of this theory is lacking, either experimentally or clinically.

\section{The induction theory}

Levander (6) has introduced the induction theory. This theory is based on the assumption that specific substances which are released by degenerating endometrium induce the development of endometriosis from omnipotent blastema, present in connective tissue. Merrill (7) implanted filters that contained viable and ischemic endometrial tissue subperitoneally in the rabbit. The suggestion was made that cell-free endometrial products were capable of inducing endometrial metaplasia. These changes do not meet the criteria for endometriosis, since no endometrial stroma was found in the experiments that were reported so far.

Lauchlan (5) introduced the term "secondary Müllerian system", that refers to all Müllerian type epithelium located outside the course of the original Müllerian ducts. In his theory the secondary Müllerian system is composed of those cells similar to or identical with those lining the oviducts, uterus and endocervix. This layer of cells could then, in particular on the surface of the ovary, through metaplasia develop into four cell types, one of which endometrium-like. This could occur before or after invagination. One argument in favor of this theory is that endometriosis is not a simple ectopic focus of pure endometrium, because both serous and mucinous epithelium can be found in endometriotic lesions (5).

\section{The implantation theory}

The conditions that have to be met for the implantation theory are threefold, firstly, retrograde menstruation has to occur, secondly, retrograde menstruation should contain viable endometrial cells, and, thirdly, adhesion to the peritoneum has to occur with subsequent implantation and proliferation. The implantation theory was originally neglected for a long time, because menstrual effluent was 
considered to contain only non-viable endometrial tissue and retrograde menstruation was thought to be a rare phenomenon $(14,18)$. Although the theoretical concept was recognized by some authors, the problem remained to explain extraperitoneal localisations of endometriosis $(19,20)$.

Retrograde menstruation and peritoneal adhesion of endometrial tissue is an essential element in the pathogenesis of endometriosis according to Sampson"s theory $(8,9,21)$. Sampson realized that for his concept the viability of endometrial tissue retrogradely shed into the peritoneal cavity was crucial, or as he stated: "If bits of Müllerian mucosa carried by menstrual blood escaping into the peritoneal cavity are always dead, the implantation theory, as presented by me, also is dead and should be buried and forgotten" (9).

\section{Viability}

Menstrual effluent contains viable endometrial cells as shown in the classical study of Keettel and Stein (22) in 1951. They were able to culture cells from passively collected menstrual effluent. Only in 2 of 7 cases sufficient material was obtained for culturing. After 24 hours outgrowth of cells was noted. The cells were either fibroblastic or epithelioid. Cron and Gey (23) had tried earlier to prove the viability of cast-off menstrual endometrium in culture, but they had used a curette to remove the endometrium. Already Geist (24) had suggested that desquamation of endometrium was not due to local necrosis, because he could demonstrate that menstrual effluent contained viable endometrial cells, that remained alive for at least one hour. Ridley and Edwards (25) demonstrated in 1958 that endometrial cells obtained from the menstrual effluent could be implanted into the abdominal wall fascia. They selected 53 patients that were suitable for their experiments and of these 21 agreed to participate in the study. Only 8 were actually included. An aliquot of shed endometrium was injected onto the abdominal fascia of these 8 patients prior to an abdominal operation a few weeks later. Only in one case evidence was found for endometriosis developing at the site of injection.

The phenomenon of menstruation itself is something that has puzzled man for a long time. Menstrual effluent is composed of blood elements, endometrial cells and extracellular fluid. Menstruation is almost unique to woman and a few other primates. So far only two nonprimate species have been shown to menstruate naturally i.e. the elephant shrew (elephantulus myuras jamesoni) and one bat (glossophaga soricina) $(26,27)$. The uterine cycle of this bat is terminated by true menstruation, i.e. extensive necrosis and desquamation of a large part of the lamina functionalis with associated bleeding. The timing of this process is quite 
unusual. Menstruation can be observed both immediately before and after ovulation in this bat (27).

The reasons for the shedding of endometrium during menstruation in women remain unclear. Most important seems to be that during the menstrual cycle the human endometrium develops into a more differentiated stage in the preparation of the endometrium for implantation than does the endometrium of nonmenstruating species. Consequently, when cells have become too differentiated, in order to perform a specific function, it is impossible to revert to their less differentiated state and therefore these cells will have to be discarded (28). This fundamental difference between the menstrual and oestrus cycles is presumably the basic reason for the bleeding and breakdown of tissue at menstruation. The menstruation occurs because the preparation of the endometrium has surpassed the point of return to its inactive state without massive degeneration and bleeding.

\section{Retrograde menstruation}

After Sampson (8), Watkins (29) reported the occurrence of blood dripping from one or both fallopian tubes, when a laparotomy was performed during menstruation. He detected red blood cells, leukocytes and endometrial cells in all specimens, whereas glandular structures were found in samples from 2 of 8 patients. The presence of blood in peritoneal fluid has been reported $(30,31)$. Passage and transfer of endometrial fragments to the peritoneal cavity through the fallopian tubes also has become apparent from studies by Beyth and coworkers (32). Peritoneal fluid contains endometrial tissue in up to $59 \%$ of patients with and without endometriosis undergoing laparoscopy at various stages of the menstrual cycle (33-37). Recently, Kruitwagen and coworkers (35) have found viable endometrial cells in peritoneal fluid. These authors succeeded in culturing these cells in vitro, and their data strongly suggest an endometrial origin of epithelial cells in peritoneal fluid. Furthermore, the anatomic distribution of endometriosis correlates very well with principles of transplant biology (38). Blumenkrantz and coworkers (30) observed blood-stained peritoneal fluid during menses in women undergoing chronic peritoneal dialysis. In these women, blood staining of peritoneal fluid preceded vaginal bleeding for one to several days. The presence of blood was detected by the observation of threads of sedimented red blood cells. The presence of endometrial tissue was not reported. Halme and coworkers (31) found a red color in $90 \%$ in the peritoneal fluid samples of women with patent tubes, suggesting the presence of blood. Only visual documentation of the color of the peritoneal fluid samples was carried out. Oosterlynck and coworkers (39) noted that peritoneal fluid of women with endometriosis was bloodstained more frequently than peritoneal 
fluid from women without endometriosis. The samples, however, were obtained at different phases of the menstrual cycle.

Reti and coworkers (40) suggested that the demonstration of blood in the pouch of Douglas at laparoscopy was inadequate for the demonstration of retrograde menstruation since in their study only a weak correlation was found between blood staining of peritoneal fluid and the presence of endometrial cells. The presence of small clusters of cells resembling endometrial glands and stroma in the smear made from peritoneal fluid and stained according to Papanicolaou was taken as evidence for their endometrial origin by these authors.

Demonstration of the presence of endometrial cells in peritoneal fluid is an objective way to assess retrograde menstruation. Bartosik and coworkers (33) reported no significant difference in the presence of endometrial tissue in peritoneal fluid between patients with and patients without endometriosis. In 6 of 32 patients with endometriosis and in 1 of 9 patients without endometriosis, they were able to show endometrial tissue in peritoneal fluid. Badawy and coworkers (36) described an increased prevalence of endometrial tissue in peritoneal fluid from patients with endometriosis. Their control group consisted mainly of patients with tubal factors, which may have biased their results. Furthermore, these authors did not correlate the presence of endometrial cells with the phase of the menstrual cycle. Endometrial glands have been reported to occur in the peritoneal cavity after dilatation and curettage and after uterotubal irrigation $(32,33,39,41)$. Beyth and coworkers (32) demonstrated that endometrial cells and tissue fragments could be found in a high percentage in the peritoneal cavity after flushing of the uterus and the tubes or after dilatation and curettage, irrespective of the phase of the cycle. In 12 of 21 patients they found evidence of the presence of endometrial tissue in the peritoneal cavity before curettage. Willemsen and coworkers (41) described the presence of proliferating endometrial epithelial cells in $67 \%$ of cultures prepared from peritoneal fluid obtained after uterotubal irrigation. Koninckx and coworkers (37) found that endometrial tissue was more often refluxed into the peritoneal cavity after uterine irrigation in women with endometriosis as compared to women without endometriosis.

Most studies demonstrated the presence of endometrial cells in peritoneal fluid, using Papanicolaou staining $(36,37,40)$. This has the disadvantage that only rather large clusters of cells, resembling endometrial glandular and stromal tissue, can be used for recognition and not single cells. Although epithelial markers could be demonstrated in cells of menstrual effluent, endometrium, peritoneal fluid as well as in endometriotic lesions, this is no strict evidence that endometriosis originates from endometrium by retrograde shedding of viable tissue fragments. 
As yet, the reason for implantation of endometrial tissue on the peritoneum or in other regions is unclear. Also the question how retrogradely shed endometrium can adhere to the peritoneal wall is still unanswered. In particular, studies on the initial contact between just one or a couple of endometrial cells and the peritoneal lining are still lacking. If retrograde menstruation is important in the pathogenesis of endometriosis, then at some point in time endometrial tissue, either glands or stroma, should adhere to the peritoneum. In theory, either the glandular epithelial cells or stromal cells or both cell types are directly involved in the contact with the epithelium of the peritoneum. Alternatively, both cell types are mutually influencing each other to allow this first contact. Another possibility could be direct contact of endometrial cells with the extracellular matrix. Both implantation of viable endometrial tissue fragments and induction of coelomic metaplasia by these fragments will require adhesion of endometrial cells to the peritoneal lining. It is relevant therefore to study the mechanisms of cell adhesion in the development of endometriosis.

In conclusion, the transplantation theory, that suggests implantation and subsequent growth of retrogradely shed viable endometrial cells, still remains the most widely accepted theory to explain the pathogenesis of endometriosis. A plausible alternative could well be the induction theory, including transformation of mesothelium to endometrium-like tissue induced by products of regurgitated endometrium. In both theories retrograde menstruation and adhesion of shed endometrial cells to the peritoneal lining is required.

\section{Cell adhesion}

An important property of cells that allows them to form tissues, is their intrinsic adhesiveness. Multicellular organisms cannot exist without the association of cells, owing their orderly structure to their tight intercellular adhesion (43). Cell-cell adhesion is involved in organogenesis, physical transport, signal transmission and immunological function in multicellular organisms. Cells usually form contacts through specialized membrane domains. In general, two major classes of adhesion can be distinguished, i.e. cell-cell and cell-extracellular matrix adhesion (44). Cell adhesion molecules (CAMs) are cell surface glycoproteins that are crucial in morphogenesis, histogenesis, and in defining discrete borders between cell populations. A number of cell surface glycoproteins have been identified as intercellular adhesion molecules. These CAMs required for cell adhesion are classified into several classes: cadherins, integrins, and the lectin-like glycoproteins including the immunoglobulin superfamily and selectins (45). CAMs are operationally classified into molecules which are $\mathrm{Ca}^{2+}$-indepent and molecules which require $\mathrm{Ca}^{2+}$ for their binding activity $(46,47)$. 


\section{Lectin-like proteins}

The immunoglobulin superfamily consists of a wide variety of molecules that share a common structural feature, the immunoglobulin homology unit, consisting of 70 to 110 amino acids organized in 7 to $9 \beta$-pleated sheets. The adhesion molecules of the immunoglobulin superfamily are involved in cell-cell adhesion and are especially important during embryogenesis, woundhealing, and the inflammatory process.

The selectin family of cell adhesion molecules consists of CAMs sharing an overall structure with a composite of three distinct regions; a lectin-like domain, a domain with homology to epidermal growth factor, and a domain with homology to certain complement regulatory proteins (45). Functionally they mediate heterotypic interactions between or among blood cells and endothelial cells during lymphocyte homing and leukocyte adhesion. Their role in other tissues, if any, is still not well established. The lectin-like proteins will not be discussed in further detail here.

\section{Cadherins}

Cadherins belong to a group of calcium-dependent transmembrane glycoproteins $(43,48,49,50)$. Cadherins mediate cell-cell interactions. Adhering processes, which involve cadherins are homophylic: cells adhere preferentially to cells which express the same cadherin (51). Expression of cadherins changes dynamically during development, but cadherins are stably expressed in normally developed tissues throughout the cell cycle (49). Cadherins are important constituents of adherens junctions (zonula adherens) where they are responsible for cytoskeletal organization. The firstly detected member of the cadherin gene family was termed uvomorulin since it was identified during early mouse development where it mediates the compaction process at the morula stage (52). Furthermore it is involved in the aggregation of embryonal carcinoma (53). If $\mathrm{Ca}^{2+}$ is removed from the extracellular environment, the cell-cell connections that involve cadherins become loose. Antibodies to cadherins can mimic this effect of calcium depletion. If antibodies are added to monolayers of epithelial cells in culture, the cell-cell adhesion is disrupted and consequently cells become unable to maintain epithelial sheets (54). The structure of calcium dependent cell adhesion molecules of different cell types is heterogenous in biochemistry. Three of these cadherins share a basic structure and are well characterized at the molecular level i.e. E-cadherin (epithelial), $\mathrm{N}$-cadherin (neural), and P-cadherin (placental) $(49,55,56)$. Additional subclasses have subsequently been characterized $(49,57)$. Each cadherin type has a unique but wide tissue distribution that may vary during different stages of development. In many types of cells, 
multiple cadherin subclasses are co-expressed in varying combinations. Analysis of protein and DNA sequences revealed that different cadherins have a great resemblance in their primary structures. They consist of 723 to 748 amino acids, and have a single transmembrane domain that divides the molecules into an amino-terminal extracellular and a carboxy-terminal cytoplasmic domain. The molecules are identical in $43-58 \%$ of the amino acid sequence. The best conserved region is the cytoplasmic domain, which regulates the cell-cell binding function of the extracellular domain (58). The cell binding activity of cadherins depends on their association with some specific proteins and actin based cytoskeleton (catenins). The extracellular part that mediates the selective cell adhesiveness is composed of three repeating domains, each with two putative $\mathrm{Ca}^{2+}$ binding motifs (59). Inhibition of the cadherin activity with antibodies induces dissociation of cell layers, which indicates the fundamental importance of these molecules in maintaining multicellular structures (49). When a cell layer is being separated into two cell layers during embryogenesis, cells of either layer express a new cadherin subclass or lose the originally expressed cadherin. When a cell group is developmentally scheduled to be connected with other cell groups, they both express identical cadherins (43). Cells expressing cell adhesion molecules of different specificity or different levels of the same cell adhesion molecule tend to segregate in vitro (60). Cell sorting-out depends upon both the specificity and the number of cell adhesion molecules expressed at the cell surface (61). Generally, one or two types of cadherins are expressed in a cell and the combination differs with the cell type. Since other unidentified types of cadherins may exist, each cell might express more complex combinations of different cadherins than known at present.

E-cadherin (also known as uvomorulin or cell-CAM 120/80 and nearly homologous to L-CAM in the chicken and Arc-1 in the dog) is expressed in all proliferating epithelial cells derived from the ectoderm and the entoderm. Neural and mesodermal tissues do not express E-cadherin, with the exception of some components of the urogenital system, such as mesonephric and metanephric tubules and some mesothelial layers $(50,62,63,64)$. E-cadherin is widely detected in epithelial cells from all genital organs at cell-cell borders. E-cadherin is expressed at the cell to cell boundaries of the endometrium $(50,62)$. It is also found in glandular cells of the cervix, endometrium and fallopian tube, but ovarian tissues are negative, except for germinal epithelium.

P-cadherin was first identified in mouse placental tissue as a connecting molecule between the embryo and the uterine wall $(65,66)$. In the mouse, P-cadherin is also expressed in the mesothelium, as well as in the epidermis (67). Human P-cadherin is highly homologous in amino acid sequence with mouse P-cadherin, but it differs in at least one important respect: it is immunohis- 
tochemically not detectable in human placental tissue. P-cadherin is detected in basal layers of stratified epithelia only, and not in simple epithelia (66). P-cadherin may contribute to the maintenance of the proliferative compartment of certain epithelia, whereas E-cadherin presumably plays a major role in the formation and maintenance of epithelial tissues suggested by its broad distribution.

$\mathrm{N}$-cadherin, which is also termed A-CAM or N-CAL-CAM, is detected in many non-epithelial tissues such as neural tissues and muscles (68). N-cadherin will not be discussed in detail in this chapter, that is focussed on CAMs present in epithelial cells potentially involved in the pathogenesis of endometriosis.

\section{Functional aspects of cadherins}

Cadherins play an important role in invasive processes and metastasis of tumor cells $(49,54,62,69,70,71,72,73,74,75)$. E-cadherin was shown to be present in a variety of epithelial tumors, derived from esophagus, stomach, collon, breast, liver and endometrium. However, the staining intensity in cancer tissues is usually lower than in normal tissues, suggesting that there are human cancer cells in which cadherin related intercellular adhesion is impaired. In particular E-cadherin shows stable expression in most epithelial cells and is required to maintain the epithelial phenotype. The expression is not easily influenced as is demonstrated by the fact that even in tissues with chronic inflammation the expression of E-cadherin is maintained. Reduced cadherin expression may be characteristic for malignant transformation, although this loss is not a general property for tumor cells $(48,72)$.

A mechanism for normotopic and stable expression of E-cadherin might exist in normal cells and might be affected by malignant transformation. A malignant tumor cell line derived from mouse ovary tissue, that was highly metastatic, showed unstable expression of $\mathbb{E}$-cadherin (71). Carcinoma cell lines that were non-invasive were shown to express E-cadherin, whereas invasive cell lines had lost E-cadherin (69). E-cadherin-negative cell lines were found to be invasive for collagen gels, whereas E-cadherin-positive lines generally did not enter the extracellular matrix. E-cadherin acts as an invasion suppressor molecule (70). Non-cohesive cells can be transformed into cohesive cells expressing recombinant cadherin, by exogenously introduced cadherin DNA (71). The histologic grade in some types of human cancer is inversely correlated with E-cadherin expression $(62,72,73,74,75,76)$. In endometrial carcinomas E-cadherin expression decreases with loss of differentiation, it is inversely correlated with depth of myometrial invasion and with paraaortic node metastasis (75). Exceptions to the rule are ductal breast carcinomas. Here invasive forms largely retain epi- 
thelial characteristics and express E-cadherin (69). E-cadherin can function as a differentiation marker for a variety of human carcinoma cells. If a temporary or permanent inactivation of cadherins occurs in some cells in tumors, this may enhance their detachment from the main tumor mass.

Expression of E-cadherin is indeed unstable at the transcriptional level in highly metastatic cells (71). Expression of P-cadherin, particularly in gastric carcinoma, has been suggested to be an oncofetal phenomenon, reflecting the marked proliferative potential of these tumors (73). Also expression of P-cadherin is closely related to the differentiation of carcinoma cells.

In summary, cadherins are important determinants of tissue morphology. They play a major role in the maintenance of intercellular junctions in normal epithelial cells in most organs. Cadherin expression is found to be perturbed in human invasive carcinoma. Probably, cadherins are crucial for many other morphogenetic processes which involve selective cell adhesion or detachment.

\section{Integrins}

Integrins are a family of cell membrane glycoproteins consisting of an $\alpha$ and a $\beta$ subunit that mediate cell-cell and cell-matrix adhesion $(77,78,79)$. Integrins appear to be the primary mediators of cell-extracellular matrix interactions. The name integrin was given to underline the presumed role of these proteins in integrating the intracellular cytoskeleton with the extracellular matrix. Currently more than 20 integrin heterodimers are known, which are composed of one of at least fourteen different $\alpha$ and one of eight different $\beta$ chains (80). Some $\alpha$ subunits can combine with more than one $\beta$ subunit. The $\alpha_{v}$ subunit, that combines with different $\beta$ subunits, appears to be particularly versatile (78). The majority of the integrins presently known bind to various extracellular matrix components. These molecules mediate cell-matrix interactions during cell adhesion to basement membranes and other extracellular matrices and during cell migration $(80,81)$. Some integrins are also involved in cell-cell adhesion, i.e. the subunits $\alpha 2$ and $\alpha 3$ (82). The largest number of integrins are member of the $\beta 1$ or very late activation antigen (VLA) subfamily $(77,80)$. The integrins of the $\beta 1$ family, with $\alpha$ chains $\alpha 1$ to $\alpha 6$ serve as receptors for matrixproteins laminin

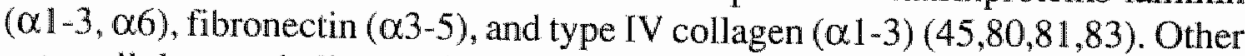
extracellular matrix ligands for integrins are entactin, tenascin, thrombospondin, von Willebrand factor, and vitronectin (78). In some cases (i.e. the fibronectin receptor), specific peptide regions within extracellular matrix proteins have been identified as the integrin-binding sites. This is the tripeptide arginin-glycineaspartic acid (RGD) sequence. The distribution pattern of the integrins in tissues, and how these patterns are affected by disease, is rather unknown, in particular 
with respect to the female genital tract. The cells of most tissues express $\alpha 1 \beta 1$, $\alpha 2 \beta 1, \alpha 3 \beta 1$ and $\alpha 6 \beta 1$, the integrins which are primarly required for adhesion to collagen and laminin. The integrin $\alpha 5 \beta 1$ is expressed to a lesser extent in most tissues, with the exception of large vessel endothelial cells. Leukocytes generally contain integrins of the $\beta 2$ subfamily along with $\alpha 4 \beta 1, \alpha 4 \beta 7, \alpha 5 \beta 1$ and $\alpha 6 \beta 1(79)$.

\section{Functional aspects of integrins}

Functionally, integrins have been found to be involved in thrombosis (platelet aggregation), immune functions (inflammation), tissue repair and cancer. Although careful, comparative information is rather limited, the pattern of integrin expression on transformed, cultured cells appears to be complex and dependent on the cell type. The integrin expression of cultured cells is not similar to that found in situ (84). The relationship of integrin expression and the progression of epithelial tumors such as lung, breast, skin and gastrointestinal tract appears to be complex. Normal cells deposit laminin, fibronectin, collagens and other extracellular matrix components as a protein network around them. Cells can adhere to this matrix through the cell adhesion molecules exposed at the plasma membrane (integrins). In carcinoma cells there is a trend towards expression of fewer types and numbers of integrins than in normal epithelial tissues. In general there is a lower level of expression of some integrin sub-units (in particular the collagen and laminin binding subunits $\alpha 2, \alpha 3$ and $\alpha 6$ ) in the poorly differentiated carcinomas. Tumors that are more invasive and lack intact basement membranes tend not to express basement membrane protein binding integrins (79). Particularly in early stages of tumor growth (release from the tumor mass) a decreased adhesion could be of advantage to tumor cells. In contrast, malignant melanomas have a consistent upregulation of specific integrins during tumor progression. Enhanced expression of integrins on tumor cells after they reach the circulation can promote implantation and metastasis. It remains to be demonstrated if these alterations of integrin expression have a causal relationship in tumor biology.

The fibronectin receptor and the related integrins have intracellular association with actin bundles. The integrin mediated adhesion sites and the zonula adherens share common components such as vinculin. This may imply that the cadherin-mediated cell-cell adhesion and the integrin mediated cell extracellular matrix adhesion have in part a common regulatory mechanism. 


\section{Endometrium and integrins}

Integrins have been detected in human endometrium $(82,83,86,87,88)$. Integrins could be functionally involved in implantation, trophoblast invasion and invasiveness of endometrial carcinoma cells. Integrins of the $\beta 1$ family have been studied in most detail. Glandular epithelium expresses $\alpha 1-\alpha 6 \beta 1$. Surface epithelium also expresses these integrins, with the exception of $\alpha A \beta 1$ (83). Endothelial cells in endometrium are positive for all integrins mentioned above. Endometrial lymphoid cells are positively stained for $\alpha 1 \beta 1, \alpha A \beta 1$ and $\alpha 5 \beta 1$, but negative for $\alpha 2 \beta 1, \alpha 3 \beta 1$ and $\alpha 6 \beta 1$. There is discrepancy in the literature about the expression of some of the integrins such as $\alpha 1 \beta 1, \alpha 2 \beta 1, \alpha 4 \beta 1$. Tabibzadeh (83) could detect $\alpha 4 \beta 1$ only in endometrium from the mid-proliferative and midsecretory phase of the cycle, whereas Lessey et all. (82) could not detect this subunit at all in human endometrium.

Also conflicting reports exist on cycle dependency of integrin expression. Integrin $\alpha 1 \beta 1$ was reported by Tabibzadeh (83) only to be present after the ovulation during the secretory phase of the cycle. The $\alpha 6$ and $\alpha 2$ integrin subunit were found by Bischof and coworkers (85) to be localized both on the surface and the glandular epithelium of the endometrium. These authors reported that the expression of both integrins was increased during the secretory phase of the cycle and became low or indetectable after decidualization (85). In contrast in a study by Lessey and co-workers a uniform expression throughout the cycle was observed for $\alpha 2, \alpha 3$ and $\alpha 6$ (82).

The expression of $\alpha 5$ was weak in endometrial epithelia. Stromal cells showed $\alpha 5$ expression throughout the cycle and increased in decidualized endometria (85). The $\alpha 5$ subunit has been correlated with the appearance of an invasive phenotype on cytotrophoblastic cell surfaces (85). Observations with regard to possible dependency of integrin expression on the menstrual cycle, were mostly done in relative small numbers of samples from endometria obtained from patients that were operated for benign conditions such as myomas $(82,83,85)$. The endometria were dated retrospectively as being from either the proliferative, early secretory or late secretory phase of the cycle. The cycle phase was neither monitored by ultrasound, nor by measurement of the steroids during the respective cycle phase. It remains therefore unclear whether these endometrium samples were obtained from patients with normal ovulatory cycles and whether they were obtained from the defined cycle phase. Furthermore, in the study of Bischof and coworkers (85) some samples from abortion aspirates between 6 and 12 weeks were used.

The differences that were reported could also be attributed to the use of different monoclonal antibodies against integrin subunits. Most authors could not, for example, detect expression of $\alpha 5$ in glandular epithelium, but either 
found it restricted to the stromal component of the endometrium or could not detect it at all $(82,83,85,86)$.

The suggestion has been made that the expression of integrins might be modulated by ovarian hormones (83). The changes in the integrin expression, that have been reported, may be linked to the level of steroids and may be significant in the priming of the endometrium for implantation. The integrins of the $\beta 1$ family were found to be present during the luteal phase of the cycle, except for $\alpha 5 \beta 1$ (86). In contrast to the previously mentioned studies Klentzeris and coworkers (86) dated the cycle phase using daily $\mathrm{LH}$ assays and progesterone measurements. A difference in expression of $\alpha 4 \beta 1$ was found between a group of fertile women and a group of patients suffering from unexplained infertility ( 86$)$. Endometrium from the luteal phase of the cycle from the latter group did not show expression of $\alpha 4 \beta 1$. The observed differences between infertile and fertile women were related to glandular and surface epithelium. It is possible that during the luteal phase, the expression of integrins by the endometrium has a positive effect on uterine receptivity through facilitation of cell-extracellular matrix recognition and subsequent attachment of the blastocyst to the endometrium. The absence of $\alpha 4 \beta 1$ was suggested to result in incomplete embryo-maternal recognition (86).

Special mention deserve the observations made on the vitronectin receptor $\alpha_{v} \beta 1$. The $\alpha_{\mathrm{v}}$ expression was reported to increase during the menstrual cycle, while the $\beta 3$ subunit appeared only from cycle day 20 onwards (82). In women with retarded endometrial progression (luteal deficiency), this integrin was lacking and the suggestion of involvement in implantation was therefore made (82). In yet another study, the observation of abnormal $\beta 3$ integrin expression was frequently made in a group of patients with unexplained infertility (87). In particular a reduced expression during the luteal phase in these patients was noted.

Since several combinations of integrin subunits are possible, the mere localization of one particular integrin subunit cannot lead to a definite conclusion about the type of adhesion receptor that is localized there, let alone about the meaning of this finding with respect to function. The wide distribution of expression of integrin molecules in endometrial tissue emphasizes the important role that they will have to play in cell-extracellular matrix and to a lesser extent cell-cell interactions in human endometrium.

In summary, expression of integrins allows binding of endometrial cells to various ligands (fibronectin, laminin, collagens) and hence adds to the preservation of the architectural integrity of endometrium. The integrin expression by the endometrium seems to be a dynamic process, many details of which still remain to be elucidated. 


\section{Synopsis}

Although endometriosis is a frequently encountered condition in gynecology, already known since 1860 , the pathogenesis of endometriosis is still poorly understood. The implantation theory, that is most widely accepted to explain the pathogenesis, is based on the assumption that retrograde menstruation occurs and hence viable endometrial cells reach the peritoneal cavity (8). These endometrial cells can subsequently implant and grow out to become endometriotic lesions. In this process, adhesion of endometrial cells to the peritoneal lining of the abdominal cavity is of pivotal importance. 


\section{References}

1. Von Rokitansky C. Ueber Uterusdrisen-Neubildung in Uterus- und Ovarial- Sarcomen. Ztschr KK Gesellsch der Aerzte zu Wien 1860; 37: 577-581

2. Cullen TS. Adeno-myoma uteri diffusum benignum. Johns Hopkins Hosp Bull 1896; 6: $133-137$.

3. Cullen TS. Adeno-myoma of the round ligament. Johns Hopkins Hosp Bull 1896; 7: $112-114$.

4. Ridley $\mathbf{J H}$. The histogenesis of endometriosis. A rewiew of facts and fancies. Obstet Gynecol Survey 1968;23:1-23.

5. Lauchlan SC. The secondary Müllerian system. Obstet Gynecol Survey $1972 ; 27$ : $133-146$.

6. Levander G, Normann P. The pathogenesis of endometriosis. An experimental studly. Acta Obstet Gynecol Scand 1955; 34:366-398.

7. Merrill JA. Endometrial induction of endometriosis across Millipore filters. Am J Obstet Gynecol 1966; 94: 780-790.

8. Sampson JA. Peritoneal endometriosis due to the menstrual dissemination of endometrial tissue into the peritoneal cavity. Am J Obstet Gynecol 1927:14:422 469 .

9. Sampson JA. The development of the implantation theory for the origin of peritoneal endometriosis. Am J Obstet Gynecol 1940; 40: 549-557.

10. Meyer R. Zur Frage der Umieren-genese von Adenomyomen. Zentral BI Gynäkol 1923; 15: 577-587.

1. Russell WW. Aberrant portions of the Müllerian duct found in an ovary. Ovarian cysts of Müllerian origin. Bull John Hopkins Hosp 1899; 10: 8-10.

12. Lauche A. Die extragenitalen heterotopen Epithelwucherungen vom Bau der Uterusschleimhaut. (Fibroadenomatosis seroepithellialis). Virch Arch 1923; 243: 298-373.

13. Iwanoff NS. Drusiges cysthaltiges Uterusfibromyom compliziert durch Sarcom und Carcinom (Adenofibromyoma cysticum arcomatodes carcinomatosum). Monatschr Geburtsh Gynäkol 1898; 7: 295-300.

14. Meyer R. Zur Frage der heterotopen Epithelwucherung, insbesondere des Peritonealepithels und in die Ovarien. Virch Arch Path Anat Phys 1924; 250: 595-610.

15. Meyer R. Ueber den stand der Frage der Adenomyositis und Adenomyome in algemeinen und insbesondere uber Adenomyositis serosoepithelialis und Adenomyometritis sarcomatosa. Zentralbl Gynäkol 1919; 43: 745-750.

16. Novak E. Pelvic endometriosis. Spontaneous rupture of endometrial cysts, with a report of three cases. Am J Obstet Gynecol 1931; 22: 826-837.

17. Suginami H. A reappraisal of the coelomic metaplasia theory by reviewing endometriosis occurring in unusual sites and instances. Am J Obstet Gynecol 1991; 165: 214-218.

18. Novak $\mathbf{E}$. The significance of uterine mucosa in the fallopian tube with a discussion of the origin of aberrant endonetrium. Am J Obstet Gynecol 1926; 12:484-525.

19. Halban J. Hysteroadenosis metastatica. Zentralbl Gynäkol 1925; 7: 387-391.

20. Halban J. Hysteroadenosis metastatica. Wien Klin Wschr 1924; 37: 1205-1206.

21. Haney AF. The pathogenesis and aetiology of endometriosis. In Thomas EJ, Rock JA, eds. Modern approaches to endometriosis. Dordrecht, Boston, London: Kluwer Academic Publisher, 1991: 3-19. 
22. Keettel C, Stein RJ. The viability of the cast off menstnual endometrium. Am J Obstet Gynecol 1951; 61:440-442.

23. Cron RS, Gey $\mathbf{G}$. The viability of the cast-off menstrual endometrium. Am J Obstet Gynecol 1927:13:645-647.

24. Geist SH. The viability of fragments of menstrual endometrium. Am I Obstet Gynecol $1933 ; 25: 751$.

25. Ridley $\mathbf{J H}$, Edwards $\mathbf{I K}$. Experimental endometriosis in the human. Am J Obstet Gynecol 1958; 76:783-790.

26. Van der Horst CJ, Gilman J. The menstruation cycle in elephantulus. South Afr J Med Sci 1941: $6: 27-47$.

27. Rasweiler WJ. Early embryonic development and implantation in bats. I Reprod Fertil 1979; $56: 403-416$.

28. Finn CA. Why do women and some other primates menstruate? Perspect Biol Med 1987; 30: 566-574.

29. Watkins $\mathbf{R E}$. Uterine retrodisplacements, retrograde menstruation and endometriosis. West J Surg Obstet Gynecol 1938; 46: 480-494.

30. Blumenkrantz MJ, Gallagher N, Bashore RA, Tenckhoff H. Retrograde menstruation in women undergoing chronic peritoneal dialysis. Obstet Gynecol 1981; 57 : 667670.

31. Halme J, Hammond MG, Hulka JF, Raj SG, Talbert LM. Retrograde menstruation in healthy women and in patients with endometriosis. Obstet Gynecol 1984; 64: 151-154.

32. Beyth Y, Yaffe H, Levij IS, Sadovsky E.. Retrograde seeding of endometrium: a sequela of tubal flushing. Fertil Steril 1975; 26: 1094-1097.

33. Bartosik D, Jacobs SL, Kelly LJ. Endometrial tissue in peritoneal fluid. Fertil Steril 1986; 46: 796-800.

34. Kullenthran A, Jeyalakshmi N. Dissemination of endometrial cells at laparoscopy and chromotubation. A preliminary report. Int J Fertil 1989; 34: 256-258.

35. Kruitwagen RFPM, Poels LG, Willemsen WNP, de Ronde IJY, Jap PHK, Rolland R. Endometriat epithelial cells in peritoneal fluid during the early follicular phase. Fertil Steril 1991; 55: 297-303.

36. Badawy SZA, Cuenca V, Marshall L, Munchback R, Rinas AC, Coble DA. Cellular components in peritoneal fluid in infertile patients with and without endometriosis. Fertil Steril 1984; 42: 704-707.

37. Koninckx $\mathbf{P R}$, Ide $\mathbf{P}$, Vandenbroucke W, Brosens IA. New Aspects of the pathophysiology of endometriosis and associated infertility. J Reprod Med 1980; 24: 257-260.

38. Jenkins S, Olive DL, Haney AF. Endometriosis: pathogenetic implications of the anatomic distribution. Obstet Gynecol 1986; 67: 335-338.

39. Oosterlynck DJ, Meuleman C, Waer M, Vandeputte M, Koninckx PR. The natural killer activity of peritoneal fluid lymphocytes is decreased in women with endometriosis. Fertil Steril 1992; 58: 290-295.

40. Reti LL, Byrne GD, Davoren RAM. The acute clinical features of retrograde menstruation. Aust N Z J Obstet Gynaecol 1983; 23; $51-52$.

41. Willemsen WNP, Mungyer G, Smets H, Rolland R, Vemer H, Jap P. Behavior of cultured glandular cells obtained by flushing of the uterine cavity. Fertil Steril $1985 ; 44$ : 92-95.

42. Hingst JW. Pathologisch-anatomisch en experimenteel onderzoek over den bouw en de ontwikkeling wan ectopisch uterus-slijmvliesweefsel (endometriose). Thesis University of Utrecht, 1926. 
43. Takeichi M. Cadherins: A molecular family important in selective cell-cell adhesion. Annu Rev Biochem 1990; 59: 237-252.

44. Geiger B, Ginsberg D, Salomon D, Volberg T. The molecular basis for the assembly and modulation of adherens-type junctions. Cell Differ Dew 1990; 32: 343-354.

45. Katz AM, Rosenthal D, Sauder DM. Cell adhesion molecules. Structure, function and implication in a variety of cutaneous and other pathologic conditions. Int I Dermatol 1991; 30: 153-160.

46. Ozawa M, Engel J, Kemler $\mathbf{R}$. Single amino acid substitutions in one $\mathrm{Ca}^{2+}$ binding site of uvomorulin abolish the adhesive function. Cell 1990; 63: 1033-1038.

47. Kemler R, Ozawa M, Ringwald M. Calcium-dependent cell adhesion molecules. Curr Opin Cell Biol 1989; 1: 892-897.

48. Takeichi M. The cadherins: cell-cell adhesion molecules controlling animal morphogenesis. Development 1988; 102: 639-655.

49. Takeichi M. Cadherin cell adhesion receptors as a morphogenetic regulator. Science $1991 ; 251: 1451-1455$.

50. Eidelman S, Damsky CH, Wheelock MJ, Damjanov I. Expression of the cell-cell adhesion glycoprotein cell-CAM 120/80 in normal human tissues and tumors. Am J Pathol 1989; 135:101-110.

51. Nose A, Nagafuchi A, Takeichi $\mathbf{M}$. Expressed recombinant cadherins mediate cell sorting in model systems. Cell 1988; 54: 993-1001.

52. Kemler R, Babinet $\mathbf{C}$, Eüsen $\mathbf{H}, \mathbf{J a c o b} \mathbf{F}$. Surface antigen and early differentiation. Proc Natl Acad Sci USA 1977; 74: 4449-4452.

53. Vestweber $\mathbf{D}$, Kemler $\mathbf{R}$. Identification of a putative cell adhesion domain of uvomorulin. EMBO J 1985; 4: 3393-3398.

54. Biehrens J, Mareel MM, Van Roy FM, Birchmeier W. Dissecting tumor cell invasion: epithelial cells acquire invasive properties after the loss of uvomorulin-mediated cell-cell adhesion. J Cell Bioll 1989; 108: 2435-2447.

55. Hatta K, Okada TS, Takeichi M. A monoclonal antibody disrupting calcium-dependent cell-cell adhesion of brain tissues:possible role of its target antigen in animal pattern formation. Proc Natl Acad Sci USA 1985; 82: 2789-2793.

56. Nose A, Takeichi M. A novel cadherin cell adhesion molecule: its expression patterns associated with implantation and organogenesis of mouse embryos. J Cell Biol 1986; 103: 2649-2658.

57. Suzuki $\mathbf{S}$, Sano $\mathbf{K}$, Tanihara $\mathbf{H}$. Diversity of the cadherin family: evidence for eight new cadherins in nervous tissue. Cell Regulat $1991 ; 2: 261-270$.

58. Nagafuchi A, Takeichi M. Cell binding function of E-cadherin is regulated by the cytoplasmic domain. EMBO J 1988; 7: 3679-3684.

59. Ringwald M, Schuh R, Vestweber D, Eistetter H, Lottspeich F, Engel J, Dölz R, Jähnig F, Epplen J, Mayer S Müller C, Kemler R. The structure of cell adhesion molecule uvomorulin. Insight into the molecular mechanism of $\mathrm{Ca}^{2+}$-dependent cell adhesion. EMBO J 1987; 6: 3647-3653.

60. Friedllander DR, Mège R-M, Cunningham BA, Edelman GM. Cell sorting-out is modulated by both the specificity and amount of different cell adhesion molecules (CAMs) expressed on cell surfaces. Proc Natl Acad Sci USA 1989; 86:7043-7047.

61. Jaffe SH, Friedlander DR, Matsuzaki F, Crossin KL, Cunningham BA, Edelman GM. Differential effects of the cytoplasmic domains of cell adhesion molecules on cell aggregation and sorting out. Proc Natl Acad Sci USA 1990; 87: 3589-3593. 
62. Inoue M, Ogawa $\mathbf{H}$, Miyata M, Shiozaki H, Tanizawa O. Expression of E-cadherin in normal, benign, and malignant tissues of female gental organs. Am J Chin Pathol 1992: $98: 76-80$.

63. Damjanow I, Damjanov A., Damsky CH. Developmentally regulated expression of the cell-cell adhesion glycoprotein cell-CAM $120 / 80$ in peri-implantation mouse embryos and extraembryonic membranes. Dewl Biol 1986; 116:194-202.

64. Edelman GM. Morphoregulatory molecules. Biochem 1988; 27: 3533-3543.

65. Shimoyama $\mathbf{Y}$, Mirohashi S, Hirano S, Noguchi M, Shimosato $Y$, Takeichi M, Abe O. Cadherin cell-adhesion molecules in human epithelial tissues and carcinomas. Cancer Res 1991: 51:2185-2191.

66. Shimoyama Y, Yoshida T, Terada M, Shimosato Y, Abe O, Hirohashii S. Molecular cloning of a human $\mathrm{Ca}^{24}$-dependent cell-cell adhesion molecule homologues to mouse placental cadherin: its low expression in human placental tissues. J Cell Biol 1989; 109: 1787-1794.

67. Kadokawa $\mathbf{Y}$, Fuketa I, Nose A, Takeichi M, Nakatsuji N. Expression pattern of E-cadherin and P-cadherin in mouse embryos and uteri during the periimplantation period Dev Growth Differ 1989; 31:23-30.

68. Hatta K, Takagi S, Fujisawa H, Takeichi M. Spatial and temporal expression pattem of $\mathrm{N}$-cadherin cell adhesion molecules correlated with morphogenetic processes of chicken embryos. Devi Biol 1987; 120: 2115-227.

69. Frixen UH, Behrens J, Sachs M, Eberle G, Voss B, Warda A, Löchner D, Birchmeier W. E-Cadherin mediated cell-cell adhesion prevents invasiveness of human carcinoma cells. J Cell Biol 1991; 113: 173-185.

70. Vlemminckx K, Vakaet $\mathbf{L}$, Mareel M, Fiers W, van Roy F. Genetic manipulation of E-Cadherin expression by epithelial tumor cells reveals an invasion suppressor role. Cell 199:;66:107-119.

71. Hashimoto $\mathbf{M}$, Niwa $\mathbf{O}$, Nitta $\mathbf{Y}$, Takeichi $\mathbf{M}$, Yokoro $\mathbf{K}$. Unstable expression of E-Cadherin adhesion molecules in metastatic ovarian tumor cells. Jpn $J$ Cancer Res 1989; 80:459-463.

72. Shiozaki H, Tahara H, Oka H, Myata M, Kobayashi K, Tamura S, Iihara $K$, Doki Y, Hirano S, Takeichi M, Mori T. Expression of immunoreactive E-cadherin adhesion molecules in human cancers. Am J Pathol 1991; 139: 17-23.

73. Shimoyama $\mathbf{Y}$. Hirohashi $\mathbf{S}$. Expression of $\mathbf{E}$-and P-cadherin in gastric carcinomas. Cancer Res 1991; $51: 2185-2192$.

74. Shimoyama $\mathrm{X}$, Hirohashi $S$. Cadherin intercellular adhesion molecule in hepatocellular carcinomas: loss of E-cadherin expression in an undifferentiated carcinoma. Cancer Let 1991; $57: 131-135$.

75. Sakuragi N, Nishiya M, Ikeda K, Ohkouch T, Furth EE, Hareyama H, Satoh C, Fujimoto $\mathrm{S}$. Decreased E-cadherin expression in endometrial carcinoma is associated with tumor dedifferentiation and deep myometrial invasion. Gynecol Oncol 1994; 53: 183-189.

76. Umbas R, Schalken JA, Aalders TW, Carter BS, Karthaus HF, Schaffsma HE, De Bruyne FM, Isaacs WB. Expression of the cellular adhesion molecule E-cadherin is reduced or absent in high-grade prostate cancer. Cancer Res 11992; 52: 5104-5109.

77. Albelda SM, Buck CA. Integrins and other cell adhesion molecules. FASEB J 1990; 4: 2868-2880.

78. Ruoslahti E. Integrins. J Clin Invest 1991; 87: $1-5$. 
79. Albelda SM. Biology of disease. Role of integrins and other cell adhesion molecules in tumor progression and metastasis. Lab Invest 1993;68:4-17.

80. Hynes RO. Integrins: Versatility, modulation, and signaling in cell adhesion. Cell 1992; 69:11-25.

81. Hynes RO, Lander AD. Contact and adhesive specificities in the associations, migrations and targeting of cells and axons. Cell 1992; 68: 303-322.

82. Lessey BA, Damjanovich L, Coutifaris C, Castelbaum A, Albelda SM, Buck CA. Integrin adhesion molecules in the human endometrium. Correlation with the normal and abnomal menstrual cycle. J Clin Invest 1992; 90:188-195.

83. Tabibzadeh S. Patterns of expression of integrin molecules in human endometrium throughout the menstrual cycle. Hum Reprod 1992; 7: 876-882.

84. Albelda SM. Endothelial and epithelial cell adhesion molecules. Am J Respir Cell Mol Biol 1991; 4: 195-203.

85. Bischof $\mathbf{P}$, Redard M, Gindre $\mathbf{P}$, Vassilakos $\mathbf{P}$, Campana A. Localization of alpha 2 , alpha 5 and alpha 6 integrin subunits in human endometrium, decidua and trophoblast. Eur J Obstet Gynaecol Reprod Biol 1993; 51: 217-226.

86. Klentzeris LD, Bulmer JN, Trejdosiewicz LK, Morrison L, Cooke ID. Beta-1 integrin cell adhesion molecules in the endometrium of fertile and infertile women. Hum Reprod 1993: 8: 1223-1230.

87. Lessey BA, Castelbaum AJ, Sawin SW, Sun J. Integrins as markers of uterine receptivity in women with primary unexplained infertility. Fertil Steril 1995; 63: 535 542.

88. Lessey BA. Integrins and assisted reproduction. Assisted Reproduction Reviews 1993; 3: $56-63$. 

Chapter 2

Aims of the study 
In the pathogenesis of endometriosis, according to the implantation theory, the adhesion to the peritoneum of endometrial cells, which are retrogradely shed into the abdominal cavity through the fallopian tubes, is essential. The conditions that have to be met for this theory are threefold, firstly, retrograde menstruation has to occur, secondly, retrograde menstruation should contain viable endometrial cells, and, thirdly, adhesion to the peritoneum has to occur with subsequent implantation and proliferation. We hypothesize that specific cell adhesion molecules, i.e. cadherins and integrins, are functionally involved in this adhesion.

At present, it is not known which endometrial cells, i.e. epithelial and/or stromal cells, are involved in this adhesion process. The same applies to the peritoneum with respect to the epithelial lining and the extracellular matrix (Figure). In theory, either the glandular epithelial cells or stromal cells can come into contact with the mesothelium, the epithelium which covers the peritoneum. Probably both cell types may even interact in order to effectuate this first contact. Another possibility could be direct contact of endometrial cells with the extracellular matrix, which would require disruption of (or damage to) the peritoneall lining. Specific adhesion molecules, i.e. cadherins and integrins, could be functionally involved in this adhesion. In this study we wish to focus on how this process of first contact and adhesion can occur.

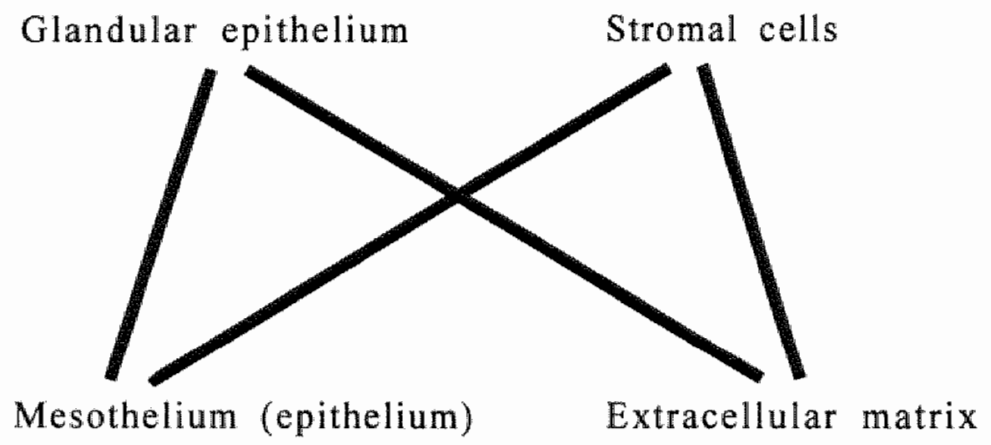

The first goal of the present study is to better characterize retrograde menstruation. To this end, the presence of endometrial cells in peritoneal fluid during the early follicular phase of the cycle will be studied. The results of this study will be reported in chapter 3 .

If the assumption is correct that cell adhesion molecules account for adhesion of endometrial cells to peritoneum, which may lead to endometriosis, they should be expressed on these cells and on cells that are potentially involved in the pathogenesis of endometriosis. Cadherins are the most important cell adhesion molecules controlling cell-cell adhesion and integrins are the most important cell 
adhesion molecules involved in cell-extracellular matrix interactions. It was decided to focus on these two cell adhesion molecules.

The second goal is to assess which sub-classes of cadherins and integrins are expressed in the endometrium (glandular tissue and stroma), antegrade and retrograde menstrual effluent, peritoneum and endometriosis.

The following questions will be addressed:

a. Which adhesion molecules are expressed on the different cell types?

b. Is expression of cell adhesion molecules related to the phase of the menstrual cycle?

The study will be limited to E-and P-cadherins and the integrins of the $\beta 1$ family. The results of these studies will be discussed in chapter 4 and 5 with respect to the first question. The changes in expression of cell adhesion molecules in endometrium throughout the menstrual cycle will be addressed in chapter 6 .

The third goal is to study functional aspects of adhesion. Therefore we will develop a model to assess adhesion of endometrial tissue and cells to peritoneum in vitro. The following questions will be addressed in this model:

a. Does adhesion occur between tissue of endometrial and of peritoneal origin in vitro?

b. If so, what is the mechanism of cell adhesion in the initial phases of attachment and which adhesion molecules are functionally involved?

In chapter 7 we will introduce an in vitro model for the study of endometrial cell-extracellular matrix interactions. Amniotic membranes, after stripping of their epithelial lining, will serve as an extracellular matrix. Also the expression of cell adhesion molecules will be evaluated.

In chapter 8 , adhesion in vitro between endometrial cells and extracellular matrix, covered by an intact epithelial lining serving as a model for peritoneum, will be studied. 



\section{Chapter 3}

\section{Epithelial cells in peritoneal fluid: of endometrial origin?}

P.J.Q. van der Linden, G.A.J. Dunselman, A.F.P.M. de Goeij, E.P.M. van der Linden, J.L.H. Evers and F.C.S. Ramaekers

American Journal of Obstetrics and Gynecology 1995; 173: 566-570 (reprinted with permission) 


\section{Abstract}

Objective: Our purpose was to examine the immunohistochemical properties of epithelial cells in peritoneal fluid and to compare the staining characteristics with cells of endometrium, menstrual effluent, peritoneum, and endometriotic lesions.

Study design: Samples of menstrual effluent, endometrium, peritoneal fluid, and biopsy specimens of endometriotic lesions and peritoneum from 16 patients were examined. Monoclonal antibodies against vimentin, cytokeratin 18 and 19 , and the monoclonal antibody BW495/36, staining an epithelial marker present in endometrium and absent in peritoneal epithelium, were used.

Results: All but one sample of menstrual effluent and peritoneal fluid cells stained positively with antibodies against vimentin, cytokeratin 18 and 19 . BW495/36 stained 14 of 16 menstrual effluent samples and nine of 16 peritoneal fluid cell samples. Endometriotic specimens staining with all markers. No major differences in staining properties were observed in menstrual effluent, endometrium and peritoneal fluid cells between patients with or without endometriosis.

Conclusion: These results support the contention of transport of menstrual detritus to the peritoneal cavity in women with patent fallopian tubes.

\section{Introduction}

Retrograde menstruation and peritoneal adhesion of endometrial tissue are essential elements in the pathogenesis of endometriosis, according to Sampson's classical implantation theory (1-3). Menstrual effluent is composed of extracellular fluid, blood elements, and endometrial cells. The presence of blood in peritoneal fluid during the menstrual phase of the cycle has been observed $(4,5)$. Several groups of investigators have reported the presence of endometrial tissue in peritoneal fluid of women with patent tubes, irrespective of the presence of endometriosis (6-11). However, the number of women with endometrial tissue in the peritoneal fluid was smaller $(0-59 \%)$ than the reported incidence of bloody peritoneal fluid in women with patent tubes (upto 90\%). Because of the methods used for detection (i.e. Papanicolaou staining), only clumps of cells, and not single cells, could be detected and recognized as originating from endometrial tissue. Recently, Kruitwagen et al. (9) have demonstrated the presence of viable endometrial cells in peritoneal fluid. These authors succeeded in culturing these cells in vitro, and their data strongly support an endometrial origin of epithelial cells in peritoneal fluid.

The aim of the current study was to detect the presence of single endometrial cells or tissue fragments in peritoneal fluid in the early follicular phase of the 
menstrual cycle by use of immunohistochemistry with antibodies to epithelial markers. Also, we wanted to compare the immunohistochemical staining properties of the endometrial tissue fragments in peritoneal fluid with those of cells present in endometrium, menstrual effluent, peritoneum, and endometriotic lesions.

\section{Materials and methods}

A diagnostic laparoscopy was performed in 16 women as part of their subfertility work-up. All women had a regular ovulatory cycle, as clemonstrated by ultrasonography and an adequate rise in serum progesterone in the luteal phase of the cycle. Laparoscopy was performed in the early follicular phase (day 2 to day 5). At the start of the laparoscopy menstrual effluent was collected from the vagina with a syringe. A sample of endometrium was obtained by using a Probet endometrial sampling device (Gynetics, Oisterwijk, The Netherlands). The laparoscopy was performed by a double puncture technique. Peritoneal fluid was collected immediately after introduction of the second trocar. When endometriosis was identified, it was staged according to the revised American Fertility Society classification (12). Subsequently, a representative biopsy specimen of an endometriotic lesion was obtained using a biopsy forceps, and in two patients an additional biopsy specimen was obtained from unaffected peritoneum. When no endometriosis was detected, a peritoneal biopsy specimen was obtained from the pouch of Douglas. The samples of menstrual effluent and endometrium were frozen in isopentane immersed in dry ice. The tissue biopsy specimens were embedded in Tissue Tek ornithine carbamyl transferase compound (Miles Scientific, Elkhart, Ind.) and also frozen immediately. The peritoneal fluid samples were centrifuged for 5 minutes. After removal of the supernatant, the remaining pellet was frozen in isopentane in dry ice. All samples were stored at $-70^{\circ} \mathrm{C}$ until analysis.

\section{Immunohistochemical staining procedures}

Cryostat sections $4 \mu \mathrm{m}$ thick were prepared and mounted on slides. The sections were air-dried and fixed with methanol at $-20^{\circ} \mathrm{C}$ for 1 minute, followed by an acetone dip at $-20^{\circ} \mathrm{C}$. Slides were washed three times for 5 minutes in phosphate buffered saline solution, and immersed in $0.3 \%$ hydrogen peroxide to block endogenous peroxidase activity. The sections were washed again three times for 5 minutes in phosphate buffered saline solution. A series of mouse monoclonal antibodies were used including RV 202 for vimentin, RCK 106 for cytokeratin 18, RCK 108 for cytokeratin 19, respectively (13). Also the monoclonal antibody BW495/36 was applied, recognizing an epithelial marker present in endometrial epithelium but not in mesothelium (14). Incubation with primary antibodies 
against vimentin and the cytokeratins was done in appropriate dilutions for 60 minutes at room temperature. After being washed three times for 10 minutes in phosphate buffered saline solution, the sections were incubated for 60 minutes with rabbit anti-mouse immunoglobulin $\mathrm{G}$ conjugated with horseradish peroxidase (Dako A/S, Glostrup, Denmark). For staining with BW495/36 a streptavidin-biotin complex method was used. In brief, after incubation with the primary antibody the slides were washed three times for 10 minutes and then incubated for 30 minutes with biotin-labeled sheep anti-mouse immunoglobulin G (Amersham Nederland B.V., Den Bosch, The Netherlands). After being washed in phosphate buffered saline solution, the sections were incubated with a streptavidin-biotin-peroxidase complex (Dako A/S, Glostrup, Denmark) for 30 minutes. Antibody binding was visualized using 3'-3-diaminobenzidine and hydrogen peroxide. The slides were counterstained with hematoxylin, and stained slides were dehydrated through an alcohol series, cleared in xylene and mounted in Entellan for light microscopy. Negative controls included the procedure with the primary antibody left out, with phosphate buffered saline solution instead. Positive controls consisted of known positive samples of colon and endometrium.

\section{Results}

Endometriosis was identified visually in eight patients, confirmed histologically in all of them, and classified as stage I according to the revised AFS classification in eight of eight patients. All patients had patent tubes. In all peritoneal fluid samples a red color was noted and red blood cells, and epithelial cells were identified at light microscopy. Occasionally endometrial tissue was recognized as clumps of gland-like structures but in most cases as single cells. No difference in the presence of endometrial tissue was observed in patients with or without endometriosis. Also, no major differences in the reactivity patterns of the monoclonal antibodies in celis of menstrual effluent, endometrium, or peritoneal fluid were found between patients with or without endometriosis. Table 1 summarizes the immunohistochemical staining obtained with the various monoclonal antibodies in menstrual effluent, endometrium, peritoneal fluid cells, endometriotic lesions, and peritoneum. Figure 1 illustrates the staining patterns of the various monoclonal antibodies used. Ten peritoneal biopsy specimens were tested, eight from patients without endometriosis and two from patients who also had biopsy of endometriotic lesions at a different site in the pelvis.

Antibodies to vimentin, cytokeratin 18 , and cytokeratin 19 showed positive staining of all the epithelial cells of the menstrual effluent samples but one. In the negative sample no nucleus-containing cells could be recognized. BW495/36 stained the epithelial cells in 14 of 16 menstrual effluent samples. 


\section{Table 1}

Immunohistochemical reactivity patterns of various monoclonal antibodies with epithelial cells of menstrual effluent, endometrium, peritoneal thuid, endometriotic lesions and peritoneum in 16 patients during the early follicular phase of the menstrual cycle.

\begin{tabular}{|c|c|c|c|c|c|}
\hline \multirow[b]{2}{*}{ tissue } & \multirow[b]{2}{*}{ endometriosis } & \multicolumn{4}{|c|}{ monoclonal antibody/antigen } \\
\hline & & $\begin{array}{l}\text { RV } 202 \\
\text { vimentin }\end{array}$ & $\begin{array}{l}\text { RCK } 106 \\
\text { cytokeratin } \\
18\end{array}$ & $\begin{array}{l}\text { RCK } 108 \\
\text { cytokeratin } \\
19\end{array}$ & $\begin{array}{l}\text { BW } 495 / 36 \\
\text { epithelial } \\
\text { marker }\end{array}$ \\
\hline menstrual & + & $8 / 8$ & $8 / 8$ & $8 / 8$ & $8 / 8$ \\
\hline effluent & - & $7 / 8$ & $7 / 8$ & $7 / 8$ & $6 / 8$ \\
\hline \multirow[t]{2}{*}{ endometrium } & + & $8 / 8$ & $8 / 8$ & $8 / 8$ & $8 / 8$ \\
\hline & - & $8 / 8$ & $8 / 8$ & $8 / 8$ & $7 / 8$ \\
\hline peritoneal & + & $6 / 8$ & $8 / 8$ & $8 / 8$ & $5 / 8$ \\
\hline fluid & - & $8 / 8$ & $7 / 8$ & $7 / 8$ & $4 / 8$ \\
\hline \multirow[t]{2}{*}{ peritoneum } & + & $2 / 2$ & $1 / 2$ & $1 / 2$ & $0 / 2$ \\
\hline & - & $8 / 8$ & $8 / 8$ & $8 / 8$ & $0 / 8$ \\
\hline $\begin{array}{l}\text { endometriotic } \\
\text { lesion }\end{array}$ & + & $8 / 8$ & $8 / 8$ & $8 / 8$ & $7 / 8$ \\
\hline
\end{tabular}

Number of cases with positive epithelial cells over number of cases tested.

Endometriosis was found in 8 patients.

All endometrial tissue samples except one were positive for vimentin and for the cytokeratins. BW495/36 did not show positive staining in one endometrium sample, although endometrial glands and stroma could be recognized at light microscopy and the other epithelial markers stained positively.

In peritoneal fluid the epithelial elements were detected by positive staining for cytokeratin 18 and cytokeratin 19 in all samples but one. This one did not contain sufficient epithelial cellular material to allow adequate staining. In one case positive staining for the cytokeratins, but not for vimentin was found. In 

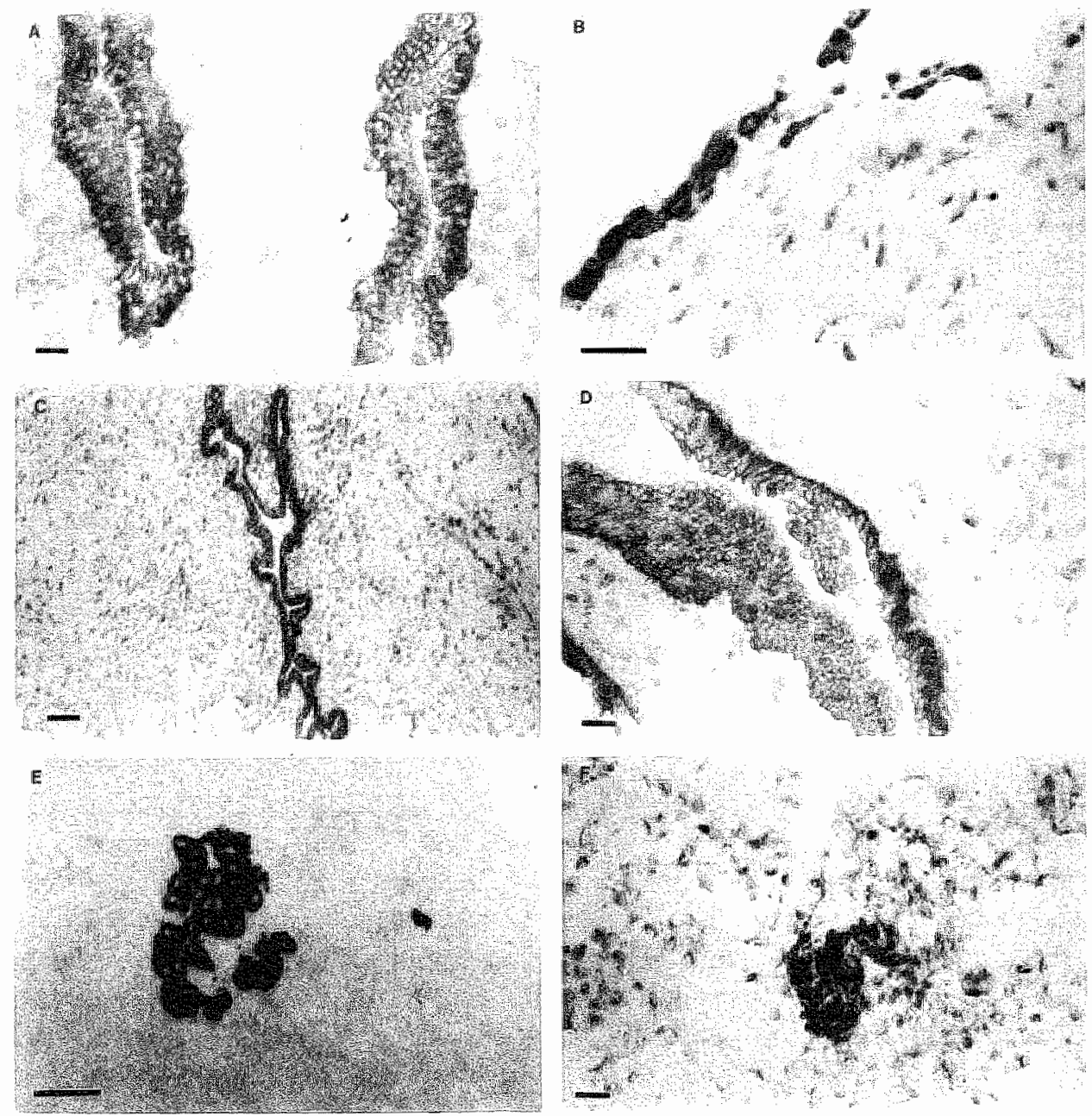

\section{Figure 1}

Staining patterns of various samples after incubation with monoclonal antibodies.

A. endometrium stained with BW495/36, B. peritoneum stained for cytokeratin 18 with RCK 106, C. endometriosis stained for cytokeratia 19 with RCK 108, D. endometriosis stained with BW495/36, E. epithelial cells in peritoneal fluid stained for cytokeratin 18 with RCK 106, F. epithelial cells in peritoneal fluid stained with BW495/36.

Bar indicates 204 . Original magnification: $\times 100$. 
nine of 16 peritoneal fluid samples positive staining was found with BW495/36. All endometriosis samples except one stained for all epithelial markers. In this particular lesion there was positive reactivity for antibodies against vimentin, cytokeratin 18, and cytokeratin 19, but not for BW495/36. Also, the endometrial tissue sample of this patient failed to show positive reactivity with BW495/36.

All the peritoneum samples but one showed positive staining for vimentin, cytokeratin 18 , and cytokeratin 19 in the mesothelial cell layer. In one sample no reactivity for cytokeratin 19 could be found. No reactivity with any of the peritoneum samples was found for the monoclonal antibody BW495/36.

\section{Comment}

Retrograde transport of endometrial tissue and subsequent appearance in peritoneal fluid is considered to play a pivotal role in the pathogenesis of endometriosis (1-3). Retrograde menstruation can be demonstrated by showing in peritoneal fluid the presence of blood, endometrial tissue fragments, by their morphological characteristics, or epithelial components, which express immunohistochemical characteristics similar to endometrium. In the current study during the early follicular phase of the menstrual cycle each peritoneal fluid sample was colored red and contained red blood cells irrespective of the presence of endometriosis. Sampson (1) reported the occurrence of blood dripping from one or both fallopian tubes when a laparotomy was performed during menstruation. Halme et al. (5) found a red color of the peritoneall fluid in $90 \%$ of women with patent tubes, suggesting the presence of blood. Only visual documentation of the color of the peritoneal fluid samples was carried out. It has to be emphasized that these observations merely suggest that peritoneal fluid samples contain blood during menses in women with patent tubes. Reti et al. (15) concluded that the demonstration of blood-stained fluid in the pouch of Douglas at laparoscopy was inadequate for the demonstration of retrograde menstruation, because in their study only a weak correlation was found between blood staining of peritoneal fluid and the presence of endometrial cells. Only the presence of small clusters of cells visually resembling endometrial glands and stroma in the smear made from peritoneal fluid and stained according to Papanicolaou was recognized by these authors as evidence for their endometrial origin.

Demonstration of the presence of endometrial cells in peritoneal fluid is an objective way to assess retrograde menstruation. Various investigators have reported the presence of endometrium-like tissue in the peritoneal fluid of women with patent tubes, irrespective of the presence of endometriosis $(6,7,8,16,17)$. The proportion of women with endometrial tissue detected in peritoneal fluid varied considerably between the studies performed, because of the phase of the cycle studied, the method used for detecting the endometrial 
tissue, and prior flushing of the tubes. With Papanicolaou staining, which was most often used, only clusters of cells will be identified and not individual cells, because this staining cannot differentiate single endometrial cells from mesothelial cells. This methodological problem probably accounts for the difference in incidence between bloody peritoneal fluid and the detection of endometrial tissue in peritoneal fluid from women with patent tubes. In the current immunohistochemical study we studied the peritoneal fluid cell population itself in order to determine the incidence of the presence of endometrial cells in peritoneal fluid of women with patent tubes. Our study demonstrates the presence of epithelial tissue fragments in peritoneal fluid in the early follicular phase of the cycle of all women with patent tubes. No flushing of the fallopian tubes was performed prior to collection of the samples. We did not find a difference in the presence of epithelial components in peritoneal fluid samples from patients with and without endometriosis. Our findings suggest that transport of menstrual detritus with cellular components and tissue fragments to the peritoneal cavity is a physiological phenomenon.

Fifteen of 16 peritoneal fluid samples contained cells that stained positively with monoclonal antibodies against cytokeratins, underlining their epithelial origin. Only nine of these 16 stained positively with BW495/36. This difference may be related to a loss of the epitope for BW495/36 on these cells. It is tempting to suggest that endometrial tissue, after reaching the abdominal cavity, is modulated by the active peritoneal fluid components, leucocytes, macrophages and proteolytic enzymes, resulting in single epithelial endometrial cells rather than endometrial tissue fragments. This is supported by the fact that we only occasionally found endometrial tissue as gland-like structures in the peritoneal fluid. Consequently, staining for epithelial markers that react with epitopes on the plasma membrane rather than intracellular filaments will be less intense. When these single cells attach to the peritoneal lining or to the underlying basement membrane and develop into endometriotic implants, the reactivity of BW495/36 occurs again. Kruitwagen et al. (14) have found viable endometrial cells in $79 \%$ of women with patent tubes when culturing the cellular components of peritoneal fluid in vitro. A second explanation for this phenomenon might well be a technical artefact. The intermediate filament proteins such as cytokeratins and vimentin are abundant constituents of the intracellular cytoskeleton. When an antibody is applied directed against one of these components, a strong staining intensity throughout the cell can be expected. The reactivity of BW495/36 is much more limited to the cellular boundaries, and its epitope has not yet been identified. The use of sections rather than smears may influence the detectability of this antigen. The antibody has been shown, however, to stain endometrial epithelium and not mesothelium and is therefore a strong discriminating agent. Monoclonal antibodies against cytokeratins can not be used to discriminate between epithelial cells from endometrium, endometriosis and 
from peritoneal mesothelium (9). Alternatively, these cells may not be derived from the endometrium and hence not have been shed by retrograde menstruation into the peritoneal cavity. However, intact mesothelium is an unlikely source of these free-floating epithelial cells, because mesothelial cells have only been found in the peritoneal fluid after damage of the peritoneal lining. Furthermore, we cannot exclude the potential origin of the epithelial cells from microscopic endometriotic implants, because these cells would probably show the same epithelial marker expression.

In conclusion, our study shows that peritoneal fluid contains single epithelial cells, rather than endometrial tissue fragments in women with patent tubes. Possibly endometrial epithelial cells are modulated in the peritoneal cavity after they have left the uterine cavity prior to become an endometriotic lesion. Our study supplies new evidence for the contention of reflux menstrual detritus playing an important role in the development of endometriosis in women with patent tubes.

\section{Acknowledgements}

The authors thank Dr. Lambert G. Poels (Department of Cell Biology and Histology, University of Nijmegen, The Netherlands) for providing the monoclonal antibody BW495/36. 


\section{References}

1. Sampson JA. Peritoneal endometriosis due to the menstrual dissemination of endometrial tissue into the peritoneal cavity. Am J Obstet Gynecol 1927; 14: 422-469.

2. Sampson JA. The development of the implantation theory for the origin of peritoneal. endometriosis. Am J Obstet Gynecol 1940; 40: 549-557.

3. Haney AF. The pathogenesis and aetiology of endometriosis. In: Thomas EJ, Rock JA, eds. Modern approaches to endometriosis. Dordrecht, Boston, London: Kluwer Academic Publisher, 1991: 3-19.

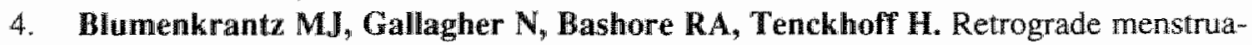
tion in women undergoing chronic peritoneal dialysis. Obstet Gynecol 1981, 57: 667670.

5. Halme I, Hammond MG, Hulka JF, Raj SG, Talbert LM. Retrograde menstruation in healthy women and in patients with endometriosis. Obstet Gynecol 1984; 64: 151-154.

6. Beyth X, Yaffe H, Levij IS, Sadovsky E. Retrograde seeding of endometrium: a sequela of tubal flushing. Fertil Steril 1975; 26: 1094-1097.

7. Bartosik D, Jacobs SL, Kelly LJ. Endometrial tissue in peritoneal fluid. Fertil Steril 1986; 46: 796-800.

8. Kulenthran A, Jeyalakshmi N. Dissemination of endometrial cells at laparoscopy and chromotubation. A preliminary report. Int J Fertil 1989; 34: 256-258.

9. Kruitwagen RFPM, Poels LG, Willemsen WNP, de Ronde IJY, Jap PHK, Rolland R. Endometrial epithelial cells in peritoneal fluid during the early follicular phase. Fertil Steril 1991; 55: 297-303.

10. Badawy SZA, Cuenca V, Marshall L, Munchback R, Rinas AC, Coble DA. Cellular components in peritoneal fluid in infertile patients with and without endometriosis. Fertil Steril 1984; 42: 704-707.

11. Koninckx PR, Ide P, Vandenbroucke W, Brosens IA. New Aspects of the pathophysiology of endometriosis and associated infertility. J Reprod Med 1980; 24: 257-260.

12. The American Fertility Society. Revised American Fertility Society classsification of endometriosis: 1985. Fertil Sterill 1985; 43: $351-352$.

13. van Niekerk CC, Ramaekers FCS, Hanselaar AGJM, Aldeweireldt J, Poels LG. Changes in expression of differentiation markers between normal ovarian cells and derived tumors. Am J Pathol 1993; 142: 157-177.

14. Kruitwagen RFPM, Poels LG, Willemsen WNP, Jap PH, de Ronde IJ, Hanselaar TG, Rolland R. Immunocytochemical marker profile of endometriotic epithelial, endometrial epithelial, and mesothellial cells: a comparative study. Eur J Obstet Gynecol Reprod Biol 1991; 41:215-223.

15. Reti LL, Byrne GD, Davoren RAM. The acute clinical features of retrograde menstruation. Aust N Z J Obstet Gynaec 1983; 23: $51-52$.

16. Oosterlynck DJ, Meuleman C, Waer M, Vandeputte M, Koninckx PR. The natural killer activity of peritoneal fluid lymphocytes is decreased in women with endometriosis. Fertil Steril 1992; 58: 290-295.

17. Willemsen WNP, Mungyer G, Smets $\mathbf{H}$, Rolland $\mathbf{R}$, Vemer H, Jap P. Behavior of cultured glandular cells obtained by flushing of the uterine cavity. Fertil Steril 1985; 44: 92-95. 


\section{Chapter 4}

\section{Expression of integrins and E-cadherin in cells from menstrual effluent, endometrium, peritoneal fluid, peritoneum and endometriosis}

P.J.Q. van der Linden, A.F.P.M. de Goeij, G.A.J. Dunselman, E.P.M. van der Linden, F.C.S. Ramaekers and J.L.H. Evers

Fertility and Sterility 1994; 61: 85-90

(reprinted with permission) 


\section{Abstract}

Objective: To detect the expression of integrins and E-cadherin in cells from peritoneal fluid, endometrium, menstrual effluent, peritoneum and endometriotic lesions during the early follicular phase of the menstrual cycle.

Design: An immunohistochemical study.

Setting: Tertiary-care university medical center.

Patients: Sixteen patients undergoing a diagnostic laparoscopy as part of a subfertility work-up. All patients had regular and ovulatory cycles.

Interventions: A laparoscopy was performed in the early follicular phase (day 2 to 5). Simultaneously, samples were taken from endometrium, menstrual effluent and peritoneal fluid and a representative biopsy of an endometriotic lesion was obtained. If endometriosis was not noted, a peritoneal biopsy was obtained instead.

Main Outcome Measures: The expression of cell adhesion molecules, including the integrin $\alpha 2 \beta 1, \alpha 3 \beta 1, \alpha 4 \beta 1, \alpha 5 \beta 1$ and $\alpha 6 \beta 1$ and E-cadherin, as determined by immunohistochemistry on frozen sections.

Results: All integrins tested could be detected in the endometrium samples and in endometriotic lesions. In menstrual effluent samples, positive staining for the integrins $\alpha 2 \beta 1$ and $\alpha 3 \beta 1$ was found in epithelial cells of 13 of 16 cases. Integrin $\alpha 5 \beta 1$ was detected in 11 of 16 samples and integrins $\alpha 4 \beta 1$ and $\alpha 6 \beta 1$ were detected in 5 of 16 samples. In peritoneal fluid, integrin $\alpha 3 \beta 1$ was found in epithelial cells in 12 of 16 samples, integrin $\alpha 5 \beta 1$ in 5 of 16 , integrins $\alpha 4 \beta 1$ and $\alpha 6 \beta 1$ in 2 of 16 . The antibody for E-cadherin showed positive staining of epithelial cells in 6 of 16 menstrual effluent samples. All endometrial tissue samples showed positive staining for E-cadherin. In peritoneal fluid, E-cadherin was detected in the epithelial cells of one sample. One peritoneum biopsy revealed positive staining for E-cadherin.

Conclusion: Integrins $\alpha 2 \beta 1, \alpha 3 \beta 1, \alpha 4 \beta 1, \alpha 5 \beta 1$, and $\alpha 6 \beta 1$ and E-cadherin, important cell adhesion molecules, are expressed in endometriotic lesions and in cells and tissues that are potentially involved in the development of endometriosis. These cell adhesion molecules could be involved in the shedding of endometrial tissue during menstruation and the attachment of endometrial tissue fragments to the peritoneum.

\section{Introduction}

Retrograde menstruation and peritoneal adhesion of shedded endometrial tissue is an essential element in the pathogenesis of endometriosis, according to Sampson's classical implantation theory (1-3). The presence of endometrial tissue fragments in peritoneal fluid during the early follicular phase of the cycle 
of women with patent tubes has been demonstrated (4). As has been shown before, early endometriosis is invading the extracellular matrix; however, the mechanism of adhesion of endometrial tissue to the peritoneum is not clear (5). We assume that cell adhesion molecules, such as integrins and cadherins may be involved in adhesion of endometrial fragments, which are present in the peritoneal fluid, to the peritoneum. Integrins are a family of cell membrane glycoproteins consisting of an $\alpha$ and a $\beta$ subunit that mediate celli-cell and cell-matrix adhesion $(6,7)$. Currently more than 20 integrin heterodimers are known, which are composed of one of at least fourteen different $\alpha$ and one of eight different $\beta$ chains (8). The majority of the integrins presently known bind to various extracellular matrix components and mediate cell-matrix interactions during cell adhesion to basement membranes and other extracellular matrices and during cell migration $(8,9)$. Some integrins are also involved in cell-cell adhesion, i.e. the subunits $\alpha 2$ and $\alpha 3$ (10). The largest number of integrins are members of the $\beta 1$ or very late activation antigen subfamily $(6,8)$. The integrins of the $\beta 1$ family, with $\alpha$ chains $\alpha 1$ to $\alpha 6$ serve as receptors for matrixproteins laminin ( $\alpha 1$ to $3, \alpha 6)$, fibronectin ( $\alpha 3$ to 5 ), and type IV collagen ( $\alpha 1$ to 3 ) $(8,9,11,12)$. The distribution pattern of the integrins in tissues, and how these patterns are affected by disease, is relatively unknown, in particular with respect to the female genital tract. The cells of most tissues express $\alpha 1 \beta 1, \alpha 2 \beta 1, \alpha 3 \beta 1$ and $\alpha 6 \beta 1$. The integrin $\alpha 5 \beta 1$ is expressed to a lesser extent in most tissues.

Cadherins belong to a group of calcium-dependent transmembrane glycoproteins (13). Each cadherin type has a unique but wide tissue distribution that may vary during different stages of development. Cadherins mediate cell-cell. interaction. Adhering processes, which involve cadherins are homopliylic. Cells adhere preferentially to cells which express the same cadherin. Cadherins are important constituents of adherens junctions where they are responsible for cytoskeletal organization. E-cadherin (also known as Arc-1, uvomorulin, and cell-CAM 120/80) is expressed in all proliferating epithelial cells derived from the ectoderm and the entoderm. Neural and mesodermal tissues do not express E-cadherin, with the exception of some components of the urogenital system and some mesothelial layers (13). E-cadherin is expressed in the cell-to-cell-boundaries of the endometrium (14). Cadherins play an important role in invasive processes and metastasis of tumor cells $(12,15-17)$. At present, the potential role of cell adhesion molecules in the development of endometriosis is largely unknown. If the assumption is correct that integrins and cadherins account for adhesion of endometrial cells to peritoneum, which may lead to endometriosis, these cell adhesion molecules should be expressed on endometrial cells that are shed into the peritoneal cavity. Therefore our aim was to study the expression of cell adhesion molecules on cells, which are potentially involved in the development of endometriosis. To this end the expression of integrins and E-cadherin was detected using immunohistochemistry on cells present in peri- 
toneal fluid, the endometrium, menstrual effluent, peritoneum and endometriotic lesions in the early follicular phase of the menstrual cycle.

\section{Materials and methods}

Sixteen patients underwent a diagnostic laparoscopy as part of a subfertility work-up. All patients involved gave informed consent. All women had a regular and ovulatory cycle, as demonstrated by ultrasound and an adequate rise in serum progesterone in the luteal phase of the cycle. The laparoscopy, using a double puncture technique, was performed in the early follicular phase (day 2 to day 5). At the start of the laparoscopy menstrual effluent was collected from the vagina using a syringe. A sample of endometrium was obtained by using a Probet endometrial sampling device (Gynetics, Oisterwijk, The Netherlands). Peritoneal fluid was collected immediately after introduction of the second trocar. Subsequently a representative biopsy of an endometriotic lesion was obtained using a biopsy forceps and in two patients an additional biopsy was obtained from unaffected peritoneum. When endometriosis was identified, it was staged according to the revised American Fertility Society (AFS) classification (18). When no endometriosis was diagnosed, a peritoneal biopsy was obtained from the pouch of Douglas. The samples of menstrual effluent and endometrium were frozen in isopentane, immersed in dry ice. The tissue biopsies were embedded in Tissue Tek OCT compound (Miles Scientific, Elkhart, IN) and also frozen immediately. The peritoneal fluid samples were centrifuged for 5 minutes. After removal of the supernatant, the pellet was frozen in isopentane in dry ice. All samples were stored at $-70^{\circ} \mathrm{C}$ until analyzed.

Cryostat sections of $4 \mu \mathrm{m}$ thick were prepared and mounted on slides. The sections were air dried and fixed with methanol at $-20^{\circ} \mathrm{C}$ for 1 minute, followed by an acetone dip at $-20^{\circ} \mathrm{C}$. Slides were washed three times for 5 minutes in phosphate-buffered saline (PBS), and immersed in $0.3 \%$ hydrogen peroxide to block endogenous peroxidase activity. The sections were washed again three times for 5 minutes in PBS. A series of mouse monoclonal antibodies was used including L-CAM for E-cadherin (Euro-Diagnostica B.V., Apeldoom, The Netherlands, IOG 1 for integrin $\alpha 2 \beta 1, J 143$ for $\alpha 3 \beta 1, \mathrm{HP} 2 / 1$ for integrin $\alpha 4 \beta 1$ and SAM-1 for $\alpha 5 \beta 1$ respectively. Also the rat monoclonal antibody $\mathrm{GOH} 3$ for $\alpha 6 \beta 31$ was applied. Incubation with primary antibodies against integrins and cadherin was done in appropriate dilutions for 60 minutes at room temperature. For staining with the mouse monoclonal antibodies a streptavidin-biotin complex method was used. After washing three times for 10 minutes in PBS, the sections were incubated for 30 minutes with biotin-labeled sheep anti-mouse immunoglobulin(Ig)G (Amersham Nederland B.V., Den Bosch, The Nether- 
lands). After washing in PBS, the sections were incubated with a streptavidinbiotin-peroxidase complex (Dako A/S, Glostrup, Denmark) for 30 minutes. For staining with the rat monoclonal antibody $\mathrm{GOH} 3$ the slides were washed three times for 10 minutes and then incubated for 60 minutes with rabbit anti-rat IgG conjugated with horseradish peroxidase (Dako A/S, Glostrup, Denmark). Antibody binding was visualized using 3'-3-diaminobenzidine and hydrogen peroxide. The slides were counterstained with hematoxylin, and stained slides were dehydrated through alcohols, cleared in xylene, and mounted in Entellan for light microscopy. Positive staining was defined as immunoreactivity at the periphery of the cell. Negative controls included sections stained without the primary antibody, using PBS instead. Positive controls consisted of known positive samples of colon and endometrium.

\section{Results}

Endometriosis was identified visually and confirmed histologically in eight patients and classified as stage I according to the revised AFS classification. All patients had patent tubes. In all peritoneal fluid samples a red color was noted and red blood cells were identified. Table 1 summarizes the results of the immunohistochemical staining with the various monoclonal antibodies against integrins in menstrual effluent, endometrium, peritoneal tluid, peritoneum and endometriotic lesions. Figure $1 \mathrm{~A}$ to $\mathrm{G}$ illustrates the staining patterns of the various monoclonal antibodies used.

Ten peritoneal biopsies were tested: 8 from patients without endometriosis and 2 from patients who also had endometriotic lesions biopsied.

Antibodies against integrins $\alpha 2 \beta 1, \alpha 3 \beta 1$, showed positive staining in the menstrual effluent samples from 13 patients. Integrin $\alpha 5 \beta 1$ was detected in 11 of 16 samples. The integrins $\alpha 4 \beta I$ and $\alpha 6 \beta 1$ were found in only 5 of 16 samples. No relation was found between the presence or absence of these two in individual patients. In the endometrium samples all integrins could be detected. Immunohistochemistry with anti-integrin $\alpha 4 \beta 1$ demonstrated heterogenous staining. In the individual endometrial samples positively as well as negatively stained glands were observed. Furthermore, $\alpha 4 \beta 1$ was only detected in 12 of 16 cases.

In peritoneal fluid, integrin $\alpha 3 \beta 1$ was found in epithelial cells in 12 of 16 samples, whereas integrins $\alpha 4 \beta 1$ and $\alpha 6 \beta 1$ were only found in 2 of 16 . In one case this was in the same patient. Integrin $\alpha 4 \beta 1$ was not expressed in the epithelial cells of patients without endometriosis, but was present in 2 of 8 patients with endometriosis. No differences between patients with and patients without endometriosis were found in the expression of the other integrins on the 


\section{Table 1}

Immunohistochemistry of integrins of cells from menstrual effluent, endometrium, peritoneal fuid, peritoneum and endometriotic lesions in 16 women with and without endometriosis. Number of cases with positive staining over number of cases tested.

\begin{tabular}{|c|c|c|c|c|c|c|}
\hline \multirow[b]{2}{*}{ Tissue } & \multirow[b]{2}{*}{ Endometriosis } & \multicolumn{5}{|c|}{ Monoclonal antibody/antigen } \\
\hline & & $\begin{array}{l}10 G 11 \\
\alpha 2 \beta 1\end{array}$ & $\begin{array}{l}J 143 \\
\alpha 3 \beta 1\end{array}$ & $\begin{array}{l}\mathrm{HP} 2 / 1 \\
\alpha A \beta 1\end{array}$ & $\begin{array}{l}\text { SAMI } \\
\alpha 5 \beta 1\end{array}$ & $\begin{array}{l}\text { GOH3 } \\
\alpha 6 \beta 1\end{array}$ \\
\hline Menstrual & + & $7 / 8$ & $7 / 8$ & $2 / 8$ & $7 / 8$ & $2 / 8$ \\
\hline effluent & - & $6 / 8$ & $6 / 8$ & $3 / 8$ & $4 / 8$ & $3 / 8$ \\
\hline \multirow[t]{2}{*}{ Endometrium } & + & $8 / 8$ & $7 / 8$ & $7 / 8$ & $8 / 8$ & $8 / 8$ \\
\hline & - & $8 / 8$ & $7 / 8$ & $5 / 8$ & $8 / 8$ & $8 / 8$ \\
\hline Peritoneal & + & $2 / 8$ & $7 / 8$ & $2 / 8$ & $5 / 8$ & $1 / 8$ \\
\hline fluid & - & $3 / 8$ & $5 / 8$ & $0 / 8$ & $5 / 8$ & $1 / 8$ \\
\hline \multirow[t]{2}{*}{ Peritoneum } & + & $0 / 2$ & $0 / 2$ & $0 / 2$ & $0 / 2$ & $0 / 2$ \\
\hline & - & $4 / 8$ & $6 / 8$ & $1 / 8$ & $6 / 8$ & $3 / 8$ \\
\hline $\begin{array}{l}\text { Endometriotic } \\
\text { lesion }\end{array}$ & + & $7 / 8$ & $7 / 8$ & $3 / 8$ & $5 / 8$ & $5 / 8$ \\
\hline
\end{tabular}

epithelial cells in peritoneal fluid. In endometriotic lesions all tested integrins could be cletected. Integrin $\alpha 5 \beta 1$ did not show reactivity in two cases which were stained positively for $\alpha 2 \beta 1, \alpha 3 \beta 1$ and $\alpha 6 \beta 1$ and in one case which did not reveal positive staining for any of the other integrins tested, except for $\alpha 4 \beta 1$. Integrin $\alpha 4 \beta 1$ was found in 3 of 8 samples.

Table 2 summarizes the results of the immunohistochemical staining patterns with the anti-E-cadherin monoclonal antibody in menstrual effluent, endometrium, peritoneal fluid, peritoneum and endometriotic lesions. Figure $1 \mathrm{H}$ illustrates the staining pattern. The antibody for E-cadherin showed positive staining of epithelial cells in six menstrual effluent samples: three from patients with and three from patients without endometriosis. All endometrial tissue samples showed positive staining for E-cadherin. In peritoneal fluid, E-cadherin 

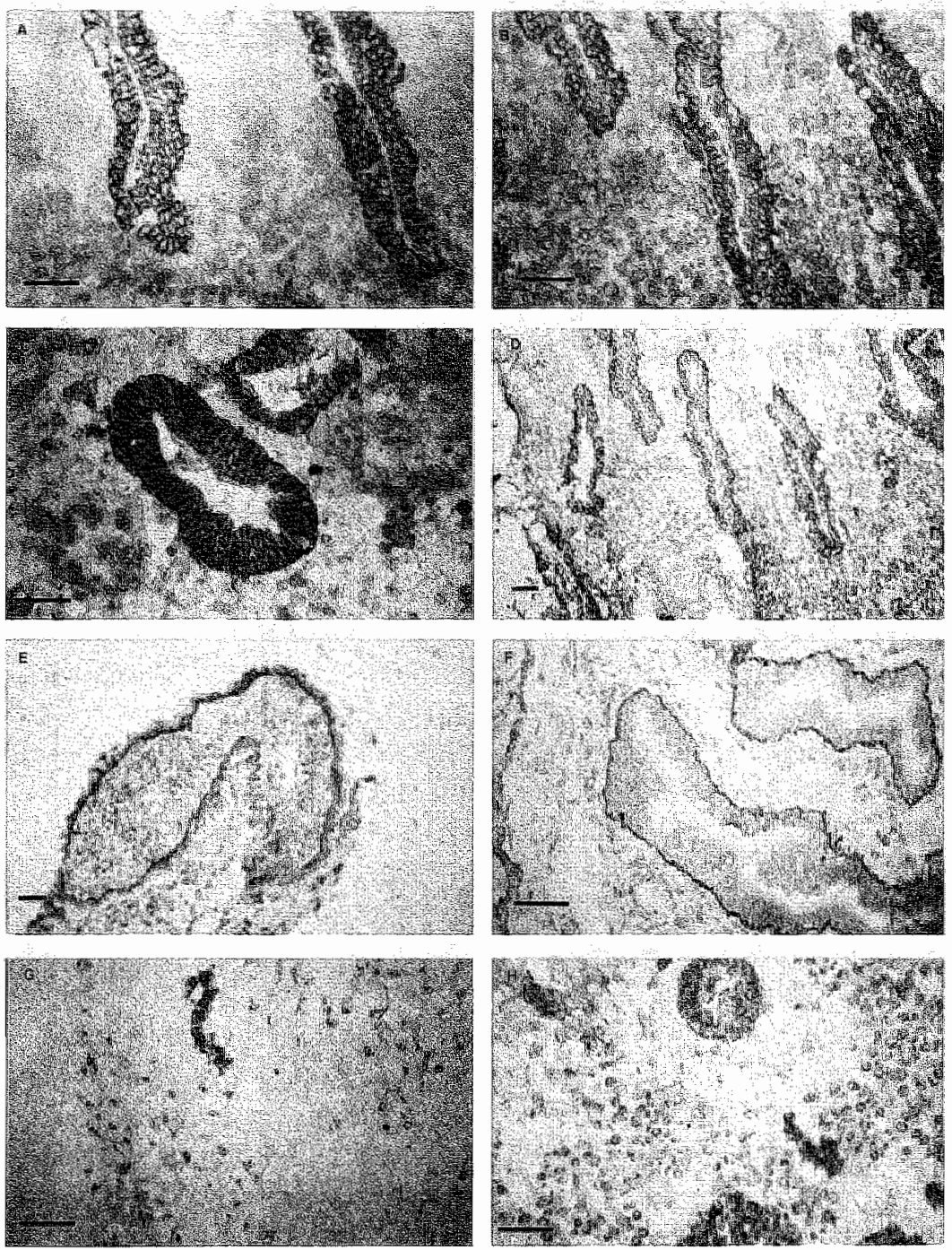

Figure 1

Staining patterns of various samples after incubation with monoclonal antibodies.

A. endometrium stained for integrin $\alpha 2 \beta \|$ with $10 G \| 1$, B. endometrium stained for integrin $\alpha 3 \beta 1$ with $\mathrm{J} 143$, C. endometrium stained for $\alpha 4 \beta 1$ with $\mathrm{HP} 2 / 1, \mathrm{D}$. endometrium stained for $\alpha 5 \beta 1$ with SAM-1, E. menstrual effluent, containing a glandular structure stained for integrin $a 6 \beta 1$ with $\mathrm{GOH} 3, \mathrm{~F}$. endometriosis stained for integrin $\alpha 6 \beta 1$ with $\mathrm{GOH} 3, \mathrm{G}$, epithelial cells in peritoneal fluid stained for integrin $\alpha 5 \beta 1$ with SAM-1 , H. endometrium stained for E-cadherin with L-CAM. Bar indicates $55 \mu$. Original magnification: $\times 100$. 
Immunohistochemistry of E-cadherin with cells from menstrual effluent, endometrium. peritoneal fluid, peritoneum and endometriotic lesions in 16 women with and without endometriosis. Number of cases with positive staining over number of cases tested.

Monoclonal antibody/antigen

Tissue

Endometriosis

L-CAM

E-cadherin

Menstrual effluent

$+\quad 3 / 8$

- $3 / 8$

Endometrium

$+8 / 8$
$+\quad 8 / 8$

Peritoneal fluid

\begin{tabular}{ll}
$+\quad 1 / 8$ \\
\hline
\end{tabular}

$\begin{array}{ll}+ & 0 / 8\end{array}$

Peritoneum

$0 / 2$
$+\quad 1 / 8$

$\begin{array}{ll}+ & 1 / 8\end{array}$

Endometriotic lesion

$+$

$2 / 8$

was detected in the epithelial cells of only one sample. In this particular patient $\mathbb{E}$-cadherin was also found in the endometrium and in an endometriotic lesion, but not in a sample of menstrual effluent. In another patient, E-cadherin staining was detected in the endometriotic lesion, but was absent in menstrual effluent and peritoneal fluid. Only one peritoneum biopsy revealed positive staining for E-cadherin. The two biopsies from patients with endometriosis did not show positive staining for E-cadherin. 


\section{Discussion}

Retrograde menstruation is considered an important factor in the development of endometriosis. Pathogenetically, endometrial tissue, which is shed into the abdominal cavity, should adhere to the peritoneal lining. The present study demonstrates the presence of integrins and cadherins, in cells and tissues that are potentially involved in the development of endometriosis, and in endometriosis itself. In endometrium, all integrins that were tested could be detected. This is in accordance with a study of Tabibzadeh (12). Integrin $\alpha 4 \beta 1$ was found to be expressed in the endometrium during the early follicular phase of the menstrual cycle and in a gland-to-gland variation. Tabibzadeh (12) could detect integrin $\alpha 4 \beta 1$ only in the glandular epithelium in the midproliferative and midsecretory phases. Lessey and coworkers found $\alpha 1$, an integrin we did not test, only to be present during the secretory phase of the menstrual cycle on glandular epithelial cells and a uniform expression of $\alpha 2, \alpha 3$, and $\alpha 6$ throughout the cycle was noted (10). In contrast to our results integrin $\alpha 4 \beta 1$ was not found in either phase of the cycle in their study and the $\alpha 5$ subunit only was found in the mesenchyme, which is rich in fibronectin. Epithelial cells in menstrual effluent did express integrins. Integrin $\alpha 4 \beta 1$ and $\alpha 6 \beta 1$ were less frequently found, and in peritoneal fluid this effect was even more pronounced. Both cases that showed positive expression for $\alpha 4 \beta 1$ revealed endometriosis, whereas in none of the cases without endometriosis $\alpha 4 \beta 1$ was found. This suggests a potential role for integrin $\alpha 4 \beta 1$ in endometriosis, but the small number of cases does not allow definite conclusions.

All endometrial samples showed E-cadherin expression. The epithelial cells in menstrual effluent revealed E-cadherin expression to a lesser extent. No major differences were found between patients with and patients without endometriosis. The peritoneum samples only showed E-cadherin expression in one case. This suggests that E-cadherin does not play a prominent role in an adhesion process leading to the development of endometriosis.

The finding in our study that the cells in peritoneal fluid showed less reactivity with monoclonal antibodies against E-cadherin and the integrins $\alpha 4 \beta 1$ and $\alpha 6 \beta 1$ than to the other cell adhesion molecules is confusing. One explanation could be that cells of the endometrium in order to be shed lose their expression of certain cell adhesion molecules. To our knowledge, no data exist on a possible cycle dependency of $E$-cadherin expression, as is found for integrin $\alpha 4 \beta 1$. E-cadherin expression may be temporarily decreased, only to be re-expressed once the endometriotic lesion has been organized. From cancer research it is known that when E-cadherin expression is lost, cells lose their interconnection and shed to invade (16). Integrins may also be involved in tumor invasion and metastasis. Malignant transformation is associated with a change in integrin expression (6). 
Well-differentiated tumors tend to express more E-cadherin than less differentiated tumors. A comparable mode of E-cadherin expression behavior in the processes involved in the menstrual shedding of endometrium is, however, not a satisfactory explanation for the finding of E-cadherin expression in only 1 of 16 cases in epithelial cells of peritoneal fluid, on the one hand, and in 6 of 16 samples of menstrual effluent on the other hand. Another explanation could be a technical artifact. When applying an antibody directed against the intermediate filament proteins such as cytokeratins, important constituents of the intracellular cytoskeleton, a strong staining intensity throughout the cytoplasm of the cell can be expected. The reactivity of E-cadherin is, however, limited to the cellular boundaries. The integrin $\alpha 6 \beta 1$ is expressed at the basolateral surface of the cell, and hence gives a subtle signal when seen on a single cell (Fig. 1).

The demonstration of cell adhesion molecules in menstrual effluent, endometrium, peritoneal fluid, as well as in endometriotic lesions, is no strict evidence that endometriosis originates from endometrium by retrograde shedding of viable tissue fragments. The expression pattern of cell adhesion molecules indicates that the loss of cell adhesion properties may play a role in the shedding of endometrial tissue during menstruation and in the attachment of endometrial tissue fragments to the peritoneum. Effective cellular adhesion requires that a given cell coordinates the action of the various adhesion molecules. It is, therefore, not to be expected that the processes involved in the adhesion of shed endometrial tissue in the pathogenesis of endometriosis can be explained by the presence or absence of one single cell adhesion molecule expression. Alternately, it is possible that other cell adhesion molecules that we did not study play a role in determining which endometrial tissues wil adhere and proliferate.

In conclusion, the present study shows that all cells that are involved in the pathogenesis of endometriosis, possess the property to express cell adhesion molecules. Although the pattern of integrins expressed by cultured cells is not always identical to that expressed by the same cells in their tissue of origin, it is mandatory to study the adhesion process involved in the pathogenesis of endometriosis both in vivo and in vitro.

\section{Acknowledgements}

The authors wish to thank Arnoud Sonnenberg, Ph.D. (Central Laboratory of The Netherlands Red Cross Transfusion Service, Amsterdam, The Netherlands) for providing the monoclonal antibodies IOG 1 1, J 143 and GOH3 and Carl Figdor, Ph.D. (The Netherlands Cancer Institute, Amsterdam, The Netherlands) for providing the monoclonal antibodies HP2/1 and SAM-1. 


\section{References}

1. Sampson JA. Peritoneal endometriosis due to the menstrual dissemination of endometrial tissue into the peritoneal cavity. Am J Obstet Gynecol 1927; 14: 422-469.

2. Sampson JA. The development of the implantation theory for the origin of peritoneal endometriosis. Am J Obstet Gynecol 1940; 40: 549-557.

3. Haney AF. The pathogenesis and aetiology of endometriosis. In: Thomas EJ, Rock IA, editors. Modern approaches to endometriosis. Dordrecht, Boston, London: Kluwer Academic Publisher, 1991: 3-19.

4. Kruitwagen RFPM, Poels LG, Willemsen WNP, de Ronde IJY, Jap PHK, Rolland R. Endometrial epithelial cel ls in peritoneal fuid during the early follicular phase. Fertil Steril 1991; 55: 297-303.

5. Spuijbroek MDEH, Dunselman GAJ, Menheere PPCA, Evers ILH. Early endometriosis invades the extracellular matrix. Fertil Steril 1992; 58:929-933.

6. Albelda SM, Buck CA. Integrins and other cell adhesion molecules. FASEB J 1990; 4: 2868-2880.

7. Ruoslahti E. Integrins. J Clin Invest 1991; 87: 1-5.

8. Hynes RO. Integrins: Versatility, modulation, and signaling in cell adhesion. Cell 1992; 69: $11-25$.

9. Hynes RO, Lander AD. Contact and adhesive specificities in the associations, migrations and targeting of cells and axons. Cell 1992; 68:303-322.

10. Lessey BA, Damjanovich L, Coutifaris C, Castelbaum A, Albelda SM, Buck CA. Integrin adhesion molecules in the human endometrium. Correlation with the normal and abnormal menstrual cycle. J Clin Invest 1992; 90: 188-195.

11. Katz AM, Rosenthal D, Sauder DM. Cell adhesion molecules. Structure, function and implication in a variety of cutaneous and other pathologic conditions. Int J Dermatol 1991; 30: $153-160$.

12. Tabibzadeh $\mathbf{S}$. Patterns of expression of integrin molecules in human endometrium throughout the menstrual cycle. Hum Reprod 1992; 7: 876-882.

13. Takeichi M. The cadherins: cell-cell adhesion molecules controlling animal morphogenesis. Development 1988; 102: 639-655.

14. Inoue $\mathbf{M}$, Ogawa H, Miyata $\mathbf{M}$, Shiozaki H, Tanizawa $\mathbf{O}$. Expression of E-cadherin in normal, benign, and malignant tissues of female genital organs. Am J Clin Pathol 1992; $98: 76-80$.

15. Frixen UH, Behrens J, Sachs M, Eberle G, Voss B, Warda A, Löchner D, Birchmeier W. E-Cadherin mediated cell-cell adhesion prevents invasiveness of human carcinoma cells. J Cell Biol 1991; 113: 173-185.

16. Vlemminckx K, Vakaet L, Mareel M, Fiers W, van Roy F. Genetic manipulation of E-Cadherin expression by epithelial tumor cells reveals an invasion suppressor role. Cell 1991; 66: 107-119.

17. Hashimoto M, Niwa O, Nitta Y, Takeichi M, Yokoro K. Unstable expression of E-Cadherin adhesion molecules in metastatic ovarian tumor cells. Jpn J Cancer Res $1989 ; 80: 459-463$.

18. The American Fertility Society. Revised American Fertility Society classsification of endometriosis: 1985. Fertil Steril 1985; 43:351-352. 



\section{Chapter 5}

\section{P-cadherin expression in human endometrium and endometriosis}

P.J.Q. van der Linden, A.F.P.M. de Goeij, G.A.J. Dunselman, J.W. Arends and J.L.H. Evers

Gynaecologic and Obstetric Investigation 1994; 38: 183-185

(reprinted with permission) 


\section{Abstract}

The objective of the present study was to detect the expression of P-cadherin in human endometrium and endometriosis and to compare this expression to that of E-cadherin. To this end immunohistochemistry with monoclonal antibodies specific for P-cadherin and E-cadherin was applied to endometrium and endometriotic lesions obtained in the early follicular phase of the menstrual cycle from ten patients. P-cadherin was detected in epithelial cells in all ten endometrial samples and in all glandular structures of endometriotic lesions. The staining characteristics for P-cadherin and E-cadherin were similar. P-cadherin may play a role in the maintenance of the proliferative compartment of endometrium and could have a comparable function in endometriotic lesions.

\section{Introduction}

Cadherins belong to a group of calcium-dependent transmembrane glycoproteins that mediate homophylic cell-cell interaction (1). Cells adhere preferentially to cells which express the same type of cadherin subclass. Each subclass of these cell adhesion molecules, including $\mathrm{E}-\mathrm{N}$ - and $\mathrm{P}$ - cadherin, has a unique but wide tissue distribution that may vary during different stages of embryonic development (2). Cadherins are important constituents of adherence junctions. In an earlier study we have demonstrated E-cadherin expression during the early follicular phase of the cycle in human endometrium and to a lesser extent in endometriosis (3). A potential role of cell adhesion molecules such as E-cadherin in the development of endometriosis was suggested.

P-cadherin was first identified in mouse placental tissue as a molecule connecting the embryo to the uterine wall $(4,5)$. Human P-cadherin is highly homologous in amino acid sequence with mouse P-cadherin, but it differs in at least one important respect: it is immunohistochemically not detectable in human placental tissue. P-cadherin was detected in basal or lower layers of stratified epithelia only, and not in simple epithelia (5). To our knowledge no reports on the expression of P-cadherin in human endometrium and endometriosis have been published so far.

Our aim was to study the expression of P-cadherin in human endometrium and endometriosis and to compare this expression to that of E-cadherin. To this end immunohistochemistry with monoclonal antibodies specific for P-cadherin and $E$-cadherin was applied in endometrium and endometriotic lesions obtained in the early follicular phase of the menstrual cycle. 


\section{Materials and methods}

Samples from endometrium and endometriotic lesions were collected from 10 patients with endometriosis. All patients gave informed consent. All women had a regular and ovulatory cycle, as demonstrated by ultrasound and an adequate rise in serum progesterone in the luteal phase of the cycle. Laparoscopy was performed in the early follicular phase (day 2 to 5) using a double puncture technique. A sample of endometrium was obtained by using a Probet endometrial sampling device (Gynetics, Oisterwijk, The Netherlands). Subsequently, during the laparoscopy, representative biopsies of endiometriotic lesions were obtained using a biopsy forceps. The samples of endometrium were snap-frozen in isopentane and immersed in dry ice. The biopsies of endometriotic lesions were embedded in Tissue Tek OCT compound (Miles Scientific, Elkhart, Ind., USA) and also frozen immediately in isopentane. All samples were stored at $-70^{\circ} \mathrm{C}$ until analyzed.

\section{Immunohistochemical Staining Procedures}

Cryostat sections of $4 \mu \mathrm{m}$ thickness were prepared and mounted on slides. Each slide contained three serial sections. The sections were air-dried and fixed with methanol at $-20^{\circ} \mathrm{C}$ for 1 minute, followed by an acetone dip at $-20^{\circ} \mathrm{C}$. Slides were washed 3 times during 5 minutes in phosphate-buffered saline (PBS), and immersed in $0.3 \%$ hydrogen peroxide to block endogenous peroxidase activity. The sections were washed again 3 times for 5 minutes in PBS and then preincubated with diluted normal sheep serum (1:10) for 10 minutes. NCCCAD-299, a mouse monoclonal antibody was used to stain for P-cadherin (4). The monoclonal antibody L-CAM (Euro-Diagnostica B.V., Apeldoorn, The Netherlands) was used for E-cadherin. Incubation with primary antibodies against $\mathrm{P}$-cadherin and $\mathrm{E}$-cadherin was done in an appropriate dilution (1:4 and 1:20 respectively) for 16 hours at room temperature. After washing 3 times for 10 minutes in PBS, the sections were incubated for 30 minutes with biotinlabeled sheep anti-mouse Immunoglobulin G (Amersham Nederland B.V., Den Bosch, The Netherlands). After washing in PBS, the sections were incubated with a streptavidin-biotin-peroxidase complex (Dako A/S, Glostrup, Denmark) for 30 minutes. Antibody binding was visualized using 3'-3-diaminobenzidine and hydrogen peroxide. The slides were counterstained with hematoxylin, dehydrated through alcohols, cleared in xylene and mounted in Entellan for light microscopy. Positive staining was defined as immunoreactivity at the periphery of the cells. Negative controls included sections stained without the primary antibody, using PBS instead. Positive controls consisted of known positive samples of bronchial epithelium and skin for P-cadherin and samples of endometrium and colon for E-cadherin. 


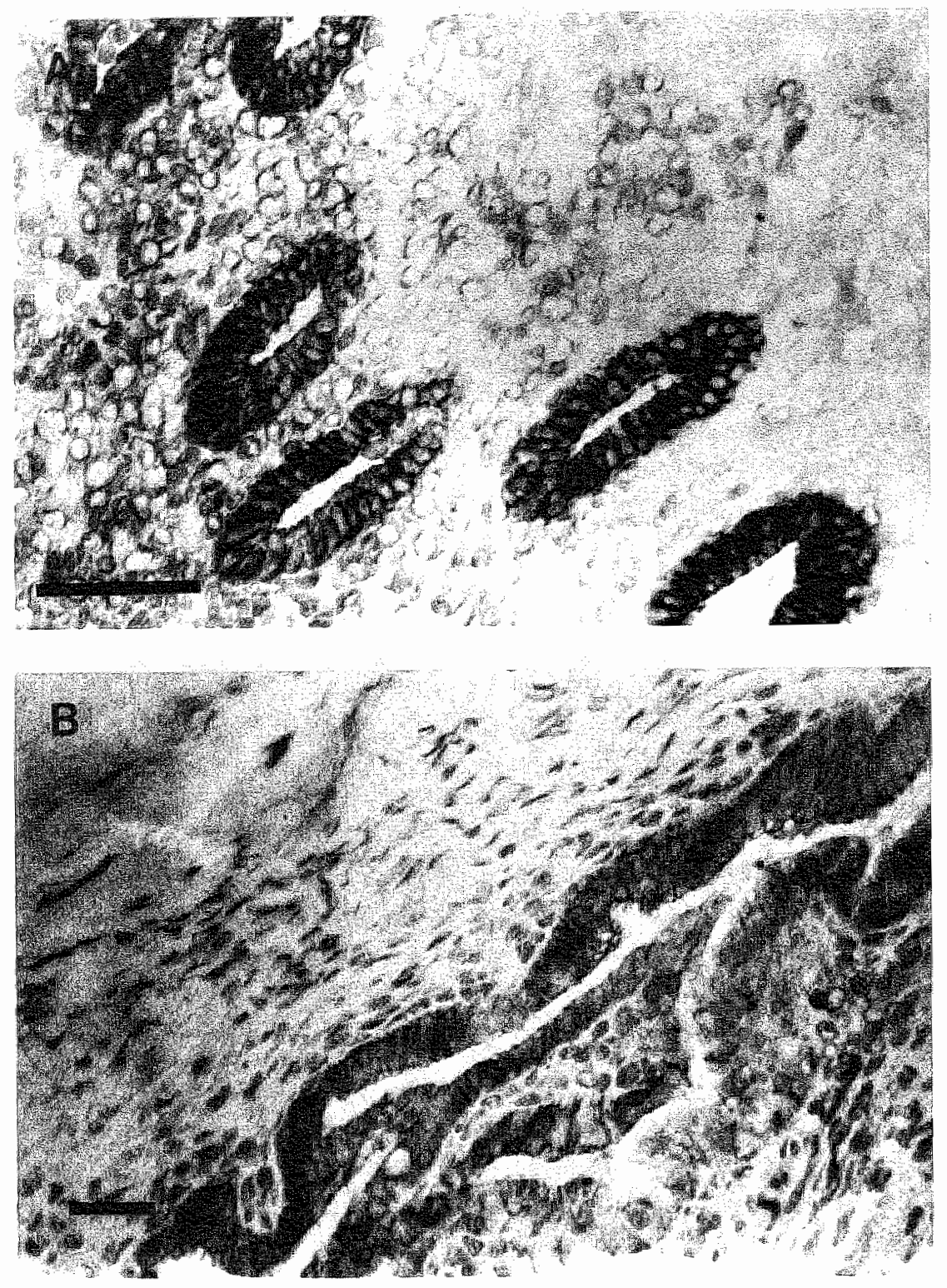

\section{Figure 1}

Staining pattern of a sample of endometrium and a sample of endometriosis after incubation with monoclonal antibody NCC-CAD-299 for P-cadherin.
A. endometrium B. endometriosis
Bar indicates: $55 \mu$ 


\section{Results}

P-cadherin was detected in epithelial cells in all ten endometrial samples. All glandular cells of the endometrium were stained strongly with monoclonal antibody against P-cadherin irrespective of their localization in the epithelial. lining. Strong granular staining was observed at cell-to-cell boundaries. (Fig. 1A) No gland-to-gland variation in staining intensity was noted. Stromal components from endometrium did not show staining for P-cadherin. In the adjacent serial sections identical glandular structures revealed positive staining for $\mathrm{E}$-cadherin. All endometriotic lesions showed positive staining for $\mathrm{P}-\mathrm{cadherin}$ in the glandular structures that were present (Fig. 1B). In 2 cases no clear glandular structures were recognized. In these two cases the stromal components did not stain for P-cadherin. The staining characteristics for the monoclonal antibody against E-cadherin were comparable to those for P-cadherin.

\section{Discussion}

To our knowledge this is the first report which describes the expression of P-cadherin in human endometrium. P-cadherin was detected in normal human endometrium and endometriotic lesions during the early follicular phase of the menstrual cycle.

The P-cadherin expression pattern was similar to that of E-cadherin. The staining characteristics found in the present study for E-cadherin in endometrium were in accordance with results of other reports $(2,3)$. Expression of E-cadherin was found to be confined to the cell boundaries. It is detected in the endometrial epithelium as well as in almost all other epithelia and is considered to be the main subclass of cadherin, responsible for intercellular adhesion (2). Shimoyama and coworkers (5) detected P-cadherin in the basal or parabasal layers but not in the upper layers in the stratified epithelia that were tested which suggests a close relationship with differentiation. A functional role of E-cadherin in the adhesion of retrogradely shed endometrial tissue to the peritoneal lining was considered less likely, because of the low expression of E-cadherin in the human peritoneum (3). P-cadherin as well as E-cadherin might both play a role in the maintenance of epithelial structures in endometrium and endometriosis. Shimoyama and coworkers (4) found that P-and E-cadherin had a tissue distribution distinct from each other, but the basal or lower layers of stratified or pseudostratified epithelia expressed both molecules. P-cadherin was absent in upper layers of stratified squamous epithelium and in normal glandular epithelium, such as the glandular epithelium of the prostate. They suggested that P-cadherin could be correlated with the maintenance of the proliferative compartment of certain epithelia. The present study suggests that $\mathrm{P}-\mathrm{cadherin}$ may 
also play a role in the maintenance of the proliferative compartment of endometrium. Although it is still unclear what happens between shedding of endometrium into the peritoneal cavity and adhesion to the peritoneal wall, the results of our study suggests that $\mathrm{P}$-cadherin could have a comparable function in endometriotic lesions.

\section{Acknowledgements}

The authors thank Setsuo Hirohashi, M.D. (National Cancer Center Research Institute, Tokyo, Japan) for providing the monoclonal antibody NCC-CAD-299 against human P-cadherin. 


\section{References}

1. Takeichi $\mathbf{M}$. The cadherins: cell - cell adhesion moleculles controlling animal morphogenesis. Development 1988; 102: 639-655.

2. Inoue M, Ogawa H, Miyata M, Shiozaki H, Tanizawa O. Expression of E-cadherin in normal, benign, and malignant tissues of female genital organs. Am J Clin Pathol 1992; 98: 76-80.

3. van der Linden PJQ, de Goeij AFPM, Dunselman GAJ, van der Linden EPM, Ramaekers FCS, Evers JLH. Expression of integrins and E-cadherin in cells from menstrual effluent, endometrium, peritoneal fluid, peritoneum and endometriosis. Fertil Steril 1994; 61: 85-90.

4. Shimoyama $X$, Hirohashi S, Hirano S, Noguchi M, Shimosato Y, Takeichi M, Abe O. Cadherin cell-adhesion molecules in human epithelial tissues and carcinomas. Cancer Res 1991; 51: 2185-2191.

5. Shimoyama Y, Yoshida T, Terada M, Shimosato $\mathbf{Y}$, Abe O, Hirohashi S. Molecular cloning of a human $\mathrm{Ca}^{2+}$ dependent cell-cell adhesion molecule homologues to mouse placentall cadherin: its low expression in human placental tissues. J Cell Biol 1989; 109: 1787-1794. 



\section{Chapter 6}

\section{Expression of cadherins and}

integrins in human endometrium throughout the menstrual cycle

P.J.Q. van der Linden, A.F.P.M. de Goeij, G.A.J. Dunselman, H.W.H. Erkens and J.L.H. Evers 


\section{Abstract}

Objective: To detect cadherin and integrin expression in biopsies of endometrium in the phases of the cycle. Cell adhesion molecules may be involved in endometrial shedding during menstruation and attachment of shed endometrial tissue to the peritoneal lining in endometriosis patients.

Design: An immunohistochemical study on fresh frozen sections.

Setting: Tertiary-care university medical center.

Patients: Sixteen patients undergoing monitoring of their cycle as part of a subfertility work- up. All patients had regular and ovulatory cycles.

Interventions: Endometrium samples were obtained at well-defined phases of the cycle. Simultaneously, blood samples were collected for estradiol and progesterone assay.

Main Outcome Measures: The expression of cell adhesion molecules, including $E$ - and P-cadherin and the integrins $\alpha 2 \beta 1, \alpha 3 \beta 1, \alpha 4 \beta 1, \alpha 5 \beta 1$ and $\alpha 6 \beta 1$, and the expression of estrogen receptor and progesterone receptor.

Results: E- and P-cadherin expression was demonstrated in all endometrium samples. Integrins $\alpha 3 \beta 1, \alpha 4 \beta 1, \alpha 5 \beta 1$, and $\alpha 6 \beta 1$ were detected in samples from all cycle phases, whereas integrin $\alpha 2 \beta 1$ was not detected in midluteal samples. The serum levels of $E_{2}$ were $24.7 \mathrm{pg} / \mathrm{mL}$ (range: 10.9 to $35.4 \mathrm{pg} / \mathrm{mL}$ ) in the early follicular phase and $190.7 \mathrm{pg} / \mathrm{mL}$ (range: 152.5 to $256.1 \mathrm{pg} / \mathrm{mL}$ ) in the preovulatory phase (conversionfactor to SI unit, 3.671). Serum progesterone was $13.7 \mathrm{ng} / \mathrm{mL}$ (range: 10.3 to $16.7 \mathrm{ng} / \mathrm{mL}$ ) in the midluteal phase and $6.4 \mathrm{ng} / \mathrm{mL}$ (range: $1.2-13.7 \mathrm{ng} / \mathrm{mL}$ ) in the premenstrual phase (conversionfactor to SI unit, 3.180). The portion of cells staining for estrogen receptor and progesterone receptor was at a maximum during the preovulatory phase, both for epithelial and stromal cells.

Conclusions: E- and P-cadherin expression was detected in all samples and did not vary throughout the menstrual cycle. If their expression is functionally involved in the cyclic menstrual shedding, the loss of expression is limited to a short period of time. Of the $\beta 1$ integrins, only $\alpha 2 \beta 1$ expression was modulated during the menstrual cycle and found to be absent in the midluteal phase. No relation was found between the expression of cell adhesion molecules and the expression of estrogen receptor and progestrone receptor. Since the cadherins and $\beta /$ integrins could be detected in late luteal phase endometrium, these cell adhesion molecules could be involved in the attachment of endometrial fragments to the peritoneal lining as a result of retrograde menstruation. The potential function in the pathogenesis of endometriosis remains to be elucidated. 


\section{Introduction}

In the development of endometriosis, retrograde transport of viable endometrium fragments and attachment to peritoneum is considered essential, according to Sampson's classical implantation theory (1). Glandular epithelium and stroma of the human endometrium undergo a monthly cycle of first proliferative, and then secretory activity. Breakdown and tissue shedding ensues in the absence of embryo implantation. These changes are driven primarily by two ovarian steroid hormones, estrogen and progesterone, mediated by their respective receptors, which are expressed in epithelial and stromal cells. The presence of viable endometrial tissue fragments in peritoneal fluid has been demonstrated during the early follicular phase of the cycle in women with patent tubes (2). Cell adhesion molecules, such as cadherins and integrins, could be functionally involved in the shedding of endometrium during menses and in the adhesion of endometrial cells to the peritoneum $(3,4)$. Therefore, it is of interest to detect the expression of these cell adhesion molecules in endometrium.

Cadherins belong to a group of calcium-dependent transmembrane glycoproteins that mediate adhesion between cells which express the same cadherin (homophylic cell-cell interaction) (5). Cadherins are responsible for cytoskeletal organization as important constituents of adherens junctions. Cadherins play an important role in invasive processes and metastasis of tumor cells (6-10). Three types of cadherins have been described, E-, P-, and N-cadherin. Each has a characteristic tissue distribution and their expression varies during different stages of development. E-cadherin (also known as Arc-1, uvomorulin, and cell-CAM 120/80) is expressed in all proliferating epithelial cells derived from the ectoderm and the entoderm. Neural and mesodermal tissues do not express E-cadherin, with the exception of some components of the urogenital system and some mesothelial layers (5). E- and P-cadherin expression has been demonstrated in the cell-to-cell boundaries of the endometrium during the early follicular phase of the cycle in human endometrium samples $(3,4)$. The expression of E-cadherin was decreased moderately in samples from menstrual effluent and it was decreased severely in epithelial cells obtained from peritoneal fluid as compared with endometrial tissue. In the human, endometrial architecture and function are influenced strongly, both directly and indirectly, by estrogens and progesterone. The functional and the basal layer of the human endometrium show distinct physiologic functions and responses to hormonal stimuli. Experiments in rats have shown the expression of E-cadherin of granulosa cells to be stimulated by estradiol (10). No reports on the expression of E-cadherin and P-cadherin during the menstrual cycle have been published yet, whereas cyclic expression of integrins, which belong to another family of cell adhesion molecules, has been studied (11). Integrins bind to various extracellular matrix components and mediate cell-matrix interactions during cell 
adhesion and cell migration. The integrins of the $\beta 1$ family serve as receptors for various extracellular matrix proteins. The integrins $\alpha 2 \beta 1, \alpha 3 \beta 1, \alpha 4 \beta 1, \alpha 5 \beta 1$ and $\alpha 6 \beta 1$ are present in endometrium during the early follicular phase of the cycle (3).

The aim of the present study was to detect cadherin and integrin expression in human endometrium during various phases of the cycle. To this end, E- and P-cadherin expression and the expression of the integrins $\alpha 2 \beta 1, \alpha 3 \beta 1, \alpha 4 \beta 1$, $\alpha 5 \beta 1$ and $\alpha 6 \beta 1$ in human endometrium was studied prospectively in biopsies obtained at different, well-defined phases of the menstrual cycle, using immunohistochemistry. The expression was correlated to serum levels of estradiol$17 \beta$ and progesterone and to the expression of estrogen receptor and progesterone receptor in endometrium samples.

\section{Materials and methods}

Endometrium samples at four well-defined phases of the menstrual cycle were obtained from 16 patients: early follicular (cycledays 2 to 5), preovulatory, midluteal (ovulation +7 days) and immediately before the expected menstruation (menstruation -1 to 3 days). The institutional research board and the medical ethics commitee approved the study protocol and all patients gave informed consent. To prevent disturbance of the endometrium by previous sampling, only one sample was obtained during each menstrual cycle from each individual patient. The menstrual cycle was monitored using ultrasound and bloodsampling of estradiol and progesterone during the respective phases of the cycle. All women had a regular and ovulatory cycle, as demonstrated by ultrasound and an adequate rise in serum progesterone in the luteal phase of the cycle. The mean serum estradiol concentrations were $24.7 \mathrm{pg} / \mathrm{mL}$ (range: 10.9 to $35.4 \mathrm{pg} / \mathrm{mL}$ ) during the early follicular phase and $190.7 \mathrm{pg} / \mathrm{mL}$ (range: 152.5 to $256.1 \mathrm{pg} / \mathrm{mL}$ ) during the preovulatory phase of the cycle (conversionfactor to SI unit, 3.671). The mean serum progesterone concentrations were $13.7 \mathrm{ng} / \mathrm{mL}$ (range 10.3 to $16.7 \mathrm{ng} / \mathrm{mL}$ ) during the midluteal phase and $6.4 \mathrm{ng} / \mathrm{mL}$ (range: 1.2 to 13.7 $\mathrm{ng} / \mathrm{mL}$ ) during the premenstrual phase of the cycle (conversionfactor to SI unit, 3.180). Endometrium samples were obtained by using a Probet endometrial sampling device (Gynetics, Oisterwijk, The Netherlands). The samples of endometrium were frozen in isopentane, immersed in dry ice. All samples were stored at $-70^{\circ} \mathrm{C}$ until analyzed.

Cryostat sections of $6 \mu \mathrm{m}$ thickness were prepared and mounted on slides. The sections were air-dried and fixed with methanol at $-20^{\circ} \mathrm{C}$ for 1 minute, followed by an acetone dip at $-20^{\circ} \mathrm{C}$, when used for staining with antibodies against cadherins and integrins. Slides were washed three times for 5 minutes in 
phosphate-buffered saline (PBS), and immersed in $0.3 \%$ hydrogen peroxide to block endogenous peroxidase activity. The sections were washed again three times for 5 minutes in PBS and then preincubated with diluted normal sheep serum (1:5) for 15 minutes. A series of mouse monoclonal antibodies was used including HECD-1 for E-cadherin (R\&D Systems Europe, Abingdon, United Kingdom), NCC-CAD-299 for P-cadherin, IOG11 for integrin $\alpha 2 \beta 1$, J143 for $\alpha 3 \beta 1, \mathrm{HP} 2 / 1$ for integrin $\alpha 4 \beta 1$ and SAM-1 for $\alpha 5 \beta 1$, respectively. Also the rat monoclonal antibody $\mathrm{G} 0 \mathrm{H} 3$ for $\alpha 6 \beta 1$ was applied. Incubation with primary antibodies against integrins and cadherins was performed in appropriate dilutions for 1 hour at $37^{\circ} \mathrm{C}$. After washing three times for 10 minutes in PBS, the sections with the mouse monoclonal antibodies were incubated for 30 minutes with biotin-labeled sheep anti-mouse immunoglobulin (Ig) G (Amersham Nederland B.V., Den Bosch, The Netherlands). After washing in PBS, the sections were incubated with a streptavidin-biotin-peroxidase complex (Dako A/S, Glostrup, Denmark) for 30 minutes. To stain the rat monoclonal antibody $\mathrm{GOH} 3$ the slides were washed three times for 10 minutes and then incubated for 60 minutes with rabbit anti-rat IgG conjugated with horseradish peroxidase (Dako A/S, Glostrup, Denmark). Antibody binding was visualized using 3'-3diaminobenzidine and hydrogen peroxide. The slides were counterstained with hematoxylin. For detection of estrogen receptor or progesterone receptor, sections were fixed with Zamboni fluid (picric acid and paraformaldehyde) for 10 minutes (12). The sections were then washed three times for 5 minutes in PBS and then preincubated with diluted normal sheep serum (1:5) for 15 minutes. The mouse monoclonal antibody NCL-ER-LH1 for estrogen receptor and NCLPGR for progesterone receptor (Novocastra Laboratories Ltd., Newcastle upon Tyne, United Kingdom) were applied. Incubation with primary antibodies against estrogen receptor and progesterone receptor was done in appropriate dilutions for 16 hours at $4^{\circ} \mathrm{C}$. Sections were stained using a streptavidin-biotin complex method and counterstained with methyl green $1 \%$. Stained slides were dehydrated through alcohols, cleared in xylene, and mounted in Entellan for light microscopy. Positive staining for the cell adhesion molecules was defined as immunoreactivity at the periphery of the cells and for the hormone receptors as specific nuclear staining. Negative controls included sections stained without the primary antibody, using PBS instead. For E- and P-cadherin and integrins positive controls consisted of known positive samples of colon and endometrium. For $\mathrm{P}$-cadherin also bronchial epithelium was used as positive control. For estrogen receptor and progesterone receptor positive controls consisted of endometrium and breast tissue. The localization and distribution of specific staining of estrogen receptor and progesterone receptor was evaluated visually in 10 separate cohorts of 100 cells in each individual sample. The percentage of 
intact convincingly classified as epithelial or stromal positively stained cells was evaluated.

\section{Results}

From each of 16 patients one endometrium sample was collected. Four samples from each of the four phases of the menstrual cycle were obtained. The results of the immunohistochemical staining with the anti-E- and anti-P-cadherin monoclonal antibodies are summarized in table $1 . \mathrm{E}$ - and $\mathrm{P}$-cadherin expression was revealed in endometrium samples from all cycle phases. All glandular cells of the endometrium stained strongly for both E- and P-cadherins. No gland-togland variation was noted. Stromal components did not show staining for either cadherin. Table 2 summarizes the results of the immunohistochemical staining with the various monoclonal antibodies against integrins in the endometrium samples. The integrins $\alpha 3 \beta 1, \alpha 4 \beta 1, \alpha 5 \beta 1$ and $\alpha 6 \beta 1$ were detected in endometrium tissue from all phases of the menstrual cycle. No differences were noted in staining intensity or proportion in the various specimens. None of the samples from the midluteal phase of the cycle stained for $\alpha 2 \beta 1$, whereas in the other phases of the cycle staining for $\alpha 2 \beta 1$ was readily detected except for one preovulatory sample that did not reveal expression of $\alpha 2 \beta 1$. Integrin $\alpha 4 \beta 1$ expression showed a gland-to-gland variation. The expression of $\alpha 6 \beta 1$ was confined to the basolateral surface of the epithelial cells. Integrin $\alpha 5 \beta 1$ was not found in the epithelium, but was detected in the stromal cells of the endometrium. Figure $\mathbb{1}$ illustrates representative staining patterns of some of the monoclonal antibodies against cadherins and integrins.

The serum concentration of estradiol during the follicular phase and of progestrone during the secretory phase respectively confirmed the respective phase of the cycle. Figure 2 illustrates the percentage of positive immunohistochemical staining of estrogen receptor and progesterone receptor in epithelial and stromal cells of the endometrium during the respective cycle phases. Expression of estrogen receptor reached a maximum during the preovulatory phase in both epithelial and stromal cells of the endometrium. In the luteal phase, estrogen receptor staining strongly decreased in both cell types. Progesterone receptor also reached preovulatory a maximum. During the midluteal and premenstrual phase of the cycle stromal cells stained moderately for progestrone receptor, in contrast to epithelial cells, which only showed minimal staining. All negative controls did not show any positive staining. 


\section{Table 1}

E- and P-cadherin expression in endometrium from 16 women on different phases of the menstrual cycle

Monoclonal antibody/antigen

$\begin{array}{lll} & \text { HECD-1 } & \text { NCC-CAD-299 } \\ \text { cycle phase } & \text { E-cadherin } & \text { P-cadherin }\end{array}$

$\begin{array}{lll}\text { early follicular } & 4 / 4 & 4 / 4 \\ \text { preovulatory } & 4 / 4 & 4 / 4 \\ \text { midluteal } & 4 / 4 & 4 / 4 \\ \text { premenstrual } & 4 / 4 & 4 / 4\end{array}$

Number of cases with positive staining over number of cases

\section{Table 2}

Integrin expression in endometrium from 16 women on different phases of the menstrual cycle

\begin{tabular}{|c|c|c|c|c|c|}
\hline \multirow[b]{2}{*}{ cycle phase } & \multicolumn{5}{|c|}{ Monoclonal antibody/antigen } \\
\hline & $\begin{array}{l}10 \mathrm{G} 11 \\
\alpha 2 \beta 1\end{array}$ & $\begin{array}{l}J 143 \\
\alpha 3 \beta 1\end{array}$ & $\begin{array}{l}\mathrm{HP} 2 / 1 \\
\alpha 4 \beta 1\end{array}$ & $\begin{array}{l}\text { SAM1 } \\
\alpha 5 \beta 1\end{array}$ & $\begin{array}{l}\text { GOH3 } \\
\alpha 6 \beta 1\end{array}$ \\
\hline early follicular & $4 / 4$ & $4 / 4$ & $4 / 4$ & $4 / 4$ & $4 / 4$ \\
\hline preovulatory & $3 / 4$ & $4 / 4$ & $4 / 4$ & $4 / 4$ & $4 / 4$ \\
\hline midluteal & $0 / 4$ & $4 / 4$ & $4 / 4$ & $4 / 4$ & $4 / 4$ \\
\hline premenstrual & $4 / 4$ & $4 / 4$ & $4 / 4$ & $4 / 4$ & $4 / 4$ \\
\hline
\end{tabular}

Number of cases with positive staining over number of cases 

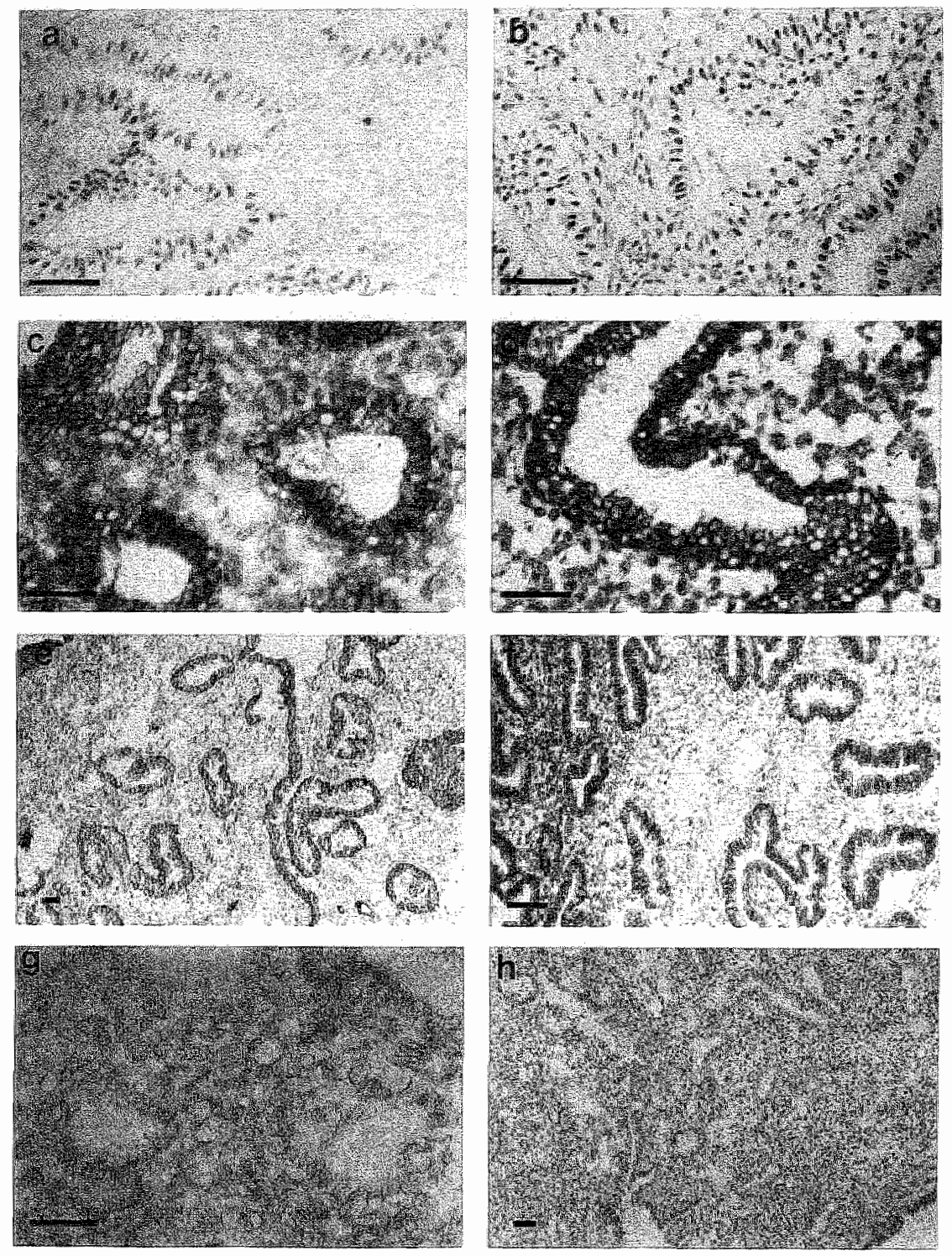

\section{Figure 1}

Staining patterns of various samples of endometrium after incubation with $\mathrm{mAbs}$.

(A), Early follicular endometrium stained for estrogen receptor with NCL-ER-LHL. (B), Early follicular endometrium stained for progesterone receptor with NCL-PGR. (C), Midluteal endometrium stained for E-cadherin with HECD-1. (D), Premenstrual endometrium stained for P-Cadherin with NCC-CAD-299. (E). Midluteal endometrium stained for integrin $\alpha 3 \beta 1$ with J143. (F), Preovulatory endometrium stained for $\alpha 4 \beta 1$ with HP2/1. (G), Negative control of midluteal endometrium of $1 \mathrm{C}$. $(\mathbf{H})$ Negative control of midluteal endometrium of IE. Bar indicates $55 \mu \mathrm{m}$. 


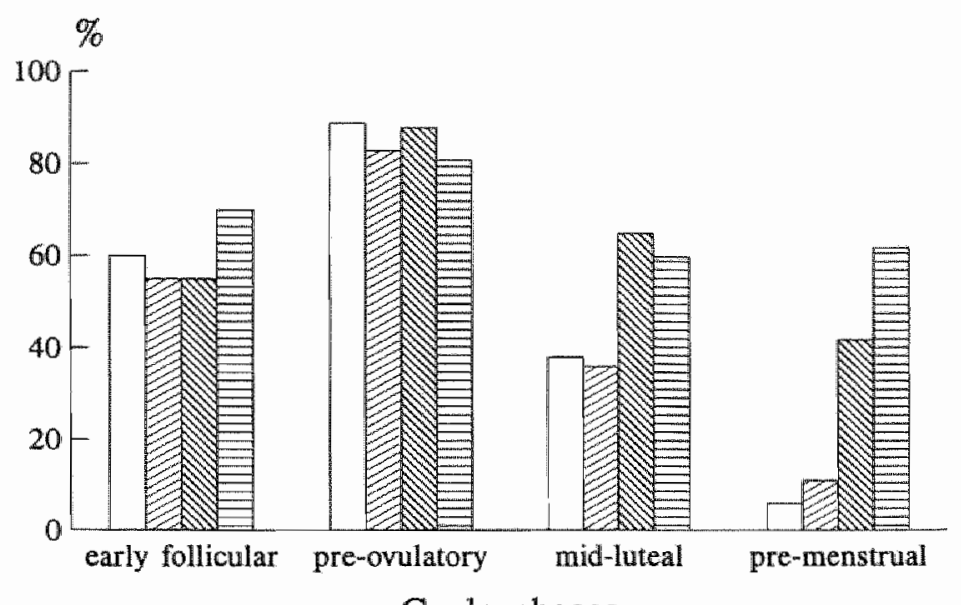

Cycle phases

$\square$ ER, epithelial $\oslash \mathrm{ER}$, stromal $\mathrm{PR}$, epithelial $\oslash \mathrm{PR}$, stromal

Figure 2

Percentage of cells with positive immunohistochemical staining of estrogen receptor (ER) and progesterone receptor (PR) in endometrial epithelium and stroma during four phases of the cycle.

\section{Discussion}

During the menstrual cycle the endometrium develops into a well-differentiated tissue susceptible to implantation of the human embryo. The ensuing bleeding and tissue breakdown results in subsequent retrograde reflux of viable endometrial cells. Adhesion of these cells to peritoneum may result ultimately in the development of endometriosis. Normal endometrium shows temporal variations in morphology and function throughout the menstrual cycle. E-cadherin is expressed at the boundaries of all normal epithelial cells in the human female genital tract. Only recently the presence of P-cadherin in human endometrium has been reported (4). E- and P-cadherin expression in endometrium is detected on the lateral cell surfaces and in intercellular junctions known as the zonulae adherentes. In the present study, E- and P-cadherin expression was found in all phases of the cycle in the glandular epithelium. Expression and function of cell adhesion molecules may be under hormonal control. There was no correlation of the E- and P-cadherin expression with the serum concentrations of estradiol or progesterone. In rat experiments, the expression of cadherin by ovarian granulosa cells was found to be enhanced by estradiol in vitro (10). However, 
differences have been found in the expression of cell adhesion molecules between some animal and human tissues, which may render animal experiments less relevant for the study of cell adhesion. For example, whereas P-cadherin was identified in the mouse placenta, it cannot be detected in the human placenta (13). Also human ovarian tissues do not express E-cadherin, except for germinal epithelium (5). In human endometrium, estradiol and progesterone do not seem to be the regulators of cadherin expression. This is in line with the observation that the expression is not correlated to the expression of estrogen receptor and progesterone receptor as determined by immunohistochemistry. The expression patterns that were found for estrogen receptor and progesterone receptor were similar to those reported previously from our group by Snijders and co-workers (12).

In a study of Inoue and co-workers (6), glandular cells of the cervix, endometrium, and fallopian tube showed strong expression of E-cadherin. In the cervix and the vagina the staining reactivity decreased with maturation of the normal squamous epithelium. Superficial cells that likely were to be exfoliated were negative. In our study the endometrium samples from the premenstrual phase of the cycle did also show expression of E- and P-cadherin. This suggests that $\mathrm{E}$ - and P-cadherin are not involved functionally in the cyclic menstrual shedding process. Alternatively, the expression may not be lost on the endometrial cells that remain in situ and hence are found in the biopsies, but only endometrial cells that are shed in the menstrual effluent loose their cadherin expression. However, in a previous study, we have found E-cadherin expression on these cells (3). Another possibility could be that the loss of expression occurs but is limited to a very short period of time between the premenstrual and early follicular phase of the cycle. This would represent the time of onset of the actual menstruation. Inoue and co-workers (6) found the presence of E-cadherin expression in metastatic lesions to be similar to that in their primary tumors and this seemed incompatible with a role of cell adhesion molecules in tumor metastasis. They also found that poorly differentiated malignant tumor cells often have lost their E-cadherin expression. The loss of these cell adhesion molecules would than be one factor in the release of these cells from their primary site. This process is probably not comparable with the physiologic process leading to shedding of normal endometrium during menses.

The integrins $\alpha 3 \beta 1, \alpha 4 \beta 1, \alpha 5 \beta 1$, and $\alpha 6 \beta 1$ were detected in endometrium samples from all phases of the cycle. The staining characteristics were comparable with those reported earlier (3). The absence of integrin $\alpha 2 \beta 1$ in the midluteal samples is in contrast with another study where a uniform expression throughout the cycle for $\alpha 2, \alpha 3$ and $\alpha 5$ subunits was reported (14). The finding of $\alpha 4 \beta 1$ in all samples also was in contrast with results from studies by Lessey and co-workers (14), who could not detect expression of $\alpha 4 \beta 1$ in any phase of 
the cycle. Tabibzadeh (11) could detect $\alpha 4 \beta 1$ only in endometrium from the midproliferative and midsecretory phase, whereas $\alpha 2 \beta 1$ was found in all phases of the cycle. He suggested a correlation between the expression of integrins and the level of circulating steroids. In our study the expression of $\alpha 2 \beta 1$ was absent during the midluteal phase, when progesterone levels were highest. But if only the level of progesterone is important, then one would expect $\alpha 2 \beta 1$ to be absent premenstrually, when progesterone levels can still be relatively high (Fig. 2). Hence, the combination of a certain decline in estradiol and a rise in progesterone could be the prerequisite for $\alpha 2 \beta 1$ expression to appear. A similar process has been suggested for $\beta 3$ integrin, which appears on day 20 of the cycle (14).

In conclusion, the present study shows that, except integrin $\alpha 2 \beta 1$, the expression of all cell adhesion molecules studied is not dependent on the phase of the cycle. This indicates a minor role for estradiol and progesterone in the regulation of cell adhesion molecules. However, this study is not conclusive with respect to functional involvement of these cell adhesion molecules. If loss of E- and P-cadherin is involved functionally in the process of cyclic menstrual shedding, this has to be limited to a very short period of time. E- and P-cadherin may play a role in the maintenance of epithelial architecture in the endometrium, not only during the proliferative phase but also during the secretory phase of the cycle. Expression of integrins in the endometrium can be important for embryo implantation, as has been suggested by Lessey and co-workers (14). Although all cell adhesion mollecules were expressed in late luteal phase endometrium, their role in attachment of endometrial fragments to the peritoneal lining remains to be elucidated. This would require a fine tuning of the sampling of the endometrium both in time and in space. Future research preferably should be done in in vitro experiments because of the restrictions of repeated measurements in humans and because of the differences between several animal species and the human in their expression of cell adhesion molecules.

\section{Acknowledgements}

The authors thank Setsuo Hirohashi, M.D. (National Cancer Center Research Institute, Tokyo, Japan) for providing the monoclonal antibody NCC-CAD-299 against human P-cadherin, Arnoud Sonnenberg, Ph.D. (Central Laboratory of The Netherlands Red Cross Transfusion Service, Amsterdam, The Netherlands) for providing the monoclonal antibodies I0G1 $1, J 143$ and GOH3 and Carl Figdor, Ph.D. (The Netherlands Cancer Institute, Amsterdam, The Netherlands) for providing the monoclonal antibodies HP2/1 and SAM-1. We are indebted to Mrs. Edith P.M. van der Linden for her expert technical advises. 


\section{References}

1. Haney AF. The pathogenesis and aetiology of endonetriosis. In: Thomas EJ, Rock JA, editors. Modern approaches to endometriosis. Dordrecht, Boston, London: Kluwer Academic Publisher, 1991; 3-19.

2. Kruitwagen RFPM, Poels LG, Willemsen WNP, de Ronde IIY, Iap PHK, Rolland R. Endometrial epithelial cells in peritoneal fluid during the early follicular phase. Fertil Steril 1991; 55: 297-303.

3. van der Linden PIQ, de Goeij AFPM, Dunselman GAJ, van der Linden EPM, Ramaekers FCS, Evers JLH. Expression of integrins and E-cadherin in cells from menstrual effuent, endometrium, peritoneal fluid, peritoneum and endometriosis. Fertil Steril 1994; 61:85-90

4. van der Linden PJQ, de Goeij AFPM, Dunselman GAJ, Arends JW, Evers JLH. Pucadherin expression in human endometrium and endometriosis. Gynaecol Obstet Invest 1994; 38: 183-185

5. Takeichi M. The cadherins: cell - cell adhesion molecules controlling animal morphogenesis. Development 1988; 102: 639-655.

6. Inoue $\mathbf{M}$, Ogawa $\mathbf{H}$, Miyata $\mathbf{M}$, Shiozaki $\mathbf{H}$, Tanizawa 0 . Expression of E-cadherin in normal, benign, and malignant tissues of female genital organs. Am $J$ Clin Pathol 1992; 98: 76-80.

7. Frixen UH, Behrens J, Sachs $\mathbf{M}$, Eberle G, Voss B, Warda A, Löchner D, Birchmeier W. E-Cadherin mediated cell-cell adhesion prevents invasiveness of human carcinoma cells. J Cell Biol 1991; 113: 173-185.

8. Vlemminckx K, Vakaet L, Mareel M, Fiers W, van Roy F. Genetic manipulation of E-Cadherin expression by epithelial turnor cells reveals an invasion suppressor role. Cell 1991; 66:107-119.

9. Hashimoto M, Niwa O, Nitta $\mathbf{Y}$, Takeichi M, Yokoro K. Unstable expression of E-Cadherin adhesion molecules in metastatic ovarian tumor cells. Jpn J Cancer Res 1989; 80: 459-463.

10. Blaschuk OW, Farookhi R. Estradiol stimulates cadherin expression in rat granulosa cells. Dev Biol 1989; 136: 564-567.

11. Tabibzadeh S. Patterns of expression of integrin molecules in human endometrium throughout the menstrual cycle. Hum Reprod 1992; 7: 876-882.

12. Snijders MPML, de Goeij AFPM, Debets-TeBaert MJC, Rousch MJM, Koudstaal J, Bosman FT. Immunocytochemical analysis of oestrogen receptors and progesterone receptors in the human uterus throughout the menstrual cycle and after the menopause. J Reprod Fert 1992; 94: 363-371.

13. Shïmoyama $\mathbf{Y}$, Hirohashi S, Hirano S, Noguchi M, Shimosato Y, Takeichi M, Abe O. Cadherin cell-adhesion molecules in human epithelial tissues and carcinomas. Cancer Res 1991; 51: 2185-2191.

14. Lessey BA, Danjanovich L, Coutifaris C, Castelbaum A, Albelda SM, Buck CA. Integrin adhesion molecules in the human endometrium. Correlation with the normal and abnormal menstrual cycle. J Clin Invest 1992; 90: 188-195. 


\section{Chapter 7}

\section{Amniotic membrane as an in vitro model for endometrium-extracellular matrix interactions}

P.J.Q. van der Linden, A.F.P.M. de Goeij, G.A.J. Dunselman, H.W.H. Erkens and J.L.H. Evers 


\section{Abstract}

Objective: To develop an in vitro model to study the interaction between endometrial cells and extracellular matrix (ECM) and to evaluate the expression of cell adhesion molecules in endometrial cells and tissue fragments under in vitro conditions.

Study design: Endometrial biopsies were collected from 32 patients. Samples were either digested using collagenase type 1 , or dissected mechanically. Adhesion of isolated cells and tissue fragments to stripped amniotic membranes and to coverslips coated with ECM components was studied. Also the steroid responsive endometrial carcinoma cell lines RL95-2 and AN3CA were used. The expression of $\beta 1$ integrins and cadherins was assessed using immunohistochemistry.

Results: Collagenase digestion of endometrial biopsies yielded viable single cells. These cells did not adhere to either side of stripped amniotic membranes, and did not show expression of the cell adhesion molecules. In contrast, mechanically fragmented endometrium samples adhered to both sides of stripped amniotic membranes and showed immunohistochemical expression of E- and P-cadherin and integrins $\alpha 2 \beta 1, \alpha 3 \beta 1, \alpha 4 \beta 1, \alpha 5 \beta 1$ and $\alpha 6 \beta 1$. The carcinoma cell lines RL95-2 and AN3CA adhered rapidly to amniotic membranes and to coverslips coated with ECM components. Several cell adhesion molecules could not be demonstrated on the carcinoma cell lines with immunohistochemistry.

Conclusion: Amniotic membranes, after stripping of epithelial lining, are suitable to study interactions between endometrial tissue and extracellular matrix in functional and structural studies. Endometrial cells after collagenase type $I$ digestion do not adhere to stripped amniotic membrane and have lost expression of $\beta 1$ integrins and $\mathrm{E}$ - and $\mathrm{P}$-cadherin. Carcinoma cell lines can serve as an in vitro model for the study of adhesion behavior.

\section{Introduction}

Cell-cell adhesion and its regulation are essential in the physiology and the pathophysiology of the human endometrium, i.e. in menstrual shedding, in embryo adhesion and nidation, trophoblast invasion, endometriosis, and invasive growth of endometrial carcinoma. The endometrial glandular epithelial cells not only have a strong and specific intercellular adherence, but are also tightly connected with the extracellular matrix (ECM). It is largely unknown how this cellular adhesion is regulated, but we assume that cadherins and integrins are involved. In several reports it has been shown that endometrial cells express these cell adhesion molecules $(1,2,3,4)$. An increasing body of evidence 
indicates that stroma is very important in stimulation and inhibition of glandular epithelium $(5,6)$. It is feasible that stromal cells are actively involved in cellular adhesion in endometrium.

Cellular adhesion is considered essential in the pathogenesis of endometriosis $(1,2)$. According to the implantation theory, endometrial tissue fragments and cells are shed into the peritoneal cavity by retrograde menstruation and may develop into endometriosis (7). The process that occurs between retrograde menstruation and the development of endometriosis, and in particular the adthesion of these cells to the peritoneal lining, is still an enigma. Moreover, if endometrial tissue adheres, it is not clear whether epithelial and/or stromal endometrial cells adhere to the peritoneum. The adhesion of endometrial cells may occur through contact with the mesothelial lining of the peritoneum. Alternatively, the cells may adhere directly to one or more extracellular components of the peritoneum, but that would require either passage of endometrial cells through the mesothelium, or the ECM of damaged peritoneum to be exposed.

Several families of adhesion molecules, i.e. cadherins and integrins, may be involved in these processes. Cadherins belong to a group of calcium-dependent transmembrane glycoproteins that mediate adhesion between cells which express the same cadherin (homophylic cell-cell interaction) and are responsible for cytoskeletal organization $(15,16,17,18,19)$. E- and $P$-cadherin expression has been demonstrated at the cell to cell boundaries of the endometrium in normal human endometrium samples, in endometriosis and in cells that are potentially involved in the pathogenesis of endometriosis $(1,2,20)$. Integrins bind to various ECM components and mediate cell-matrix interactions during cell adhesion and migration. The integrins of the $\beta 1$ family serve as receptors for various extracellular matrix proteins. The integrins $\alpha 1 \beta 1, \alpha 2 \beta 1, \alpha 3 \beta 1, \alpha 4 \beta 1, \alpha 5 \beta 1$ and $\alpha 6 \beta 1$ are present in human endometrium $(1,2,21)$. Evidence has been obtained that the expression of some integrins varies with the phase of the menstrual cycle, suggesting hormonal effects, although conflicting reports have been published $(3,4,20)$. From these immunohistochemical studies no information is obtained on the functional role of these adhesion molecules.

In vitro models may help to understand the process of endometrial tissue adhesion to ECM and its regulation. Several approaches are feasible. Endometrial cells or tissue fragments can be cultured on feeder layers of several cell types, or on isolated extracellular matrix components $(8,9,10)$. Many established cell lines or primary cell cultures have been grown on coatings of ECM components such as collagen I, laminin, fibronectin (11). Also mixtures of these components have been used, including Vitrogen 100 (collagen I + III) and Matrigel (Iaminin, type IV collagen, and heparan sulphate proteoglycan) (12). 
Several investigators have used stripped human amniotic membranes as a model for epithelial cell-ECM interactions $(13,14)$.

The aim of the present study was to develop an in vitro model to study the adhesion of endometrial tissue to ECM, and to evaluate the expression of cell adhesion molecules in endometrial cells and tissue fragments potentially involved.

\section{Materials and methods}

\section{Tissues and cells}

Endometrium biopsies were collected from 32 patients using a Probet endometrial sampling device (Gynetics, Oisterwijk, The Netherlands) during a diagnostic laparoscopy, as part of their subfertility work-up. All women had a regular and ovulatory cycle, as demonstrated by ultrasound and an adequate rise of progesterone in the luteal phase of the cycle. The samples were collected during the follicular phase of the cycle. The endometrium biopsies were washed in phosphate-buffered saline (PBS) to remove debris and excess blood cells. The carcinoma cell lines RL 95-2 and AN3CA were obtained from ATCC, Rockville, Maryland, USA.

Fresh human placentas were obtained at the time of normal term delivery. The amnion was separated from chorion and the amniotic basement membrane was stripped from the epithelial lining by chemical and mechanical means as described by Liotta et al.(13). In short, amnion was washed one hour in distilled water and $2 \mathrm{mM} \mathrm{N}$-ethylmaleimide (NEM), extracted during one hour with $1 \mathrm{M}$ $\mathrm{NaCl}, 20 \mathrm{mM}$ EDTA, $2 \mathrm{mM}$ NEM and finally treated with $4 \%$ de-oxycholate for one hour. After each step the membranes were mechanically scraped with a rubber policeman to remove amniotic epithelial cells and most of the interstitial stroma. The stripped membranes were suspended between two metal rings (Fig. 1).

Ten endometrium samples were digested for one hour at $37^{\circ} \mathrm{C}$ with $200 \mathrm{U} / \mathrm{mL}$ type I collagenase (Sigma, St Louis, USA). Five endometrium samples were digested in lower concentrations of collagenase type I, ranging from 20-100 $\mathrm{U} / \mathrm{mL}$. Five endometrium samples were digested using collagenase type I at 1 $\mathrm{U} / \mathrm{mL}$. Cell clumps were dispersed by aspiration through a pasteur pipette.

The viability and number of the collagenase digested cells were determined by counting an aliquot of cells after staining in $0.04 \%$ trypan blue. From five samples also cytological preparations were obtained by cytocentrifugation.

Twelve endometrium samples were gently dissected into small tissue fragments by using scalpels. 
Culture medium

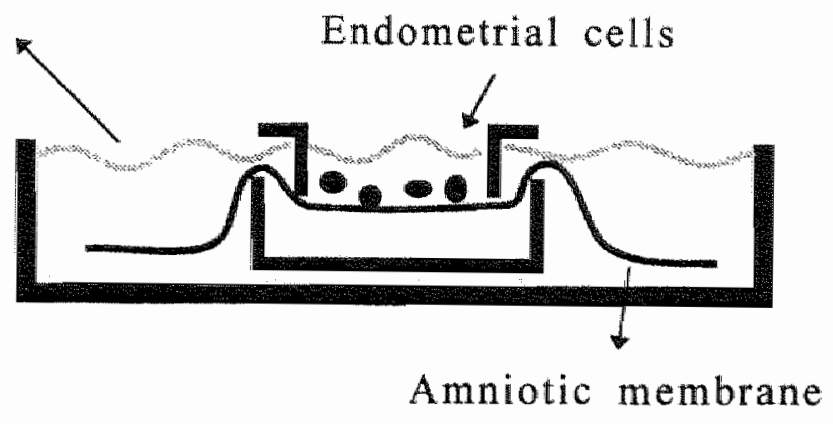

Figure 1

Stripped amniotic membrane (13) suspended between two metal rings

\section{Cell culture}

The cells or tissue fragments were layered on the stripped amniotic membrane and cultured for 24 hours at $37^{\circ} \mathrm{C}$ in DMEM/F-12 medium which consists of equal parts of Dulbecco's Modified Eagle's minimal essential medium(DMEM, Flow Laboratories, Zwanenburg, The Netherlands) and HAM F-12 (Flow Laboratories, Zwanenburg, The Netherlands): The medium was supplemented with 5 10\% charcoal stripped fetal calf serum (FCS, Boehringer, Mannheim, Germany) and with $100 \mathrm{U} / \mathrm{mL}$ penicillin, $100 \mu \mathrm{g} / \mathrm{mL}$ streptomycin and 2.5 $\mu \mathrm{g} / \mathrm{mL}$ amphotericin $\mathrm{B}$. When using collagenase digested cells, 25,000-50,000 cells were layered per suspended amniotic membrane preparation. The carcinoma cell lines were cultured in DMEM/F-12 and 5\% FCS and MEM with $1 \%$ non essential amino acids, $1 \%$ pyruvate and $1 \%$ L-glutamate for RL 95-2 and AN3CA respectively, without antibiotics, as recommended by ATCC. The carcinoma cell lines were layered on amniotic membrane and on glass cover slips coated with collagen type $\mathbb{I}$ and cultured for 24 hours. Furthermore we prepared cytospins of both cell lines. From the cell samples that were treated with collagenase type I digestion, 8 were also layered on glass that was coated with collagen type I, collagen type IV, laminin, Matrigel (Collaborative Research, Bedford, Mass, USA) or Vitrogen 100 (Collagen Corporation, Palo Alto, CA, USA) and then cultured for 24 hours. The amniotic membrane cultures were snap frozen in isopentane embedded in dry ice. All samples were stored at $-70^{\circ} \mathrm{C}$ until analyzed. 


\section{Immunohistochemistry}

Cryostat sections of $6 \mu \mathrm{m}$ thickness were prepared and mounted on slides. The sections were air-dried and fixed with methanol at $-20^{\circ} \mathrm{C}$ for one minute, followed by an acetone dip at $-20^{\circ} \mathrm{C}$. Slides were washed three times for 5 minutes in phosphate-buffered saline (PBS), and immersed in $0.3 \%$ hydrogen peroxide to block endogenous peroxidase activity. The sections were washed again three times for 5 minutes in PBS and then preincubated with diluted normal sheep serum (1:5) for 15 minutes. A series of mouse monoclonal antibodies was used including HECD-1 for E-cadherin (R\&D Systems Europe, Abingdon, Great Britain), NCC-CAD-299 for P-cadherin, I0G11 for integrin $\alpha 2 \beta 1, J 143$ for $\alpha 3 \beta \downarrow, H P 2 / 1$ for integrin $\alpha 4 \beta 1$ and SAM- 1 for $\alpha 5 \beta 1$ respectively. Also the rat monoclonal antibody $\mathrm{GOH} 3$ for $\alpha 6 \beta 1$ was applied. Incubation with primary antibodies against integrins and cadherins was performed in appropriate dilutions for 1 hour at $37^{\circ} \mathrm{C}$. After washing three times for 10 minutes in PBS, the sections with the mouse monoclonal antibodies were incubated for 30 minutes with biotin-labeled sheep antimouse immunoglobulin G (IgG) (Amersham Nederland B.V., Den Bosch, The Netherlands). After washing in PBS, the sections were incubated with a streptavidin-biotin-peroxidase complex (Dako A/S, Glostrup, Denmark) for 30 minutes. To stain the rat monoclonal antibody $\mathrm{GOH} 3$ the slides were washed three times for 10 minutes and then incubated for 60 minutes with rabbit anti-rat IgG conjugated with horseradish peroxidase (Dako A/S, Glostrup, Denmark). Antibody binding was visualized using 3'-3diaminobenzidine and hydrogen peroxide. The slides were counterstained with hematoxylin. Stained slides were dehydrated through alcohols, cleared in xylene and mounted in Entellan for light microscopy. Positive staining for the cell adhesion molecules was defined as immunoreactivity at the periphery of the cells. Negative controls included sections stained without the primary antibody, using PBS instead. For E- and P-cadherin and $\beta 1$ integrins positive controls consisted of known positive samples of endometrium. For the study of the morphology hematoxylin-eosine slides were prepared. The cells and tissue fragments that were cultured on cover slips were air dried and then fixed. After fixation the same immunohistochemical staining procedures were followed for the detection of the cell adhesion molecules.

\section{Results}

Treatment of endometrial samples with collagenase type I yielded single cells with a viability of $80-90 \%$ in all collagenase concentrations tested. The endometrial cells isolated after collagenase treatment did not adhere to stripped amniotic membranes after 24 hours of incubation (table 1). No difference was seen when cells were cultured on either side of the stripped amniotic membranes. 
In contrast, the endometrial cells isolated after collagenase digestion adhered to coverslips coated with human collagen type I, collagen type IV, laminin, Matrigel and Vitrogen 100. Cells that were treated with different concentrations of collagenase did not show differences in adhesion behavior. The cytospin preparations of the collagenase digested cells did not show immunohistochemical staining of cell adhesion molecules, whereas cell adhesion molecules could be demonstrated in the remaining clumps of intact tissue after collagenase digestion as is shown in table 2. The expression of the cell adhesion molecules in the clumps was located mainly in the center of the clump. The periphery of the clumps only showed minimal staining or no staining at all as is shown in figure 2.

Endometrium fragments that were not digested with collagenase, but were only dissected mechanically, adhered to stripped amniotic membrane in all cases as is shown in table 1. No difference was noted in adhesion to either side of the stripped amniotic membranes. Both epithelial cells and stromal cells showed

\section{Table 1}

Adhesion of endometrial cells after digestion with collagenase type $I$ and of dissected endometrium fragments to stripped amniotic membrane and to cover slips coated with collagen type I, collagen type IV, laminin, Matrigel and Vitrogen 100.

Tissue

$\begin{array}{lll} & \text { endometrial cells } & \text { endometrial fragments } \\ \text { collagenase } & \text { mechanically } \\ \text { digested } & \text { dissected }\end{array}$

Amniotic membrane

$\begin{array}{ll}- & + \\ n=20 & n=12\end{array}$

collagen type I

collagen type IV

laminin.

Matrigel

Vitrogen 100

$\begin{array}{ll}+ & + \\ + & + \\ + & + \\ + & + \\ + & + \\ n=8 & n=12\end{array}$

Adhesion: $+=$ adhesion is present, $-=$ no adhesion is present 


\section{Table 2}

Immunohistochemistry of $\beta 1$ integrins and cadherins in single endometrial cells digested with collagenase lype I ( $n=5$ ) remaining clumps of cells after collagenase digestion $(n=5)$ and dissected endometrial fragments $(n=5)$ after incubation for 24 hours on amniotic membrane

\section{Tissue}

$\begin{array}{llll} & \text { single cells } & \text { cell clumps } & \text { fragments } \\ & \text { after } & \text { after } & \text { mechanically } \\ \text { MAb/antigen } & \text { collagenase } & \text { collagenase } & \text { dissected } \\ & \text { digestion } & \text { digestion } & \end{array}$

$10 \mathrm{G} 11$

integrin $\alpha 2 \beta 1$

$\mathrm{J} 143$

integrin $\alpha 3 \beta 1$

$\mathrm{HP} 2 / 1$

integrin $\alpha 4 \beta 1$

$-$

$+$

$+$

SAMI

integrin $\alpha 5 \beta 1$

$+2$

$+2$

$\mathrm{GOH} 3$

integrin $\alpha .6 \beta 1$

NCC-CAD-299

P-cadherin

$+\quad+$

HECD- 1

E-cadherin

$++$

Staining: $+=$ staining is present, $-=$ no staining

${ }^{1}$ Expression is located in the center of the clump, ${ }^{2}$ integrin $\alpha 5 \beta 1$ is only detected in stromal cells 


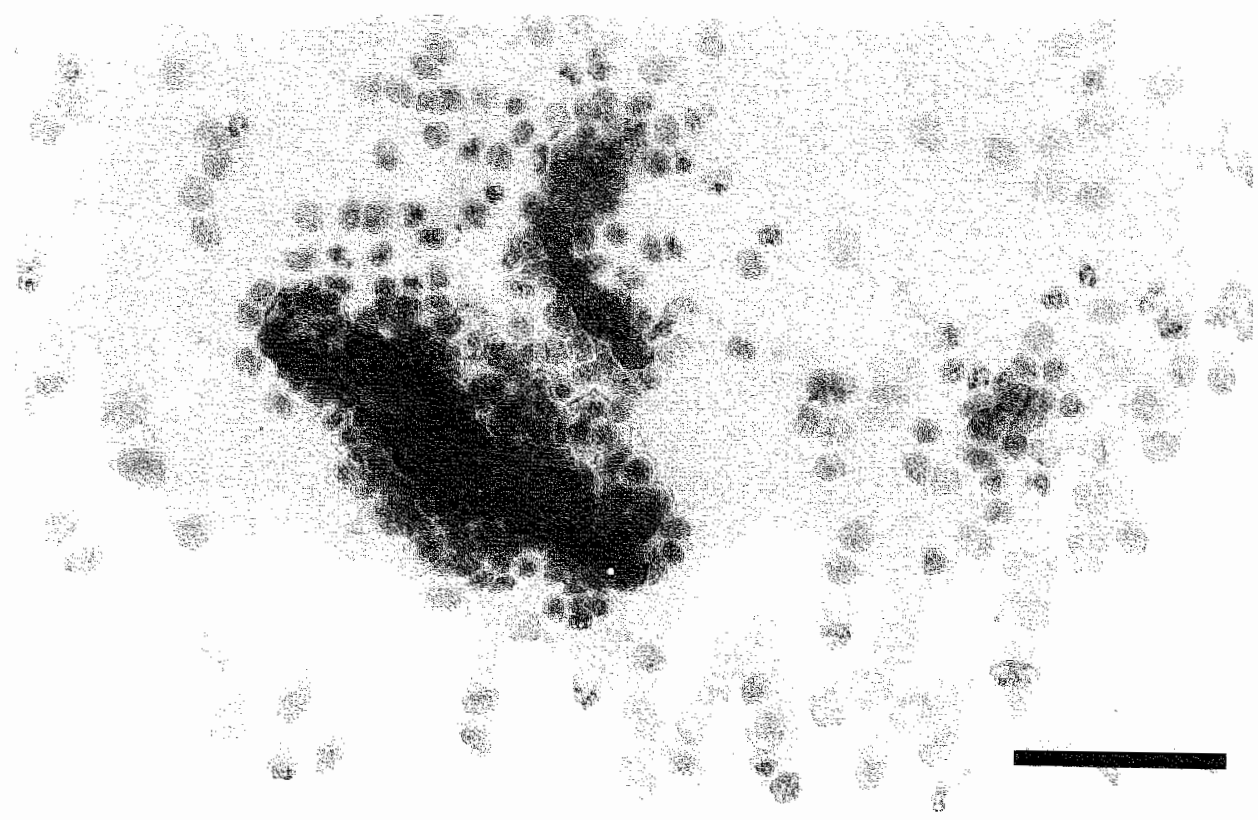

Figure 2

Immunohistochemical staining of an endometrium sample after collagenase type I digestion. Sample stained for integrin $\alpha 3 \beta 1$ with MAb J143. Bar indicates $55 \mu \mathrm{m}$. Cell clumps show expression in the center of the clump. Single cells do not show expression.

adhesion to the stripped amniotic membranes. Table 2 also summarizes the expression of cell adhesion molecules on the dissected endometrium fragments that were cultured for 24 hours on amniotic membranes. Immunohistochemistry showed strong staining for cell adhesion molecules on all these endometrial cells. Epithelial cells of the endometrium fragments showed expression of the integrins $\alpha .2 \beta 1, \alpha 3 \beta 1, \alpha 4 \beta 1$ and $\alpha 6 \beta 1$, whereas $\alpha .5 \beta 1$ was detected only on stromal cells. $\mathrm{E}$ - and P-cadherin was detected on epithelial endometrial cells in all dissected samples.

The endometrium carcinoma cell lines RL 95-2 and AN3CA did grow as monolayers both on coated and uncoated coverslips. When these cells were cultured on stripped amniotic membranes adherence could be observed within a very short time (less than 30 minutes). No difference in adherence was observed on the stripped epithelial side as compared to the stromal face of the amnion. Several cell adhesion molecules could not be detected on these cells, as is shown in table 3. Expression of cell adhesion molecules on the cell lines was similar in cytospin preparations and in frozen sections from cells cultured on amniotic membranes. 


\section{Table 3}

Immunohistochemistry of integrins and cadherins in endometrial carcinoma cell lines RL95-2 and AN3CA

\section{Cell line}

MAb/antigen $\quad$ RL95-2 AN3CA

$10 \mathrm{Gl} 1$

integrin $\alpha 2 \beta 1$

$\int 143$

integrin $\alpha 3 \beta 1$

$+\quad \pm$

$\mathrm{HP} 2 / 1$

integrin $\alpha 4 \beta 1$

SAM

integrin $\alpha 5 \beta 1$

$\mathrm{GOH} 3$

integrin $\alpha .6 \beta 1$

NCC-CAD-299

P-cadherin

HECD-1

E-cadherin

Staining: $+=$ staining is present, $\pm=$ weak staining, $-=$ no staining

\section{Discussion}

Amniotic membrane consists of an extracellular matrix (basement membrane) covered by a single layer of columnar epithelium. The epithelium is attached by hemidesmosomes to the basement membrane, which overlies a loose avascular stroma composed of interstitial collagen and elastin (13). The lamina densa is preserved after stripping procedures. 
The present study shows that amniotic membranes, after stripping of its epithelial lining, are suitable to study interaction between endometrial tissue and extracellular matrix, using biopsy specimens as a tissue source for the endometrium. An additional advantage of this model system is the feature to combine functional studies with structural studies such as immunohistochemistry. Based on the proposed architecture of the amniotic basement membrane (13), the side of the amnion where the epithelium is removed may be a better model for cell-ECM interactions. However, no difference in adhesion to either side of the stripped amnion is noted. Therefore we concluded that both sides of the amnion can be used. The endometrium carcinoma cell lines RL95-2 and AN3CA strongly adhere to both sides of the stripped amniotic membrane. These cells can be used to study adhesion behavior of endometrial carcinoma cells. A disadvantage is that several cell adhesion molecules are not expressed on these cells. This finding is in accordance with results obtained by Thie et al. (22).

Digestion of endometrial tissue with type I collagenase yields suspensions of single endometrial cells of epithelial and stromal origin. The number and viability of these cells can be easily analysed, which is difficult with clumps of tissue. The collagenase digested endometrial cells do not adhere to stripped amniotic membranes, although adhesion to isolated constituents of the basement membrane on glass was observed.

One of the most striking observations was the loss of cell adhesion molecule expression parallelled by loss of adhesion to stripped amniotic membranes of endometrial cells after collagenase digestion. Apparently collagenase destroys both structure and function of cell adhesion molecules at the cellular surface. This suggests a functional role of one or more of these cell adhesion molecules in endometrial cell-ECM interactions. Loss of adherence was not seen with coatings of isolated basement membrane components. We conclude therefore that stripped amniotic membranes serve as a valid model to study interactions between endometrial cells and ECM. Also it is concluded that endometrial cells obtained after collagenase digestion have lost functional cell adhesion molecules and hence are less suitable to study initial phases of adhesion in vitro.

In concordance with the results of the present study it was found earlier that in peritoneal fluid single cells are more often found than cell clumps and that expression of cell adhesion molecules on these cells is very weak or absent $(1,23)$. In peritoneal fluid macrophages in an advanced stage of differentiation have been found (24). These macrophages are known to produce several neutral proteases such as collagenase (25). Collagenase-like activity may affect structure and function of adhesion molecules in cells of the peritoneal fluid. Loss of expression and subsequent loss of intercellular adhesion may be one of the initial mechanisms to affect endometrial cells in peritoneal fluid and to prevent their adhesion to the peritoneum. 


\section{Acknowledgements}

The authors thank Setsuo Hirohashi, M.D. (National Cancer Center Research Institute, Tokyo, Japan) for providing the monoclonal antibody NCC-CAD-299 against human P-cadherin, Amoud Sonnenberg, Ph.D. (Central Laboratory of The Netherlands Red Cross Transfusion Service, Amsterdam, The Netherlands) for providing the monoclonal antibodies IOG11, J143 and G0H3 and Carl Figdor, Ph.D. (Department of Tumor immunology, Academic Hospital Radboud, Nijmegen, The Netherlands) for providing the monoclonal antibodies HP2/1 and SAM-1. We are indebted to Mrs. Edith P.M. van der Linden and to Jack P.M. Cleutjens, Ph.D. for their expert technical advises. 


\section{References}

1. van der Linden PJQ, de Groeij AFPM, Dunselman GAd, van der Linden EPM, Ramaekers FCS, Evers ILH. Expression of integrins and E-cadherin in cells from menstrual effluent, endometrium, peritoneal fluid, peritoneum and endometriosis. Ferti] Steril 1994; 61: 85-90.

2. van der Linden PJQ, de Groeij AFPM, Dunselman GA I, Arends JW, Evers JLH. $P$-cadherin expression in human endometrium and endometriosis. Gynaecol Obstet Invest 1994; $38: 183-185$.

3. Tabibzadeh $\mathbf{S}$. Patterns of expression of integrin molecules in human endometrium throughout the menstrual cycle. Hum Reprod $1992 ; 7: 876-882$.

4. Lessey BA, Damjanovich L, Coutifaris C, Castelhaum, Albelda SM, Buck CA. Integrin adhesion molecules in the human endometrium. Correlation with the normal and abnormal menstrual cycle. J Clin Invest 1992; 90; 188-195.

5. Cunha GR, Lung B. The importance of stroma in morphogenesis and functional activity of urogenital epithelium. In Vitro 1979; 15: 50-71.

6. Cunha GR, Bigsby RM, Cooke PS, Sugimura Y. Stromal epithelial interactions in adult organs. Cell Diff 1985; 17: 137-148.

7. Sampson JA. The development of the implantation theory for the origin of peritoneal endometriosis. Am J Obstet Gynecol 1940; 40: 549-557.

8. Birkenfeld A, Ezra Y, Ron D, et al. Indication of selective growth of human endometrial epithelial cells on extracellutar matrix. In Vitro Cell Dew Biol $1988 ; 24$ : $1188-1192$.

9. Negami AI, Tominaga T. Gland and epithelium formation in vitro from epithellial cells of the human endometrium. Hum Reprod 1989; 4: 620-624.

10. Dudley DJ, Hatasaka HH, Branch DW, Hammond E, Mitchell MD. A human endometrial explant system: Validation and potential applications. Am J Obstet Gynecol 1992; 167: 1174-1180.

11. Siegfried JM, Nelson KG, Martin JL, Kaufman DG. Histochemical identification of cultured cells from human endometrium. In Vitro $1984 ; 20: 25-32$.

12. Schatz F, Gordon RE, Laufer N, Gurpide E. Culture of human endometrial cells under polarizing conditions. Differentiation 1990; 42: 184-190.

13. Liotta LA, Lee $\mathbf{C W}$, Morakis DJ. New method for preparing large surfaces of intact. human basement membrane for tumor invasion studies. Cancer Letters 1980; 11 : $141-152$.

14. De Brü̈e AP, Dinjens WNM, van der Linden EPM, Pijls MMI, Moerkerk PT, Bosman FT. Extracellular matrix components induce endocrine differentiation in vitro in NCI-H716 cells. Am J Path 1993; 142: 773-782.

15. Takeichi $M$. The cadherins: cell - cell adhesion molecules controlling animal morphogenesis. Development 1988; 102: 639-655.

16. Inowe $\mathbf{M}$, Ogawa $\mathbf{H}$, Miyata $\mathbf{M}$, Shiozaki $\mathrm{H}$, Tanizawa O. Expression of E-cadherin in normal, benign, and malignant tissues of female genital organs. Am $J$ Clin Pathol 1992; 98: 76-80.

17. Frixen UH, Behrens J, Sachs M, Eberle G, Voss B, Warda A, Löchner D, Birchmelier W. E-Cadherin mediated cell-cell adhesion prevents invasiveness of human carcinoma cells. J Cell Biol 1991; 113: 173-185. 


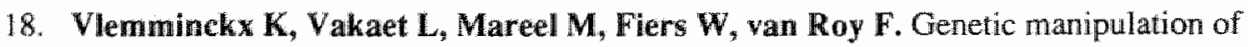
E-Cadherin expression by epithelial tumor cells reveals an invasion suppressor role. Cell 1991; 66: 107-119.

19. Hashimoto $\mathbf{M}$, Niwa $\mathbf{O}$, Nitta $\mathbf{Y}$, Takeichi $\mathbf{M}_{3}$ Yokoro $\mathbf{K}$. Unstable expression of E-Cadherin adhesion molecules in metastatic ovarian tumor cells. Ipn J Cancer Res $1989 ; 80: 459-463$.

20. van der Linden PJQ, de Goeij AFPM, Dunselman GAJ, Erkens HWH, Evers JLH. Expression of cadherins and integrins in human endometrium throughout the menstrual cycle. Fertil Steril 1995; 63:1210-1216.

21. Lessey BA, Castelbaum AJ, Buck CA, Lei Y, Yowell CW, Sun J. Further characterzation of endometrial integrins during the menstrual cycle and in pregnancy. Fertil Steril 1994; 62: 497-507.

22. Thie M, Albers A, Fuchs P, Denker HW. Integrins in the human endometrial cell lines, RL95-2 and AN3CA. Journal of Reproduction and Fertility 1993, abstract series number 12: 45.

23. van der Linden PJQ, Dunselman GAJ, de Goeij AFPM, van der Linden EPM, Evers JLH, Ramaekers FCS. Epithelial cells in peritoneal fluid: of endometrial origin? Am J Obstet Gynecol 1995; 173: 566-570.

24. Dunselman GAJ, Hendrix MGR, Bouckaert PXJM, Evers JLH. Functional aspects of peritoneal macrophages in endometriosis of women. $J$ Reprod Fertil 1988; 82: $707-710$.

25. Nathan CF. Secretory products of macrophages. J Clin Invest 1987; 79: 319-326. 


\section{Chapter 8}

\section{Endometrial cell adhesion in an in vitro model using intact amniotic membranes}

P.J.Q. van der Linden, A.F.P.M. de Goeij, G.A.J. Dunselman, H.W.H. Erkens and J.L.H. Evers

Fertility and Sterility 1995, in press

(reprinted with permission) 


\section{Abstract}

Objective: To study adhesion between endometrial tissue and peritoneum using intact amniotic membranes as an in vitro model.

Design: A cell biological and immunohistochemical study.

Setting: Tertiary-care university medical center.

Patients: Ten patients with regular and ovulatory cycles.

Interventions: Mechanically dissected tissue fragments from endometrial biopsies were cultured on either side of intact amniotic membranes. Also the carcinoma cell lines RL95-2 and AN3CA were used.

Main Outcome Measures: The adhesion of endometrial fragments and of endometrial carcinoma cell lines to amniotic membrane was studied in vitro and evaluated using frozen sections. The composition of the extracellular matrix and the presence of intermediate filament proteins of amniotic membrane were determined using immunohistochemistry and compared with those of normal peritoneum.

Results: Peritoneum and amniotic membrane were similar with respect to expression of cytokeratins in epithelial lining and of extracellular matrix (ECM) components. The endometrial fragments did not adhere to the intact epithelial side of the amniotic membrane. In contrast, adhesion did occur to the nonepithelial side of the amnion. The carcinoma cell lines RL95-2 and AN3CA adhered to either side of intact amniotic membranes.

Conclusions: An intact epithelial lining prevents adhesion of endometrial fragments to the ECM of amniotic membranes in vitro. An intact epithelium could be an important defense mechanism in preventing initial adhesion of retrogradely shed endometrium fragments to peritoneum.

\section{Introduction}

According to the implantation theory, endometrial tissue fragments and cells are shed into the peritoneal cavity by retrograde menstruation and may develop into endometriosis (1). Adhesion of endometrial cells to the peritoneum is considered important in the pathogenesis of endometriosis $(2,3)$. The relevance of isolated stromal or epithelial cell cultures in the study of endometriosis has been questioned, due to differences in biological behavior, including adhesion and outgrowth, between isolated cells and fragments in vitro (4). It is not clear whether epithelial or stromal cells of the endometrium adhere to the peritoneum. In addition, the adhesion of endometrial cells may occur directly to the mesothelium, the epithelial lining of the peritoneum. Alternatively, the cells may adhere to one or more extracellular matrix components of the peritoneum, which requires exposure of the extracellular matrix, e.g. by peritoneal damage. The 
peritoneum is a continuous membrane, lining the virtual space between the intra-abdominal viscera and the abdominal wall. In the female it is interrupted only by the lumina of the fallopian tubes. The surface is constituted of a single layer of epithelial cells anchored to a basement membrane which lies on layers of collagen and elastic tissue. The mesothelial nuclei are small and centrally located with a homogeneous chromatin pattern, usually without a nucleolus (5). Intact normal peritoneum is not easily available for in vitro studies due to its extreme friability and susceptibility to physical damage.

Amniotic membranes have been used to serve as a model for basement membrane after stripping of their epithelial lining (6). Amnion, the innermost layer of the amniotic cavity, is covered by a single layer of epithelial cells which are usually cuboidal but could be columnar over the placenta or flattened to squamous cells on the reflected amnion $(7,8,9)$. The epithelium is attached by hemidesmosomes to the basement membrane, which covers a loose avascular stroma composed of interstitial collagen and elastin (6). Most basement membranes share the same ground structure and type IV collagen forms the structural backbone to which other components like laminin and heparan sulphate proteoglycan are anchored (10).

The aim of this study was to investigate the adhesion between endometrial fragments and peritoneum using intact amniotic membranes as an in vitro model for peritoneum. Amniotic membranes allow study of adhesion to one side (epithelium) and/or the other (extracellular matrix) separately. To this end tissue fragments obtained from normal endometrium and endometrial carcinoma cell lines were cultured on either side of intact amniotic membranes. Extracellular matrix components and intermediate fillament proteins present in amniotic membranes were detected using immunohistochemistry and their expression was compared to normal peritoneum.

\section{Materials and methods}

\section{Tissue and cells}

Endometrium samples were collected from 10 patients using a Probet endometrial sampling device (Gynetics, Oisterwijk, The Netherlands) during a diagnostic laparoscopy, as part of their subfertility work-up. All women had a regular and ovulatory cycle, as demonstrated by ultrasound and an adequate rise of progesterone in the luteal phase of the cycle. All samples were collected during the early follicular phase of the cycle (day 2-5). The endometrium biopsies were washed in phosphate-buffered saline (PBS) to remove debris and blood cells. The carcinoma cell lines RL95-2 and AN3CA were obtained from ATCC, Rockville, Maryland, USA. 
Culture medium

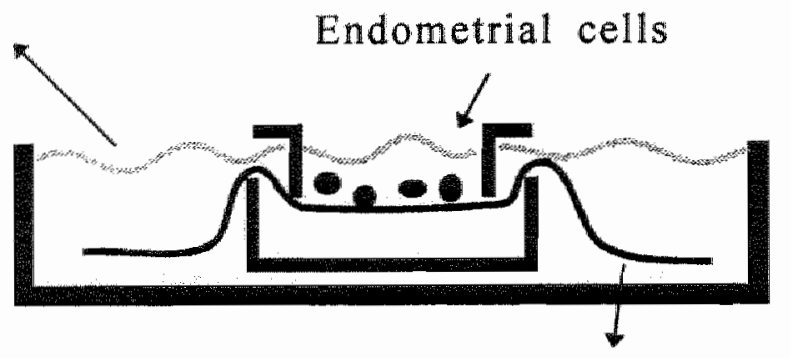

Amniotic membrane

Figure 1

Amniotic membrane suspended between two metal rings

Fresh human placentas were obtained at the time of normal term delivery. The amnion was separated from the chorion. The membranes were suspended between two metal rings (Fig. 1).

The endometrium samples were gently dissected by scalpel into small pieces. Cell clumps were dispersed by aspiration through a pasteur pipette. Representative samples of peritoneum were obtained at the time of laparotomy in two patients, in their reproductive years, operated for benign conditions.

\section{Cell culture}

The tissue fragments were layered on the amniotic membrane and cultured for 24 hours at $37^{\circ} \mathrm{C}$ using DMEM/F-12, consisting of equal parts of Dulbecco's Modified Eagle's minimal essential medium (DMEM, Flow Laboratories, Zwanenburg, The Netherlands) and HAM F-12 (Flow Laboratories, Zwanenburg, The Netherlands). The medium was supplemented with $10 \%$ charcoal stripped fetal calf serum (FCS, Boehringer, Mannheim, Germany) and with 100 $\mathrm{U} / \mathrm{mL}$ penicillin, $100 \mu \mathrm{g} / \mathrm{mL}$ streptomycin and $2.5 \mu \mathrm{g} / \mathrm{mL}$ amphotericin B. Each sample of tissue fragments was cultured on either side of the amniotic membrane. The carcinoma cell line RL95-2 was cultured in DMEM/F-12 with 5\% FCS and AN3CA in MEM with 1\% non-essential amino acids, $1 \%$ pyruvate and $1 \% \mathrm{~L}$-glutamate, without antibiotics, as recommended by ATCC. The carcinoma cell lines were also cultured on either side of the suspended amniotic membranes. After culturing for 24 hours the suspended amniotic membranes were washed with phosphate-buffered saline (PBS), to prevent a false impression of adhesion, as we have observed with unwashed membranes. The amniotic membrane cultures were snap frozen in isopentane embedded in dry ice. All samples were 
stored at $-70^{\circ} \mathrm{C}$ until analyzed. Hematoxylin-eosin slides were prepared to study the morphology and the adhesion of the endometrial fragments to the amniotic membranes.

\section{Immunohistochemistry}

Cryostat sections of $5 \mu \mathrm{m}$ thickness were prepared of amnion and mounted on slides. The sections were air-dried and fixed with methanol at $-20^{\circ} \mathrm{C}$ for one minute, followed by an acetone dip at $-20^{\circ} \mathrm{C}$. Slides were washed three times for 5 minutes in PBS, and immersed in $0.3 \%$ hydrogen peroxide to block endogenous peroxidase activity. The sections were washed again three times for 5 minutes in PBS and then preincubated with diluted normal goat serum (1:5) for 15 minutes. A series of mouse monoclonal antibodies was used including MAB042 against fibronectin (Chemicon, El Segundo, CA), 1042 against collagen type IV (11) and MAB458 against heparan sulphate proteoglycan (HSPG) (Chemicon, El Segundo, CA). Also the rabbit polyclonal antibody 4 E10 against laminin was used (12). Furthermore the mouse monoclonal antibodies RV 202 for vimentin, RCK 106 for cytokeratin 18, RCK 108 for cytokeratin 19 were used (13). Incubation with primary antibodies was done in appropriate dilutions for 1 hour at $37^{\circ} \mathrm{C}$. After washing three times for 10 minutes in PBS, the sections with the mouse monoclonal antibodies were incubated for 60 minutes with rabbit-antimouse immunoglobulin $\mathrm{G}$ (IgG) conjugated with horseradish peroxidase (Dako A/S, Glostrup, Denmark). The sections with the rabbit polyclonal antibody were incubated for 60 minutes with goat-antirabbit $\mathrm{IgG}$ conjugated with horseradish peroxidase (Nordic, Tilburg, The Netherlands). Antibody binding was visualized using 3'-3-diaminobenzidine and hydrogen peroxide. The slides were counterstained with hematoxylin. Stained slides were dehydrated through alcohols, cleared in xylene and mounted in Entellan for light microscopy. Negative controls included sections stained without the primary antibody, using PBS instead.

\section{Results}

In the amniotic epithelial cells the nuclei were relatively large. In sections from the normal peritoneum the nuclei were small and centrally located. The epithelial cells had a clear cytoplasm and sharply defined cell borders (Fig. 2). Amniotic membranes showed immunohistochemical staining of the extracellular matrix components fibronectin, collagen type IV, laminin and HSPG. Collagen type IV and HSPG were seen as a small intensely stained line under the epithelial cells as is shown in figure 3. The epithelial lining of the amniotic membrane showed immunohistochemical staining for the epithelial markers cytokeratin 18 and 19 . 


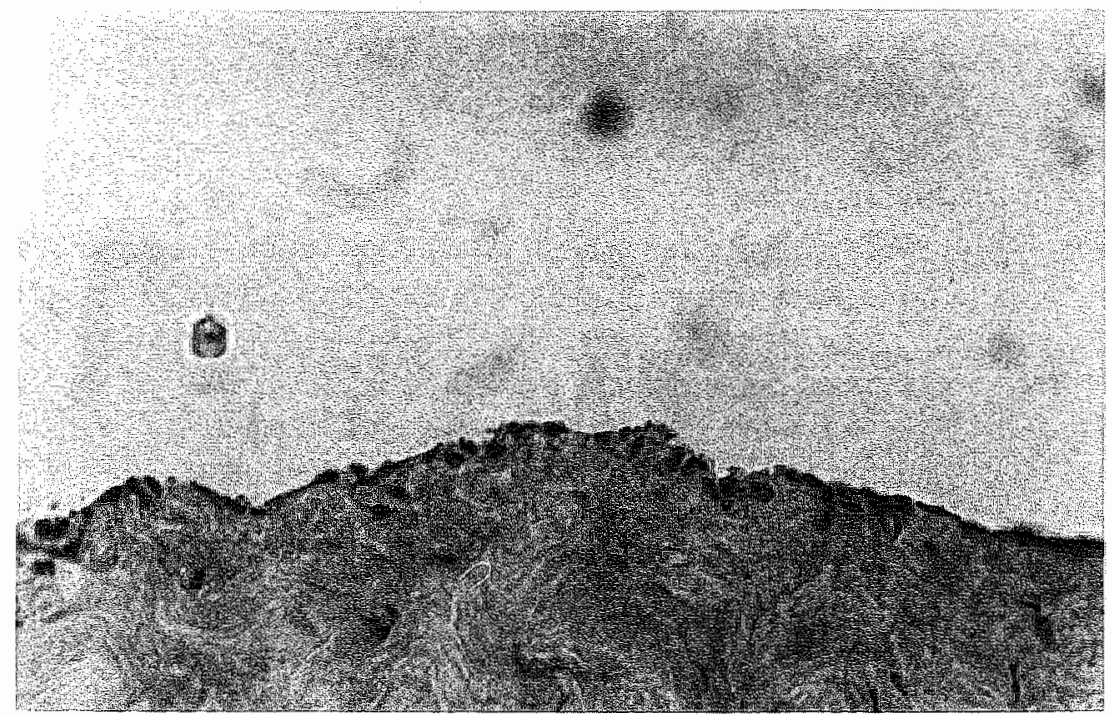

Figure 2

Section of normal peritoneum stained with hematoxylin-eosine. The epithelial cells have a clear cytoplasm and sharply defined cell borders. The nuclei are small and centrally placed.

No positive staining was found with the monoclonal. antibody RV202 against vimentin. This was also found for the peritoneum.

The endometrial fragments showed adhesion to the non-epithelial side of the amniotic membrane in all cases $(n=10)$. Both the epithelial as well as the stromal components of the endometrial fragments appeared to adhere. Adhesion to the intact epithelial side of the amnion was not observed in any case $(n=10)$. The carcinoma cell lines RL95-2 and AN3CA adhered to either side of the suspended amniotic nembranes. No difference was apparent in the number of cells that adhered to either side of the amniotic membranes.

\section{Discussion}

Amniotic membranes show a remarkable resemblance with the peritoneal lining. The amnion can be considered as composed of a single layer of epithelial cells layered over and intimately attached to an underlying zone of fibrous connective tissue (6). The amniotic epithelium attaches to the basement membrane by hemidesmosones. The epithelial cells of the reflected surface of the amnion are generaly cuboidal, whereas those of the placental surface are mainly columnar. 

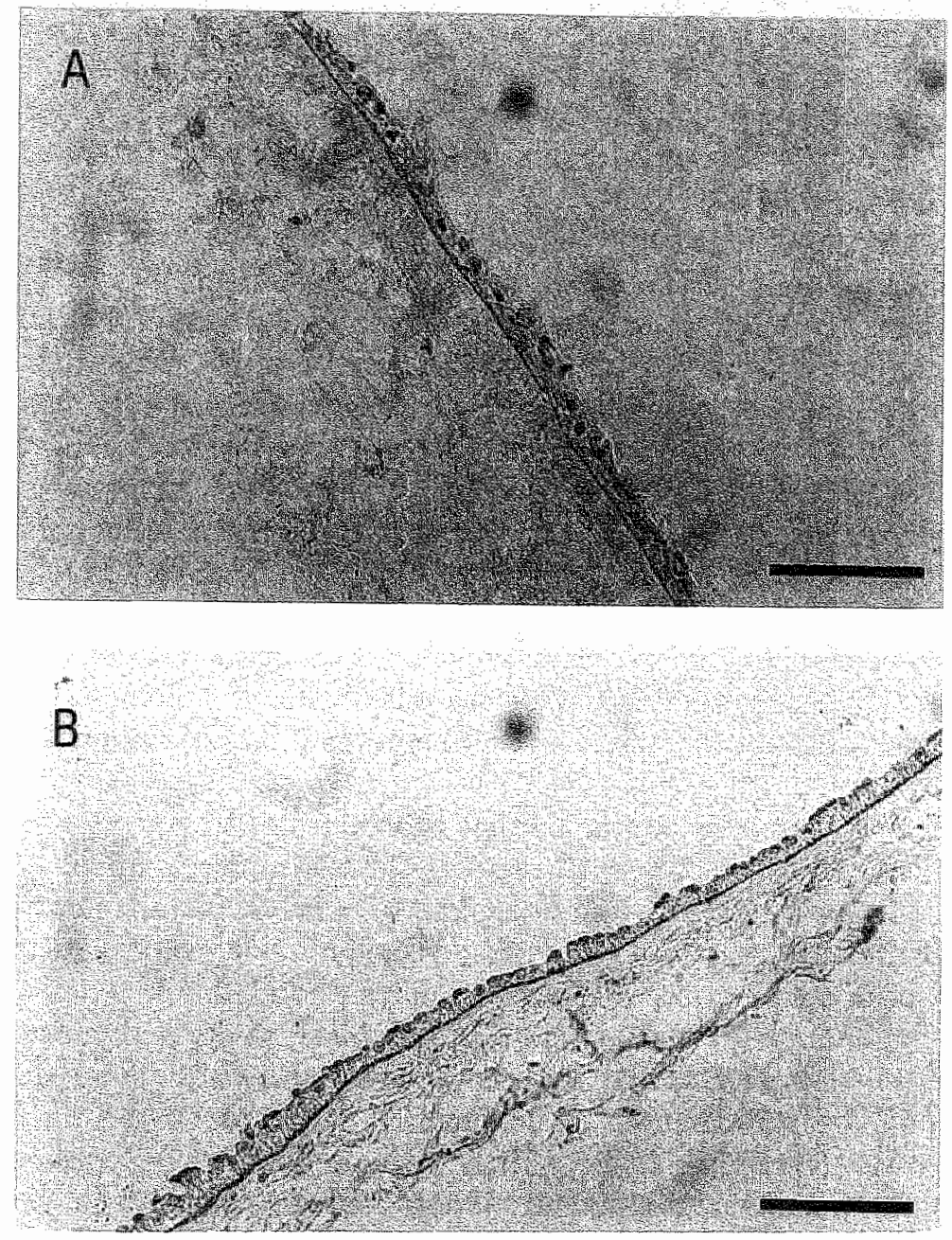

Figure 3

(A), Amniotic membrane stained for collagen type IV with monocional antibody 1042. (B), Amniotic membrane stained for heparan sulphate proteoglycan with monoclonal antibody MAB458. Staining is seen as a clear dark line under the epithelium. Bar indicates $55 \mu \mathrm{m}$.

The amniotic membrane and the peritoneum are both lined with a single layer of epithelial cells. Although some minimal differences in the cytological appearance of the amniotic and the peritoneal epithelium are present, there are many similarities. They both show expression of intermediate filament proteins such as cytokeratin 18 and 19 and no expression of vimentin. The submesothelial 
layer is composed of collagen, elastin and other extracellular proteins. The composition of the main constituents of the extracellular matrix (fibronectin, laminin, collagen type IV, HSPG) of peritoneum and of amnion is very similar as is shown with immunohistochemistry. Their submesothelial layers also contain collagen type I and III (5).

Our study shows that endometrial fragments do not adhere to the epithelial side of intact amniotic membranes. In contrast, these fragments do adhere to the stromal side. Furthermore, stromal as well as epithelial cells of the endometrium were found to be involved in this adhesion. Wild et al. (4) suggested that whole endometrial fragments started adhering to an intact mesothelial layer in vitro within 24 hours. They did, however, not prepare cryosections in these first 24 hours, but only documented adherence by phase contrast microscopy. It is possible that observations under phase contrast give a false impression of adherence. We have found that proper washing of the amniotic membrane culturing system is essential to detect true adhesion.

An intact epithelial lining did not prevent adhesion of endometrial carcinoma cell lines. This suggests that the adhesion behavior of endometrial carcinoma cells in the process of metastasis is different from that of normal endometrial fragments.

We did not see adhesion of normal endometrium fragments to intact epithelium, whereas these fragments readily adhere to amniotic membranes which are devoid of epithelium (14). Peritoneum and amniotic membrane show a great similarity in structure and in morphological and immunohistochemical features. We therefore suggest that an intact peritoneal mesothelium prevents adhesion between endometrial cells shed into the peritoneal cavity and the peritoneum. This adhesion is one of the first steps required, according to the theories concerning the pathogenesis of endometriosis that are based on retrograde menstruation. Disruption of the peritoneal lining seems to be a prerequisite for adhesion between endometrial cells and the peritoneal wall. This would be in accordance with the fact that endometrial tissue growing on the peritoneal surface has never been described (15). Endometriosis is presumably not an all-or-none phenomenon. A delicate equilibrium seems to exist between attacking forces (retrograde menstruation) and defense mechanisms. On the one hand the amount and the nature of the regurgitated menstrual debris is important in the development of the disease (16). On the other hand one of the first lines of defense reported is the active intra-abdominal milieu with activated macrophages (17). If these cells are impaired in their disposing of the regurgitated cells or if the number of regurgitated cells is too large, the surviving cells can adhere to the peritoneal lining. An intact peritoneal lining may be an important additional line of defense. If all defense mechanisms fail, endometriosis may develop. 


\section{Acknowledgements}

The authors thank Jack P.M. Cleutjens, Ph.D. for his expert advises. 


\section{References}

1. Sampson JA. The development of the implantation theory for the origin of peritoneal endometriosis. Am I Obster Gynecol 1940; 40:549-557.

2. van der Linden PJQ, de Goeij AFPM, Dunseliman GAJ, van der Linden EPM, Ramaekers FCS, Evers JLH. Expression of integrins and E-cadherin in cells from menstrual effluent, endometrium, peritoneal fluid, peritoneum and endometriosis. Fertil Steril 1994; 61: 85-90.

3. vain der Linden PJQ, de Goeij AFPM, Dunselman GAJ, Arends JW, Evers JLH. P-cadherin expression in human endometrium and endometriosis. Gynaecol Obstet Invest $1994 ; 38: 183 ; 185$.

4. Wild RA, Zhang $\mathbf{R}$, Medders $\mathbf{D}$. Whole endometrial fragments form characteristics of in wivo endometriosis in a mesothelial cell co-culture system: an in vitro model for the study of the histogenesis of endometriosis. J Soc Gynecol Invest 1994; 1: 65-68.

5. Carter D, True L, Otis CN. Serous membranes. In: Sternberg SS, editor. Histology for Pathologists. New York: Raven Press, Ltd, 1992: 499-513.

6. Liotta LA, Lee CW, Morakis DJ. New method for preparing large surfaces of intact human basement membrane for tumor invasion studies. Cancer Letters 1980; 11: $141-152$.

7. Danforth DN, Hull RW. The microscopic anatomy of the fetal membranes with particular reference to the detailed structure of the amnion. Am J Obstet Gynecol 1958; 75: $536-550$.

8. Bourne GL. The microscopic anatomy of the human amnion and chorion. Am J Obstet Gynecoll 1960; 79: 1070-1073.

9. Thomas CE. The ultrastructure of human amnion epithelium. J Ultrastruct Res 1965; 13: $65-84$.

10. Bosman FT, Havenith MG, Cleutjens JPM. Basement membranes in cancer. Ultrastruct Pathol 1985; 8: 291-304.

11. Havenith MG, Cleutjens JPM, Beek C, van der Linden E, de Goejj AFPM, Bosman FT. Human specific anti-type IV collagen monoclonal antibodies, characterization and immunohistochemical application. Histochemistry 1987; 87: 123-128.

12. Wewer U, Albrechtsen R, Manthorpe M, Varon S, Engvall E, Ruoslahti E. Human laminin isolated in a nearly intact, biologically active form from placenta by limited proteolysis. J Biol Chem 1983; 258: 12654-12660.

13. van Niekerk CC, Ramaekers FCS, Hanselaar AGJM, Aldeweirdt J, Poels LG. Changes in expression of differentiation markers between normal ovarian cells and derived tumors. Am J Pathol 1993; 142: 157-177.

14. van der Linden PJQ, de Goeij AFPM, Dunselman GAJ, Erkens HWH, Evers JLH. Amniotic membrane as an in vitro model for endometrium extracellular matrix interactions. Submitted for publication.

15. Brosens I, Puttemans PJ, Deprest J. Appearances of endometriosis. Baill Clin Obstet Gynaecol 1993; 7: 741-757.

16. Olive DL, Henderson DY. Endometriosis and Müllerian anomalies. Obstet Gynecol $1987 ; 69: 412415$.

17. Dunselman GAJ, Hendrix MGR, Bouckaert PXJM, Evers JLH. Functional aspects of peritoneal macrophages in endometriosis in women. J Reprod Fertil 1988; 82: 707-710. 
Chapter 9

General discussion 
In the pathogenesis of endometriosis the classical implantation theory of Sampson (1) still remains the most widely accepted theory to explain the development of this enigmatic disease. Nevertheless definite proof is still lacking. The conditions that have to be met for this theory are threefold, firstly, retrograde menstruation has to occur, secondly, retrograde menstruation should contain viable endometrial cells, and, thirdly, adhesion to the peritoneum has to occur with subsequent implantation and proliferation.

In chapter 3, we have demonstrated the presence of endometrial cells in peritoneal fluid using immunohistochemistry. We have compared the immunohistochemical staining properties of these fragments to those of cells present in endometrium, menstrual effluent, peritoneum and endometriotic lesions. The staining characteristics, based on the application of monoclonal antibodies against various epithelial markers in cells from menstrual effluent, endometrium, peritoneal fluid, and endometriotic lesions were remarkably similar. Kruitwagen et al. (2) have demonstrated that peritoneal fluid of women with patent tubes contains viable cells of endometrial origin. Our study showed that peritoneal fluid contains single epithelial cells, rather than endometrial tissue fragments in women with patent tubes. Possibly endometrial epithelial cells after having left the uterine cavity, are modulated in the peritoneal cavity prior to developing into an endometriotic lesion. Our study provides new evidence for the asssumption that reflux menstrual detritus is important in the development of endometriosis in women with patent tubes.

We have focussed our attention on cell adhesion molecules (CAMs), more specifically on cadherins and integrins. Cadherins are considered the most important CAMs involved in cell-cell adhesion and integrins for cell-extracellular matrix (ECM) interactions.

In chapter 4 and 5 , we have demonstrated that integrins $\alpha 2 \beta 1, \alpha 3 \beta 1, \alpha 4 \beta 1$, $\alpha 5 \beta 1$, and $\alpha 6 \beta 1$ and E-cadherin are expressed in endometriotic lesions as well as in cells and tissues that are potentially involved in the development of endometriosis. Regurgitated cells obtained from peritoneal fluid showed expression of cell adhesion molecules, particularly E-cadherin and some $\beta 1$ integrins, but to a lesser extent than the cells from the tissues, they are supposed to stem from. The expression pattern of CAMs suggests that the loss of cell adhesion properties could be involved in the shedding of endometrial tissue during menstruation and the attachment of endometrial tissue fragments to the peritoneum. The demonstration of CAMs in menstrual effluent, endometrium, peritoneal fluid, as well as in endometriotic lesions, is no strict evidence that endometriosis originates from endometrium by retrograde shedding of viable tissue fragments. However, all cells potentially involved in the pathogenesis of endometriosis, express members of the integrin and cadherin families of cell adhesion molecules. Effective cellular adhesion requires that a cell coordinates 
the action of its various adhesion molecules. It is, therefore, not to be expected that in the pathogenesis of endometriosis the processes of adhesion of shed endometrial tissue can be explained by the mere presence or absence of one single cell adhesion molecule.

$\mathrm{E}$ - and $\mathrm{P}$-cadherin are presumably functionally involved in the maintenance of epithelial structures in endometrium and endometriosis, both during the proliferative and the secretory phase of the cycle. E- and P-cadherin expression was detected in all cycle phases in endometrial samples and did not vary throughout the menstrual cycle as was shown in chapter 6 . If these adhesion molecules are functionally involved in the cyclic menstrual shedding, the loss of expression is limited to a short period of time. Of the $\beta 1$ integrins, only $\alpha 2 \beta 1$ expression was modulated during the menstrual cycle, as it was only absent in the midluteal phase. No relation was found between the expression of cell adhesion molecules and the expression of estrogen receptor and progesterone receptor or the serum levels of progesterone and estradiol. The differences that were noted with previous reports $(3,4)$ with respect to the cycle dependency of integrins, could be due to a better determination of the cycle phase or to the use of different monoclonal antibodies. It is plausible that different antibodies are detecting different epitopes of the same antigen. In a comparative study on endometrium samples from well defined cycle phases, particularly from the early follicular phase and from the midluteal phase, we compared the monoclonal antibodies that were used by Lessey et al. (3) and those that were used in our own studies. We confirmed a monoclonal antibody-specific staining pattern for the integrins $\alpha 4 \beta 1$ and $\alpha 2 \beta 1$ respectively (5).

Since cadherins and $\beta 1$ integrins could be detected in late luteal phase endometrium, these cell adhesion molecules could be involved in the attachment of endometrial fragments to the peritoneal lining as a result of retrograde menstruation. The functional involvement of these CAMs remains to be clarified.

To better understand the process of endometrial tissue adhesion to extracellular matrix (ECM), we developed an in vitro model using amniotic membranes and isolated components of extracellular matrix coated on glass, as was discussed in chapter 7 . Stripped amniotic membranes proved to be a valid model to study interactions between endometrial cells and ECM. Also adhesion behavior of established carcinoma cell lines could be studied using this model.

One important observation was the loss of cell adhesion molecule expression, parallelled by loss of adhesion to stripped amniotic membranes, of endometrial cells after collagenase digestion. Apparently collagenase destroys both structure and function of cell adhesion molecules at the cellular surface. This strongly suggests a functional role of one or more of these cell adhesion molecules in endometrial cell-ECM interactions. Endometrial cells obtained after collagenase 
digestion have lost functional cell adhesion properties and hence are less suitable to study the initial phases of adhesion in vitro.

The results of this study were in accordance with the observations in chapter 3 and 4 that in peritoneal fluid single cells are more often observed than cell clumps and that expression of cell adhesion molecules on these cells is very weak or absent. Proteolytic activity in peritoneal fluid may affect structure and function of adhesion molecules in regurgitated endometrial cells. Loss of expression of cell adhesion molecules and subsequent loss of intercellular adhesion may be one of the initial defense mechanisms in the peritoneal cavity that affect endometrial cells in peritoneal fluid. This may have a twofold effect, it prevents their adhesion to the peritoneum, and facilitates at the same time their removal and destruction by peritoneal macrophages.

To investigate the adhesion between endometrial fragments and cells to an ECM covered by an intact epithelium, intact amniotic membranes were used.

Another important observation was the absence of adhesion of endometrium to intact amniotic membrane. No adhesion of fragments of normal endometrium to intact epithelium was found, whereas these fragments readily adhered to amniotic membranes which were denuded of their epithelium. Peritoneum and amniotic membrane show a great similarity in structure and in morphological and immunohistochemical features. We therefore suggest that an intact peritoneal mesothelium prevents adhesion between endometrial cells shed into the peritoneal cavity and the peritoneum. Carcinoma cell lines did show adhesion to intact epithelium. This suggests that the adhesive behavior of endometrial carcinoma cells in the process of metastasis is different from that of normal, shed endometrial fragments.

Disruption of the peritoneal lining seems to be a prerequisite for adhesion between endometrial cells and the peritoneal wall. This would be in accordance with the fact that endometrial tissue growing on the peritoneal surface has never been described (6).

The findings of the present study support the contention that in endometriosis, a delicate equilibrium exist between attacking forces (retrograde menstruation) and defense mechanisms. On the one hand, the amount and the nature of the regurgitated menstrual debris is important in the development of the disease (7). On the other hand, one of the first lines of defense reported is the collagenaselike activity of peritoneal fluid and the active intra-abdominal milieu, characterized by activated macrophages (8). If these cells are impaired in their disposing of the regurgitated cells, or if the number of regurgitated cells is too large, the surviving cells can adhere to exposed ECM in damaged peritoneal lining. An intact peritoneal lining may be an important additional line of defense. If all defense mechanisms fail, endometriosis will develop. 


\section{Future perspectives}

The detection of expression of CAMs on cells, potentially involved in the pathogenesis of endometriosis, and the correlation between expression of CAMs and adhesion in vitro, does support their functional role in the processes involved. Future research should be directed towards finding how these processes can take place, instead of why. Therefore, it should be focussed on interfering with this adhesion process. The question that has to be answered is if this process can be influenced by manipulating the expression and function of CAMs by molecular biological techniques. One way of interfering could be blocking of expression at the gene level, e.g. with molecular biological manipulation such as antisense oligonucleotides to inhibit transcription. Another way could be specific inhibition of function at the protein level with antibodies against CAMs.

Also the effects of steroid hormones and peptides on cell adhesion remain to be elucidated.

The observed effect of collagenase activity in vitro on endometrial fragments and the suggestion that this could be a first step in disposing of the retrogradely shed endometrial fragments, should be subject of future studies.

The role of an intact epithelium in preventing adhesion of endometrial fragments in vitro to ECM deserves attention. To study this phenomenon in an in vitro model, isolated mesothelium cells could be cultured as monolayers on ECM. Endometrial fragments could then be layered on this model for peritoneum and be tested for adhesion. These endometrial fragments should be gained preferably from shed endometrium either from peritoneal fluid or from antegrade menstrual effluent. In doing so the model would mimic the actual phenomenon as closely as possible. It would allow for repeated, prospective observations of the delicate processes involved in the adhesion between regurgitated endometrial cells or fragments and peritoneum. 


\section{References}

1. Sampson JA. Peritoneal endometriosis due to the menstrual dissemination of endometrial tissue into the peritoneal cavity. Am J Obstet Gynecol 1927; 14:422-469.

2. Kruitwagen RFPM, Poels LG, Willemsen WNP, de Ronde IJY, Jap PHK, Rolland R. Endometrial epithelial cells in peritoneal fluid during the early follicular phase. Fertill Steril 1991; 55: 297-303.

3. Lessey BA, Damjanovich L, Coutifaris C, Castelbaum A, Albelda SM, Buck CA. Integrin adhesion molecules in the human endometrium. Correlation with the normal and abnomal menstrual cycle. J Clin Invest 1992; 90: 188-195.

4. Tabibzadeh $\mathbf{S}$. Patterns of expression of integrin molecules in human endometrium throughout the menstrual cycle. Hum Reprod 1992; 7: 876-882.

5. van der Linden PJQ. Unpublished observations.

6. Brosens I, Puttemans PJ, Deprest J. Appearances of endometriosis. Baill Clin Obstet Gynaecol 1993; 7: 741 757.

7. Olive DL, Henderson DY. Endometriosis and Müllerian anomalies. Obstet Gynecol $1987 ; 69: 412-415$.

8. Dunselman GAJ, Hendrix MGR, Bouckaert PXIM, Evers JLH. Functional aspects of pertitoneal macrophages in endometriosis in women. J Reprod Fertil 1988; 82: 707-710. 


\section{Summary}

In the first chapter the literature is reviewed with regard to the pathogenesis of endometriosis. The implantation or transplantation theory, that suggests implantation and subsequent growth of retrogradely shed viable endometrial cells, still remains the most widely accepted theory to explain the pathogenesis of endometriosis. The second part gives an overview of the literature on cell adhesion molecules, in particular cadherins and integrins, the most important cell adhesion molecules involved in cell-cell adhesion and in cell-extracellular matrix interactions respectively. Special interest is given to the possible functional role of these cell adhesion molecules in the human endometrium.

The aim of the thesis is outlined in chapter 2. The first goal was to better characterize retrograde menstruation. The second goal was to assess which sub-classes of cadherins and integrins are expressed in endometrial cells and other cells potentially involved in the pathogenesis of endometriosis. The third goal was to study functional cell adhesion in vitro.

In chapter 3 the immunohistochemical properties of epithelial cells in peritoneal fluid were examined and the staining characteristics were compared with cells of endometrium, menstrual effluent, peritoneum, and endometriotic lesions. All but one sample of menstrual effluent and peritoneal fluid cells stained positively with antibodies against vimentin, cytokeratin 18 and 19. The monoclonal antibody BW495/36, that stains endometrial epithelium, but is absent in mesothelium, stained 14 of 16 menstrual effluent samples and 9 of 16 peritoneal fluid cell samples. Endometriotic specimens stained with all markers. No major differences in staining properties were observed in menstrual effluent, endometrium and peritoneal fluid cells between patients with or without endometriosis. These results support the contention of transport of menstrual detritus to the peritoneal cavity in women with patent fallopian tubes.

In chapter 4 the expression of $\beta 1$ integrins, including $\alpha 2 \beta 1, \alpha 3 \beta 1, \alpha 4 \beta 1$, $\alpha 5 \beta 1$ and $\alpha 6 \beta 1$, and E-cadherin in cells from peritoneal fluid, endometrium, menstrual effluent, peritoneum and endometriotic lesions during the early follicular phase of the menstrual cycle was studied, using immunohistochemistry. All integrins tested could be detected in the endometrium samples and in endometriotic lesions. From the expression of these cell adhesion molecules, it was concluded that these cell adhesion molecules could be involved in the shedding of endometrial tissue during menstruation and the attachment of endometrial tissue fragments to the peritoneum. 
In chapter 5 the expression of $\mathbb{P}$-cadherin in human endometrium and endometriosis was studied and compared with the expression of E-cadherin, using immunohistochemistry. P-cadherin was detected in epithelial cells in all endometrial samples and in all glandular structures of endometriotic lesions. The staining characteristics for P-cadherin and E-cadherin were similar. It was suggested that P-cadherin is functionally involved in the maintenance of the proliferative compartment of endometrium and could have a comparable function in endometriotic lesions.

In chapter 6 cadherin and integrin expression was studied in biopsies of endometrium during well defined phases of the menstrual cycle, using immunohistochemistry in frozen sections. Simultaneously, blood samples were collected for estradiol and progesterone assay. The expression of cell adhesion molecules, including $\mathrm{E}$ - and P-cadherin and the integrins $\alpha 2 \beta 1, \alpha 3 \beta 1, \alpha 4 \beta 1$, $\alpha 5 \beta 1$ and $\alpha 6 \beta 1$, and the expression of estrogen receptor and progesterone receptor was determined. E- and P-cadherin expression was detected in all samples and did not vary throughout the menstrual cycle. If their expression is functionally involved in the cyclic menstrual shedding, the loss of expression is limited to a short period of time. Of the $\beta 1$ integrins, only $\alpha 2 \beta 1$ expression was modulated during the menstrual cycle and found to be absent in the midluteal phase. No relation was found between the expression of cell adhesion molecules and the expression of estrogen receptor and progesterone receptor. Since the cadherins and $\beta 1$ integrins could be detected in late luteal phase endometrium it was suggested that these cell adhesion molecules could be involved in the attachment of endometrial fragments to the peritoneal lining as a result of retrograde menstruation.

In chapter 7 an in vitro model was developped to study the interaction between endometrial cells and extracellular matrix (ECM) and the expression of cell adhesion molecules in endometrial cells and tissue fragments under in vitro conditions was evaluated. Endometrial biopsies were collected and were either digested using collagenase type 1 , or dissected mechanically. Adhesion of isolated cells and tissue fragments to stripped amniotic membranes and to coverslips coated with ECM components was studied. Also the steroid responsive endometrial carcinoma cell lines RL95-2 and AN3CA were used. The expression of $\beta 1$ integrins and cadherins was assessed using immunohistochemistry. Collagenase digestion of endometrial biopsies yielded viable single cells. These cells did not adhere to either side of stripped amniotic membranes, and did not show expression of the cell adhesion molecules. In contrast, mechanically fragmented endometrium samples adhered to both sides of stripped amniotic membranes and showed immunohistochemical expression of $\mathbb{E}$ - and P-cadherin and integrins $\alpha 2 \beta 1, \alpha 3 \beta 1, \alpha 4 \beta 1, \alpha 5 \beta 1$ and $\alpha 6 \beta 1$. The carcinoma cell lines RL95-2 and AN3CA adhered rapidly to amniotic mem- 
branes and to coverslips coated with ECM components. It was concluded that amniotic membranes, after stripping of epithelial lining, are suitable to study interactions between endometrial tissue and extracellular matrix in functional and structural studies. Endometrial cells after collagenase type I digestion are less suitable to study initial phases of adhesion due to loss of functional cell adhesion molecules. Carcinoma cell lines can serve as an in vitro model for the study of adhesion behavior.

In chapter 8 adhesion between endometrial tissue and peritoneum using intact amniotic membranes as an in vitro model was studied. Mechanically dissected tissue fragments from endometrial biopsies were cultured on either side of intact amniotic membranes. Also the carcinoma cell lines RL95-2 and AN3CA were used. Peritoneum and amniotic membrane were similar with respect to expression of cytokeratins in epithelial lining and of extracellular matrix (ECM) components. The endometrial fragments did not adhere to the intact epithelial side of the amniotic membrane. In contrast, adhesion did occur to the nonepithelial side of the amnion. The carcinoma cell lines RL95-2 and AN3CA adhered to either side of intact amniotic membranes. It was concluded that an intact epithelial lining prevents adhesion of endometrial fragments to the ECM of amniotic membranes in vitro. An intact epithelium could be an important defense mechanism in preventing initial adhesion of retrogradely shed endometrium fragments to peritoneum.

In chapter 9 an attempt is made to integrate the previous chapters with the existing literature and to outline some future perspectives. Future research should be focussed on interfering with the adhesion process, i.e. by specific inhibition of function of cell adhesion molecules at the protein level using antibodies. Further research should be directed towards the role of an intact epithelium in preventing adhesion of endometrial fragments to the mesothelium. 



\section{Samenvatting}

Endometriose is het voorkomen van functioneel endometriumachtig weefsel op andere plaatsen dan de baarmoederholte.

In het eerste hoofdstuk van dit proefschrift wordt een literatuuroverzicht gegeven van de pathogenese van endometriose. De implantatie of transplantatietheorie blijft de meest geaccepteerde theorie om de pathogenese van endometriose te verklaren. De implantatietheorie behelst implantatie en vervolgens groei van vitale endometrium cellen, die door retrograde menstruatie in de buikholte terechtkomen. Het tweede deel geeft een overzicht van de literatuur over celadhesiemoleculen, in het bijzonder de cadherines en de integrines. Deze celadhesiemoleculen zijn betrokken bij respectievelijk cel-celadhesie en bij cel-extracellulaire matrix-interacties. Er wordt speciale aandacht geschonken aan de mogelijke functionele rol van deze celadhesiemoleculen in het humane endometrium.

De doelstellingen van het beschreven onderzoek waren drieledig. Het eerste doel was het beter karakteriseren van retrograde menstruatie. Het tweede doel was het bepalen van de sub-klassen van cadherines en integrines die tot expressie komen in endometriumcellen en andere cellen die mogelijk betrokken zijn bij de pathogenese van endometriose. Het derde doel was het bestuderen van functionele celadhesie in vitro.

De immunohistochemische eigenschappen van epitheliale cellen in peritoneumvloeistof worden onderzocht en vergeleken met die van cellen van het endometrium, van het menstruum, van het peritoneum en van endometrioselaesies. Alle celmonsters van het menstruum en van de peritoneumvloeistof kleurden positief met antilichamen tegen vimentine en cytokeratine $18 \mathrm{en} 19$, op één na. Het monoclonale antilichaam BW495/36, dat endometriumepitheel wel kleurt, maar cellen van het peritoneum niet, kleurde 14 van de 16 celmonsters van het menstruum en 9 van de 16 celmonsters van de peritoneumvloeistof. Cellen in endometrioselaesies kleurden met alle merkstoffen. Er werden geen grote verschillen waargenomen in de kleuringen van de cellen van het menstruum, van het endometrium en van de cellen in de peritoneumvloeistof van patiënten met en zonder endometriose. Deze bevindingen maken aannemelijk dat transport van cellen uit het menstruum naar de peritoneale holte optreedt bij vrouwen met open tubae.

Met behulp van immunohistochemie wordt vervolgens de expressie van $\beta 1$-integrines, waaronder $\alpha 2 \beta 1, \alpha 3 \beta 1, \alpha 4 \beta 1, \alpha 5 \beta 1$ en $\alpha 6 \beta 1$, en E-cadherine onderzocht in cellen van peritoneumvloeistof, endometrium, menstruum, peri- 
toneum en endometrioselaesies gedurende de vroeg-folliculaire fase van de menstruele cylus. Alle integrines, die werden bestudeerd, werden aangetoond in de celmonsters van het endometrium en de endometrioseleasies. Op basis van de expressie van deze celadhesiemoleculen wordt geconcludeerd dat deze celadhesiemoleculen betrokken kunnen zijn bij het loslaten van endometriumweefsel tijdens de menstruatie en de aanhechting van endometriumfragmenten aan het peritoneum.

De expressie van P-cadherine wordt onderzocht in humaan endometrium en in endometrioselaesies en deze wordt vergeleken met de expressie van E-cadherine. P-cadherine werd aangetroffen in de epitheelcellen van alle endometriummonsters en in alle glandulaire structuren van endometrioselaesies. De kleuringskarakteristieken van P-cadherine en E-cadherine waren vergelijkbaar. Het is aannemelijk dat P-cadherine functioneel betrokken is bij de handhaving van het proliferatieve deel van het endometrium en dat het een vergelijkbare rol heeft in endometriosehaarden.

Voorts wordt de immunohistochemische expressie van cadherines en integrines bestudeerd in endometriumbiopten, die afgenomen zijn op goed gedefinieerde momenten van de menstruele cyclus. Tegelijkertijd werden bloedmonsters verzameld voor de bepaling van oestradiol en progesteron. De expressie van celadhesiemoleculen, waaronder E- en P-cadherine en de integrines $\alpha 2 \beta 1, \alpha 3 \beta 1, \alpha 4 \beta 1, \alpha 5 \beta 1$ en $\alpha 6 \beta 1$, en de expressie van oestrogeen- en progesteronreceptor werd bepaald. E- en P-cadherine werden gedetecteerd in alle monsters en varieerde niet tijdens de cyclus. Wanneer de expressie ervan functioneel betrokken zou zijn bij het cyclische afstoten van het endometrium, dan is het verlies van expressie beperkt tot een heel korte periode. Van de $\beta 1$-integrines was slechts het $\alpha 2 \beta 1$ wisselend aanwezig gedurende de menstruele cyclus. Dit werd niet gevonden in de mid-luteale fase. Er werd geen relatie gevonden tussen de expressie van celadhesiemoleculen en de expressie van oestrogeenreceptor en progesteronreceptor. Omdat de cadherines en de $\beta 1$-integrines konden worden aangetoond in endometrium uit de laat-luteale fase, is het aannemelijk dat deze celadhesiemoleculen betrokken kunnen zijn bij de aanhechting aan het peritoneum van endometriumfragmenten, die als gevolg van retrograde menstruatie in de buikholte aanwezig zijn.

Verder wordt de ontwikkeling beschreven van een in vitro model om de interactie te bestuderen tussen endometriumcellen en extracellulaire matrix (ECM). Tevens wordt de expressie van celadhesiemoleculen in endometriumcellen en weefselfragmenten onder in vitro omstandigheden bestudeerd. Endometriumbiopten werden verzameld en werden ofwel gedigesteerd met collagenase type I, ofwel mechanisch gefragmenteerd door middel van dissectie. Amnionvliezen werden ontdaan van hun epitheellaag (gestript). Adhesie van losse cellen en van weefselfragmenten aan deze gestripte amnionvliezen en aan 
objectglaasjes gecoat met ECM componenten werd bestudeerd. Ook werden de steroïdgevoelige carcinoomcellijnen RL95-2 en AN3CA gebruikt. De expressie van $\beta 1$-integrines en cadherines werd beoordeeld met immunohistochemie. Collagenasedigestie van endometriumweefsel leverde vitale losse cellen op. Deze cellen vertoonden geen adhesie aan een van beide kanten van gestripte amnionvliezen en vertoonden geen expressie van celadhesiemoleculen. Mechanisch gefragmenteerde endometriummonsters vertoonden daarentegen adhesie aan beide kanten van gestripte amnionvliezen en immunohistochemische expressie van E- en P-cadherine en van de integrines $\alpha 2 \beta 1, \alpha 3 \beta 1, \alpha 4 \beta 1$, $\alpha 5 \beta 1$ en $\alpha 6 \beta 1$. De carcinoomcellijnen RL95-2 en AN3CA vertoonden snel adhesie aan amnionvliezen en aan objectglaasjes met coating van ECM componenten. Er wordt geconcludeerd dat amnionvliezen na verwijdering van hun epitheellaag bruikbaar zijn om de interactie van endometriumweefsel en extracellulaire matrix zowel functioneel als structureel te bestuderen. Endometriumcellen zijn na collagenase type I digestie minder geschikt om de initiële fase van adhesie te bestuderen ten gevolge van verlies van functionele celadhesiemoleculen. Carcinoomcellijnen kunnen dienen als een in vitro model om celadhesiegedrag te onderzoeken.

Tenslotte wordt adhesie van endometriumweefsel aan peritoneum bestudeerd, gebruikmakend van intacte amnionviliezen als een in vitro model. Mechanisch gedissecteerde weefselfragmenten van endometriumbiopten zijn gekweekt op beide kanten van intacte amnionvliezen. Ook de carcinoomcellijnen RL95-2 en AN3CA zijn gebruikt. Peritoneum en amnion waren vergelijkbaar wat betreft de expressie van cytokeratines in de epitheelbekleding en de extracellulaire matrixcomponenten. De endometriumfragmenten vertoonden geen adhesie aan de intacte epitheliale kant van het amnionvlies, terwijl adhesie wel optrad aan de niet-epitheliale kant. De carcinoomcellijnen RL95-2 en AN3CA vertoonden adhesie aan beide kanten van het amnionvlies. Er wordt geconcludeerd dat een intacte epitheellaag adhesie voorkomt van endometriumfragmenten aan de extracellulaire matrix van amnionvliezen in vitro. Een intacte epitheellaag kan een belangrijk afweermechanisme zijn in de preventie van adhesie van retrograad gemenstrueerde endometriumfragmenten aan het peritoneum.

Toekomstig onderzoek zou zich dienen te richten op het beïnvloeden van het adhesieproces, bijvoorbeeld door specifieke remming van de functie van celadhesiemoleculen op eiwitniveau, gebruikmakend van antilichamen. Verder dient het gericht te worden op de rol van intact epitheel in het voorkomen van adhesie van endometriumfragmenten aan het peritoneum. 



\section{Curriculum Vitae}

1960 Geboren in de Sint Elisabethkliniek/Vroedvrouwenschool te Heerlen

1972-1978 Gymnasium $\beta$, Jeanne d'Arclyceum te Maastricht

1978-1984 Studie geneeskunde, Rijksuniversiteit Limburg te Maastricht

20-7-1984 Artsexamen

1984 Arts-assistent afdeling longziekten, de Weverziekenhuis, Heerlen

1984-1985 Volontair onderzoek: Evaluatie van twee jaar urodynamisch onderzoek bij vrouwen met incontinentieklachten

1985-1987 Arts-assistent gynaecologie, Sint Elisabethkliniek / Vroedvrouwen-school, Heerlen

1987-1992 Opleiding tot gynaecoloog

1987-1989 Sint Josephziekenhuis Eindhoven opleider: Dr J.H.J.M. Meuwissen

$1990 \quad$ Academisch Ziekenhuis Utrecht opleider: Prof. Dr A.A. Haspels

1991 Sint Josephziekenhuis Veldhoven opleider: Dr J.H.J.M. Meuwissen/Dr H.A.M. Brölmann

1-1-1992 Inschrijving in het specialistenregister voor het specialisme verloskunde en gynaecologie

vanaf

1-4-1992 Gynaecoloog, Academisch Ziekenhuis Maastricht 



\section{List of publications}

\section{Articles}

Gladdines MM, Ackermans MT, Everaerts FM, van der Linden PJQ, Vader HL, Wiegerinck MAHM. Analysis of the aqueous phase of human cervical mucus by reversed-phase high performance liquid chromatography and capillary isotachophoresis. Journal of Chromatography $1988 ; 431: 317-325$.

van der Linden PJQ, Wiegerinck MAHM. Het stompe buiktrauma in de zwangerschap; autogordels vast en zeker? Klinische les. Ned Tijdschr Geneeskd $1989 ; 133: 1153-1156$.

Roumen FJME, de Leeuw JW, van der Linden PJQ, Pannebakker MAG. Non-Hodgkin lymphoma of the puerperal uterus. Obstet Gynecol 1990; 75: 527-529.

van der Linden PJQ, Heintz APM. Zwangerschap in een rudimentaire uterushoorn. Ned Tijdschr Obstet Gynaecol 1991; 104: 59-61.

van der Linden PJQ, Kets M, Gimpel JA, Wiegerinck MAHM. Cyclic changes in the concentration of glucose and fructose in human cervical mucus. Fertil Steril 1992; 57: 573-577.

van der Linden PJQ, Nan PM, te Velde ER, van Kooy RJ. Retrograde ejaculation; successful treatment with artificial insemination. Obstet Gynecol 1992; 79: 126-128.

van der Linden PJQ, Wiegerinck MAHM. Trauma en zwangerschap. De Vrouwelijke Patiënt 1992; 5: 22-26.

Brölmann HAM, Pernet PM, van der Linden PJQ, de Graaff J. Diathermische excisie met een metalen lus als behandeling van Cervicale Intraepitheliale Neoplasie; korte termijn resultaten bij 154 patiënten. Ned Tijdschr Geneeskd 1992; 136: 2227-2231. 
Brölmann HAM, van der Linden $\mathrm{PJQ}$, Bongers MY, Moret $\mathbb{E}$, Meuwissen JHJM. Echoscopische diagnostiek van endometriumafwijkingen: de samenhang met de histologische uitslag bij 112 patiënten. Ned Tijdschr Geneeskd 1993; 137: $1823-1827$.

Evers JLH, Dunselman GAJ, Land JA, Bouckaert PXJM, van der Linden PJQ. Diagnostic d'endométriose après un traitement apparemment efficace: formation de novo, ré-apparition ou persistance? Ref Gynecol Obstet 1993; 1: 434439 .

Evers JLH, Dunselman GAJ, van der Linden PJQ. Markers for endometriosis. Baill Clin Obstet Gynecol 1993; 7: 715-739.

van der Linden PJQ, de Goeij AFPM, Dunselman GAJ, van der Linden EPM, Ramaekers FCS, Evers JLH. Expression of integrins and E-cadherin in cells from menstrual effluent, endometrium, peritoneal fluid, peritoneum and endometriosis. Fertil Steril 1994; 61: 85-90.

van der Linden PJQ, de Goeij AFPM, Dunselman GAJ, Arends JW, Evers JLH. P-cadherin expression in human endometrium and endometriosis. Gynaecol Obstet Invest 1994; 38: 183-185.

van der Linden PJQ. The scientific foundations of endometriosis theories: how hard are the data? In: Evers JLH, Vermeiden JPW. ed. Endometriosis and fertility 1994: what can we expect?, 7-12, ESHRE Ferring, Malmoe Sweden, 1994.

van der Linden PJQ, Evers JLH, Dunselman GAJ. Endometriosis externa: pathogenese. Scoop 1994; 1: 26-28.

van der Linden PJQ, de Goeij AFPM, Dunselman GAJ, Erkens HWH, Evers $\mathrm{JLH}$. Expression of cadherins and integrins in human endometrium throughout the menstrual cycle. Fertil Steril 1995; 63: 1210-1216.

van der Linden PJQ, Dunselman GAJ, de Goeij AFPM, van der Linden EPM, Evers JLH, Ramaekers FCS. Epithellial cells in peritoneal fluid: of endometrial origin? Am J Obstet Gynecol 1995; 173: 566-570.

van der Linden PJQ, de Goeij AFPM, Dunselman GAJ, Erkens HWH, Evers $\mathrm{JLH}$. Endometrial cell adhesion in an in vitro model using intact amniotic membranes. Fertil Steril 1995, in press. 
van der Linden PJQ. Cell adhesion, cell adhesion molecules and their functional role in the human endometrium. Early pregnancy: biology and medicine 1995 , in press.

van der Linden PJQ. Theories on the pathogenesis of endometriosis. Hum Reprod 1995, accepted for publication

van der Linden PJQ, de Goeij AFPM, Dunselman GAJ, Erkens HWH, Evers JLH. Amniotic membrane as an in vitro model for endometrium-extracellular matrix interactions. Submitted for publication.

\section{Abstracts}

van Geelen JM, Hasaart THM, van der Linden PJQ, de Haan J. Assesing the diagnostic value of history taking in the evaluation of urinary incontinence. Proc. $3 d$ joint meeting International continence society/ 16th annual meeting urodynamics society, Boston 1986.

van Geelen JM, Hasaart THM, van der Linden PJQ, de Haan J. Betekenis van urodynamisch onderzoek bij de diagnostiek en behandeling van incontinentie. Ned Tijdschr Geneeskd 1987; 37: 1641.

van der Linden PJQ, Nan PM, te Velde ER, van Kooy RJ. Retrograde ejaculatie; succesvolle behandeling met kunstmatige inseminatie. Ned Tijdschr Obstet Gynaecol 1992; 105: 111 en Ned Tijdschr Geneeskd 1992; 136: 1136.

van der Linden PJQ, de Goeij AFPM, Dunselman GAJ, van der Linden EPM, Ramaekers FCS, Evers JLH. Immunohistochemistry of E-cadherin and integrins in samples from human endometrium, menstrual effluent, peritoneal fluid and endometriosis. Abstract. Cell adhesion. Regulation and clinical prospects. Amsterdam, 13-16 October 1993.

wan der Linden PJQ, Dunselman GAJ, de Goeij AFPM, Evers JLH. Immunohistochemistry of epithelial cells from peritoneal fluid, menstrual effluent, endometrium, peritoneum and endometriotic lesions. Abstract. $4^{\text {th }}$ World congress on endometriosis, Salvador Bahia, Brasil, 25-28 mei 1994.

Evers JLH, Dunselman GAJ, van der Linden PJQ. New markers for endometriosis. Abstract. $4^{\text {th }}$ World congress on endometriosis, Salvador Bahia, Brasil, 25-28 mei 1994. 
Evers JLH, Dunselman GAJ, Land JA, Bouckaert PXJM, van der Linden PJQ. Management of recurrent endometriosis. Abstract. $4^{\text {th }}$ World congress on endometriosis, Salvador Bahia, Brasil, 25-28 mei 1994.

van der Linden PJQ. The scientific foundations of endometriosis theories: how hard are the data? Hum Reprod 1994; $9: 11$. Abstract. $X^{\text {th }}$ Annual meeting of ESHRE, Brussel, 25-29 juni 1994.

van der Linden PJQ, de Goeij AFPM, Dunselman GAJ, Erkens HWH, Evers ЛLH. Cyclic cadherin and integrin expression in human endometrium. Fertil Steril 1994; 62: S81. Abstract. 50 ${ }^{\text {th }}$ Annual meeting of the American Fertility Society, San Antonio, USA, 5-10 november 1994.

Dunselman GAJ, van der Linden PJQ. Endometriosis-associated subfertility: a survey of treatment preferences. Abstract. XIth Annual meeting of ESHRE, Hamburg, 28 juni-1 juli 1995.

van der Linden PJQ, de Goeij AFPM, Dunselman GAJ, Erkens HWH, Evers JLH. Endometrium-extracellular matrix interactions in an in vitro model using amniotic membranes. Abstract. XI ${ }^{\text {th }}$ Annual meeting of ESHRE, Hamburg, 28 juni-1 juli 1995.

Dunselman GAJ, van der Linden PJQ, de Goeij AFPM, Evers JLH. Epithelial markers and endometriosis, an immunohistochemical study. Abstract. $\mathrm{XV}^{\text {th }}$ World congress on Fertility and Sterility, Montpellier, 17-22 september 1995.

Dunselman GAJ, van der Linden PJQ. Treatment preference in endometriosis associated subfertility. Abstract. XVth ${ }^{\text {th }}$ World congress on Fertility and Sterility, Montpellier, 17-22 september 1995. 


\section{Dankwoord}

Dit proefschrift werd bewerkt binnen de afdeling Obstetrie en Gynaecologie van het Academisch ziekenhuis Maastricht (hoofd: Prof. dr J. de Haan). Het bewerken van de weefsels en de cellen vond vooral plaats binnen de afdeling Pathologie van het Academisch ziekenhuis Maastricht (hoofd: Prof dr J.W. Arends), in het bijzonder het laboratorium voor immunohistochemie.

Aan de tot standkoming ervan werd door velen een bijdrage geleverd en hun hulp was onontbeerlijk. Ik wil een ieder die op welke wijze erbij betrokken was zeer hartelijk danken. Zonder iemand te kort te willen doen noem ik een aantal personen in het bijzonder.

De promotor, Prof. dr J.L.H. Evers. Beste Hans, aan het einde van mijn opleiding tot gynaecoloog bood jij me de gelegenheid om naar Maastricht te komen om promotieonderzoek te komen verrichten en mij verder te verdiepen in de reproductieve endocrinologie en fertiliteit. Ik dank je voor het in mij gestelde vertrouwen en je inzet bij de begeleiding van het onderzoek.

De co-promotor, Dr A.F.P.M. de Goeij. "Ome" Ton, dank voor je geweldige begeleiding. De wijze waarop jij een jonge onderzoeker weet te sturen en te stimuleren, met intact laten van de waarde van de persoon in kwestie, mag uniek. genoemd worden. Het zal niet altijd even gemakkelijk zijn geweest. Ik verheug me op een nog langdurige samenwerking.

De co-promotor, Dr G.A.J. Dunselman. Beste Gerard, je opmerking van 26 mei 1988 heeft er dan toch toegeleid dat het rode boek een, naar ik hoop, waardig vervolg heeft gekregen. Zeer veel dank voor het delen van je ideeën omtrent het ontstaan van de "gevreesde ziekte". Ik denk met veel plezier terug aan lange discussies over her "how".

De leden van de beoordelingscommissie, onder voorzitterschap van Prof. dr J.W. Arends, dank ik voor de wijze waarop zij het manuscript hebben getoetst en voor de opmerkingen die ik mocht ontvangen.

De pathologen, assistenten en overige medewerkers van de afdeling pathologie, gedoogden mij als beun op hun afdeling. Ik dank jullie voor de getoonde belangstelling en hulp wanneer dat nodig was.

Mw. E.P.M. van der Linden. Beste Edith, zonder jouw inzet en ervaring had de immunohistochemie er heel anders uitgezien. Ik denk niet dat ik een echte "coupeboer" ben geworden, maar ik heb mijn best gedaan. 
Mw. H.W.H. Erkens. Beste Heleen, dank voor het zo accuraat opzetten en verzorgen van het kweekwerk.

Mw. L.J.H. Bouchet. Beste Liesbeth, in korte tijd heb je een lopend onderzoek moeten overnemen en dat deed je met verve. Door jouw enthousiasme zal het project nog zeker voortbloeien.

Don Surtel en Dr Roel Kuyer stelde een deel van de kweekfaciliteiten van het orhopedisch researchlaboratorium ter beschikking, waarvoor dank.

Dr Adriaan de Bruïne leerde de beginselen van de fotomicroscoop. Dr Jack Cleutjens hielp met zijn kennis op het gebied van de basaalmembraan en bewerking van de amnionvliezen.

Gynaecologen, assistenten en andere collega medewerkers van de afdeling obstetrie en gynaecologie. Bedankt voor de belangstelling en aanmoedigingen bij het verrichten van het onderzoek. In het bijzonder dank ik alle medewerkers van het IVF-team, waarvan ik in de afgelopen jaren onder andere deel mocht uitmaken.

Medewerkers van de Audiovisuele dienst van het AZM, in het bijzonder Hans Patelski, waren behulpzaam bij het vervaardigen van de "plaatjes".

Mijn ouders dank ik voor hun steun en niet aflatende belangstelling.

Lieve Mirjam, dat ik jou hier zou bedanken, wil je niet en het zou ook afbreuk doen aan hetgeen je voor mij betekent. Weet, dat het zonder jou niet gelukt was.

Lieve Joep, in het boekje van papa zit helaas geen piepje en het kan ook niet mee in bad, althans niet vaker dan één keer. Ik hoop dat je ooit zult waarderen waarom dit nodig was. Papa heeft nu weer meer tijd voor jou. 
Alle hoofdstukken in dit proefschrift, die eerder verschenen als artikel in een wetenschappelijk tijdschrift, zijn herdrukt met toestemming van de uitgevers.

Het in dit proefschrift beschreven onderzoek werd mede mogelijk gemaakt door een research grant van Organon International.

De publikatie van dit proefschrift werd mede mogelijk gemaakt door:

Drs J.H. van der Linden

Ciba Geigy B.V.

Organon Nederland B.V.

Zeneca Farma

Ferring B.V.

Novo Nordisk Farma B.V.

Pfizer B.V.

Sanofi Winthrop V.O.F.

Schering Nederland B.V.

Wyeth Laboratoria B.V.

Nourypharma B.V. 